\title{
BRUNA PRATI
}

Expressão de genes de vias de reparo de dano ao DNA em células infectadas por papilomavírus humano (HPV)

Dissertação apresentada ao Programa de Pós-Graduação em Microbiologia do Instituto de Ciências Biomédicas da Universidade de São Paulo, para obtenção do Título de Mestre em Ciências. 


\section{BRUNA PRATI}

\section{Expressão de genes de vias de reparo de dano ao DNA em células infectadas por papilomavírus humano (HPV)}

Dissertação apresentada ao Programa de Pós-Graduação em Microbiologia do Instituto de Ciências Biomédicas da Universidade de São Paulo, para obtenção do Título de Mestre em Ciências.

Área de concentração: Microbiologia

Orientador: Prof. Dr. Enrique Mario Boccardo Pierulivo

Versão original 
DADOS DE CATALOGAÇÃO NA PUBLICAÇÃO (CIP)

Serviço de Biblioteca e Informação Biomédica do Instituto de Ciências Biomédicas da Universidade de São Paulo

reprodução não autorizada pelo autor

Prati, Bruna.

Expressão de genes de vias de reparo de dano ao DNA em células infectadas por papilomavírus humano (HPV) / Bruna Prati. -- São Paulo, 2014.

Orientador: Prof. Dr. Enrique Mario Boccardo Pierulivo.

Dissertação (Mestrado) - Universidade de São Paulo. Instituto de Ciências Biomédicas. Departamento de Microbiologia. Área de concentração: Microbiologia. Linha de pesquisa: Oncovirologia.

Versão do título para o inglês: Gene expression pathways to DNA damage repair in cells infected with human papillomavirus (HPV).

1. HPV 2. Câncer do colo do útero 3. Reparo do DNA 4. expressão gênica 5. I. Pierulivo, Prof. Dr. Enrique Mario Boccardo

II. Universidade de São Paulo. Instituto de Ciências Biomédicas.

Programa de Pós-Graduação em Microbiologia III. Título. 
Candidato(a):

Título da Dissertação:

Orientador(a):
Bruna Prati.

Expressāo de genes de vias de reparo de dano ao DNA em células infectadas por papilomavirus humano (HPV).

A Comissāo Julgadora dos trabalhos de Defesa da Dissertaçāo de Mestrado, em sessão pública realizada a .................., considerou
( ) Aprovado(a)
( ) Reprovado(a)

Examinador(a): Assinatura:

Nome:

Instituiçăo:

Examinador(a): Assinatura:

Nome:

Instituição:

Presidente: Assinatura:

Nome:

Instituiçāo: 


\section{CERTIFICADO DE ISENÇÃO}

Certificamos que o Protocolo CEP-ICB No 479/11 referente ao projeto intitulado: "Estudo da expressão de genes de mecanismo de reparo de dano de DNA em células infectadas por papilomavirus bumano (HPV)" sob a responsabilidade de Bruna Prati, foi analisado na presente data pela CEUA - COMISSÃO DE ÉTICA NO USO DE ANIMAIS e pela CEPSH- COMISSÃo de ÉtTICA EM PESQUTSA COM SERES HUMANOS, tendo sido deliberado que o referido projeto não utilizará animais que estejam sob a égide da lei 11.794 de 8 de outubro de 2008, nem envolverá procedimentos regulados pela Resolução CONEP n¹96 de 1996.

São Paulo, 20 de setembro de 2011.

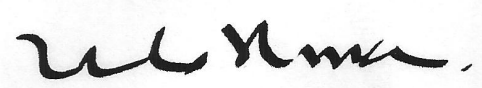

Prof. Dr. Wothan TAVARES DE LIMA Coordenador da CEUA - ICB/USP

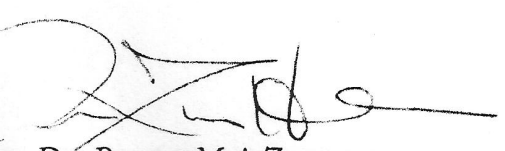

PROF. DR. PAOLO M.A ZANOTTO Coordenador da CEPsh - ICB/USP 
`A minha mãe (Suely) e ao meu pai (Maurizio): por serem exemplos de caráter, dedicação e amizade. Obrigada pela compreensão, confiança e incentivos incondicionais, sem os quais eu jamais poderia alcançar os meus objetivos. 


\section{AGRADECIMENTOS}

Agradeço ao meu namorado, Leonardo, por entender e me ajudar a superar as dificuldades da pesquisa. E escutar cada reclamação da minha rotina toda noite antes de dormir.

Aos meus irmãos e cunhados Julia, Marcelo, Ricardo e Vivian que me apoiaram e compreenderam, a importância da pesquisa na minha vida, mesmo sabendo que poderiam deixar de estar comigo em algumas datas especiais de nossa família.

A minha linda família pelos domingos juntos

Ao meu orientador, Enrique Boccardo, por ter confiado e dado oportunidade de trabalhar sob seus cuidados com suportes indispensáveis à execução do meu trabalho para que eu superasse meus limites pessoais e acadêmicos.

Aos meus colegas e amigos do Laboratório Mirian, Bia, Claudia, Tatiane, Walason, Vanesca, Alice, Lizete e Gustavo que me fizeram aprender muito sobre a vida, e me ajudaram a superar os imprevistos com boas risadas. Em especial a Mirian pela disposição e ajuda com as análises dos resultados.

Ao Prof. Carlos Frederico Martins Menck, e todos do seu laboratório pela ajuda em especial a Veridiana, Clarissa e Luciana.

A todos os professores, funcionários e colegas da pós-graduação por estarem presentes na minha vida todos os dias nesses últimos anos.

A memória de meus queridos avós (Dolores, Paulo, Luisa e Luis) que estariam orgulhosos de mais uma das minhas conquistas. 
"Quanto mais aumenta nosso conhecimento, mais evidente fica nossa ignorância". (John F. Kennedy) 


\section{RESUMO}

Prati B. Expressão de genes de vias de reparo de dano ao DNA em células infectadas por papilomavírus humano (HPV). [dissertação (Mestrado em Microbiologia)]. São Paulo: Instituto de Ciências Biomédicas, Universidade de São Paulo; 2014.

Os papilomavírus humanos (HPV) são vírus de DNA que infectam epitélios em regiões anatômicas específicas. Alguns tipos de HPV, denominados de "alto risco oncogênico", têm associação etiológica com o câncer do colo do útero. Estes vírus expressam dois oncogenes, E6 e E7, que cooperam para imortalizar queratinócitos humanos in vitro, alterando o ciclo celular e o programa de diferenciação destas células. Estes efeitos, por sua vez, promovem o acúmulo de defeitos mitóticos e instabilidade genômica, contribuindo à transformação maligna. Alterações nos sistemas de reparo de dano ao DNA associadas à presença de HPV têm sido descritas em diferentes modelos experimentais. No entanto, até o momento não tem sido analisado de maneira sistemática o efeito do HPV na expressão dos genes envolvidos nestas diferentes vias. No presente estudo, avaliamos de maneira comparativa a expressão de 135 genes envolvidos nas vias de reparo de dano ao DNA em queratinócitos primários humanos (QPH) e em linhagens derivadas de carcinomas do colo do útero positivas ( $\mathrm{SiHa}$ e HeLa) e negativas (C33A) para HPV. Observamos que, quando comparadas aos QPH, as linhagens tumorais apresentaram um grande número de genes diferencialmente expressos. Além disso, quando comparamos as linhagens tumorais HPV positivas com a linhagem HPV negativa (C33A) identificamos 9 genes cuja expressão diferencia as linhagens HPV positivas da linhagem HPV negativa. Os dados de expressão gênica foram confirmados por PCR em tempo real e western-blot. Além disso, foi realizado o silênciamento de dois desses genes, TREX1 e RPA1, nas células tumorais HPV positivas. Os dados obtidos mostram que o silênciamento dos genes RPA1 eTREX1 tem um impacto importante, na viabilidade das linhagens tumorais. Nossos resultados indicam a presença de alterações importantes na expressão de genes envolvidos nas vias de reparo de dano ao DNA em linhagens derivadas de tumores do colo do útero. Além disso, as diferenças no padrão de expressão observadas nos genes associados a estas vias nas diferentes linhagens tumorais sugere que diferentes combinações de alterações podem estar envolvidas na gênese deste tipo tumoral. Por outro lado, a identificação de um grupo de genes com expressão alterada entre as linhagens HPV positivas e a linhagem HPV negativa indica que os mesmos podem ter um papel importante no estabelecimento/progressão de tumores associados à infeção por HPV.

Palavras chave: HPV. Câncer do colo do útero. Reparo do DNA. Expressão gênica. 


\begin{abstract}
Prati B. Expression of DNA damage repair pathways associated genes in cells infected with human papillomavirus (HPV). [dissertation (Masters thesis (Microbiology)] São Paulo: Instituto de Ciências Biomédicas, Universidade de São Paulo; 2014.

The Human papillomaviruses (HPV) are DNA viruses that infect epithelia in specific anatomical regions. Some types of HPV, called "high-risk or oncogenic types" are etiologically associated with cervical cancer. These viruses express two oncogenes $E 6$ and $E 7$, which cooperate to immortalize human keratinocytes in vitro, altering the cell cycle and differentiation program of these cells. These effects, promotes the accumulation of mitotic defects and genomic instability, contributing to malignant transformation. Alterations in the DNA damage repair mechanisms associated with the presence of HPV have been described in different experimental models. However, the effect of HPV on the expression of genes involved in theses pathways has not been systematically analyzed. In the present study, we evaluated in a comparative manner the expression of 135 genes involved in DNA damage repair pathways in primary human keratinocytes (PHK) and HPV-positive (SiHa and HeLa) and HPV-negative (C33A) cervical cancer derived cell lines. We observed that, when compared to the PHK, tumor derived cell lines exhibited a large number of differentially expressed genes. Furthermore, when we compared HPV-positive tumor cell lines with the HPV-negative cell line (C33A) we identified 9 differentialy expressed genes. Gene expression data were confirmed by real-time PCR and western-blot. Moreover, the expression of two selected genes, RPA1 and TREX1, was silenced in tumor cells using lentiviral vectors expressing specific shRNA. We observed that RPA1 and TREX1 silencing has important effects on tumor cells viability. Our results support the presence of significant changes in the expression of genes involved in DNA damage repair pathways in cervical cancer derived cell lines. Furthermore, the differences in the expression of genes associated with these pathways in the different tumor lines suggests that different combinations of alterations may be involved in the genesis of this tumor type. On the other hand, the identification of a group of genes with altered expression between HPV-positive and HPV-negative cell lines indicates that these genes may play an important role in HPV-associated tumor establishment/progression.
\end{abstract}

Keywords: HPV. Cervical cancer. DNA repair. Gene expression. 


\section{LISTA DE FIGURAS}

Figura 1 - O genoma do HPV e seu ciclo de vida.

Figura 2 - Representação esquemática de vias de sinalização ativadas em resposta ao dano ao DNA. .22

Figura 3 - O ciclo do HPV e a progressão do câncer do colo do útero. .23

Figura 4 - Análise da integridade do RNA.

Figura 5 - Comparação da expressão de genes envolvidos nas vias de sinalização de dano ao DNA e nas vias de reparo de dano ao DNA entre queratinócitos normais e linhagens derivadas de cânceres de colo de útero.

Figura 6 - Agrupamento das amostras em função do padrão de expressão de 84 genes envolvidos nas vias de sinalização de dano ao DNA e 84 genes envolvidos no reparo de dano ao DNA

Figura 7 - Comparação da expressão de genes de vias de reparo de dano ao DNA entre linhagens de câncer de colo de útero HPV negativa (C33A) e positivas (SiHa e HeLa)......

Figura 8 - Controle da reação de síntese de cDNA.

Figura 9 - Análise dos níveis de expressão relativa de RNAm para o gene TREX1 nas linhagens de QPH, SiHa, HeLa e C33A. .50

Figura 10 - Análise dos níveis de expressão relativa de RNAm correspondente ao gene TREX1 em culturas organotípicas de QPH pLXSN, QPH 16E6E7, QPH pBABE, QPH 11E6E7.

Figura 11 - Curva de dissociação das amostras de cultura organotípicas QPH pLXSN, QPH 16E6E7, QPH pBABE, QPH 11E6E7 para o gene TREX1.

Figura 12 - Análise por eletroforese da reação de qPCR para o gene TREX1 em amostras de culturas organotípicas de QPH transduzidos com os vetores $\mathrm{pLXSN}$, HPV16 E6E7, pBABE e HPV11 E6E7, e de culturas em monocamadas de QPH e $\mathrm{SiHa}$

Figura 13 - Análise dos níveis de expressão relativa de RNAm para o gene RAD51 nas linhagens de QPH, SiHa, HeLa e C33A.

Figura 14: Determinação dos níveis das proteínas CHEK2, FEN1, LIG1, MAP2K6, MRE11A, PCNA, PNK, RAD51, RAD9, RPA1, SMC1A e TREX1 por western blot 
Figura 15 - Determinação dos níveis das proteínas RPA1 e TREX1 por western blot. 60

Figura 16 - Determinação do efeito do silênciamento de RPA1 e TREX1 na viabilidade da linhagem SiHa.

Figura 17 - Determinação do efeito do silênciamento de RPA1 e TREX1 na viabilidade das linhagens SiHa e HeLa. .63 


\section{LISTA DE TABELAS}

Tabela 1 - Sequência dos oligonucleotídeos utilizados para quantificação do mRNA dos genes selecionados.

Tabela 2 - Nome e alteração relativa no nível de expressão (fold: amostra/controle) dos 10 genes envolvidos na sinalização de dano ao DNA diferencialmente expressos entre as linhagens de câncer do colo do útero e QPH (controle).

Tabela 3 - Nome e alteração relativa no nível de expressão (fold: amostra/controle) dos 9 genes envolvidos na sinalização de reparo de dano ao DNA diferencialmente expressos entre linhagens de câncer do colo do útero e QPH (controle).

Tabela 4 - Nome e alteração relativa no nível de expressão (fold: amostra/controle) dos 4 genes envolvidos na sinalização de dano ao DNA diferencialmente expressos entre as linhagens de derivadas de tumores do cólo do útero HPV positivas e a linhagem HPV negativa (controle).

Tabela 5 - Nome e alteração relativa no nível de expressão (fold: amostra/controle) dos 7 genes envolvidos na sinalização de reparo do dano ao DNA diferencialmente expressos entre as linhagens derivadas de tumores do cólo do útero de câncer HPV positivas e a linhagem HPV negativa (controle). 


\section{LISTA DE ABREVEATURAS E SIGLAS}

ATM - Ataxia telangiectasia mutated

ATR - Ataxia telangiectasia and Rad3 related

BER - Base excision repair

CDK - Cyclin-dependent kinase

CHEK1 - Checkpoint kinase 1 homolog (S. cerevisiae)

CHEK2 - Checkpoint kinase 2 homolog (S. cerevisiae)

DDR - DNA damage response

DNA - Ácido desoxirribonucléico

DSB - Double strand break

GGR - Global genome repair

HPV - Papilomavírus humano

MMR - Mismatch repair

NER - Nucleotide excision repair

NHEJ - Non-homologous end joining

ORF- Open reading frame (Janela aberta de leitura)

PCNA - Proliferatin cell nuclear antigen

PCR - Reação em cadeia da polimerase

qPCR - Reação em cadeia da polimerase em tempo real

QPH - Queratinócitos primários humanos

RNA - Ácido ribonucléico

RNAm - Ácido ribonucléico mensageiro

RT-PCR - Reação da transciptase reversa seguida da reação em cadeia da polimerase

SSB - Single strand break

TP53 - Tumor protein p53 


\section{SUMÁRIO}

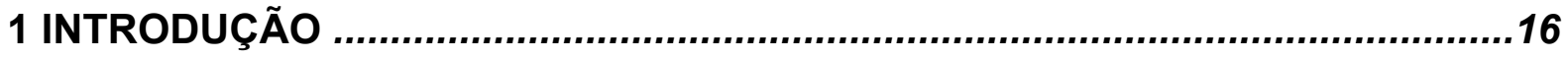

1.10 Papilomavírus Humano...............................................................................16

1.2 O HPV e o Câncer ..........................................................................................18

1.3 Mecanismo de reparo do dano ao DNA.......................................................20

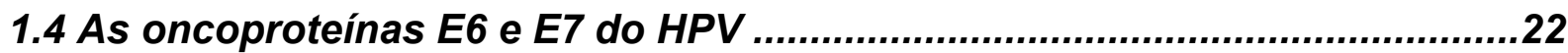

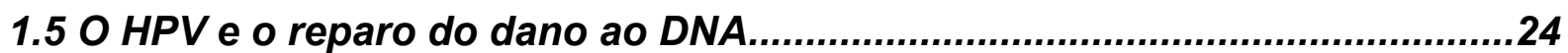

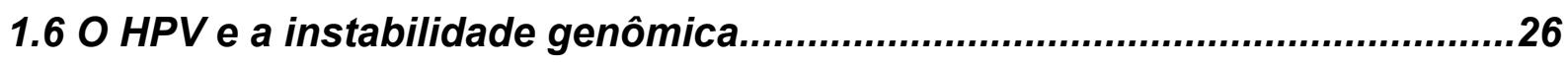

2 OBJETIVO .....................................................................................................29

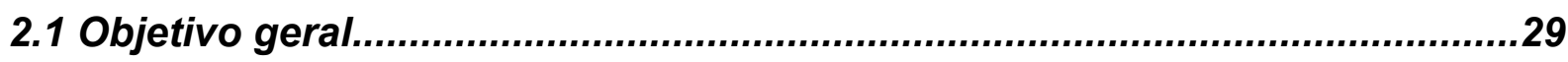

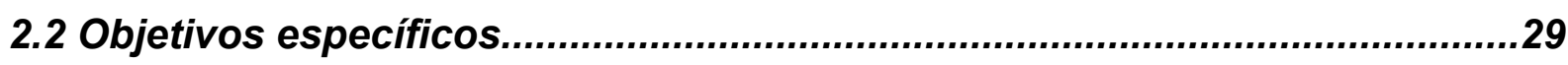

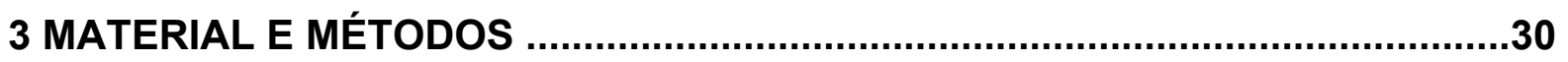

3.1 Cultura de células em monocamada................................................................30

3.1.1 Linhagens celulares derivadas de tumores do colo do útero..........................30

3.1.2 Queratinócitos e vetores retrovirais.................................................. 30

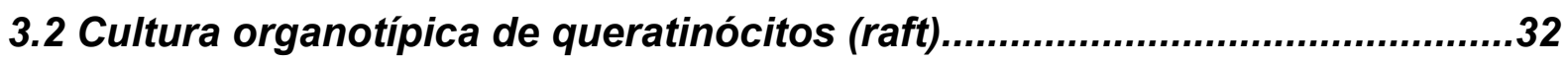

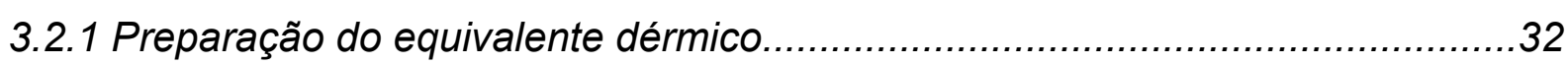

3.2.2 Montagem da cultura organotípica....................................................... 32

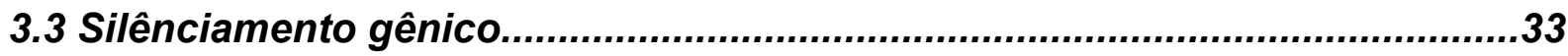

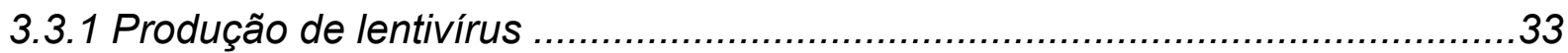

3.3.2 Silênciamento de genes específicos nas linhagens transformadas por

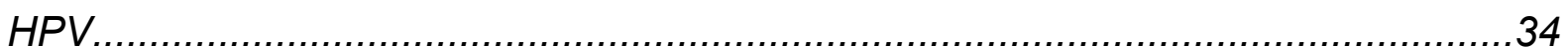

3.4 Ensaio de Viabilidade Celular....................................................................34

3.5 Análise da expressão de genes envolvidos nas vias de reparo do dano ao

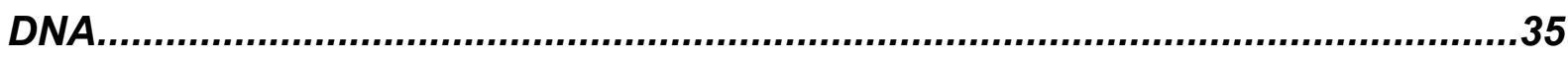

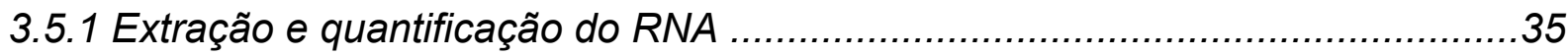

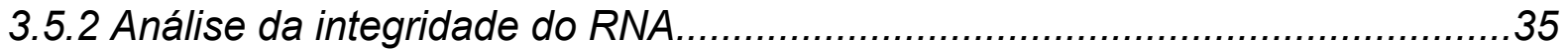

3.5.3 Controle da contaminação por DNA genômico..............................................35

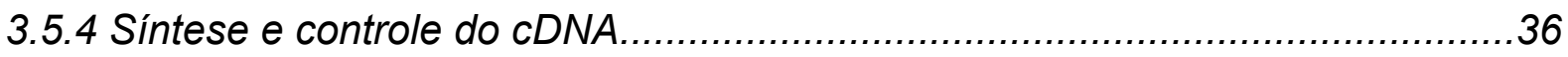

3.5.5 Análise da expressão gênica utilizando arrays comerciais.............................36

3.5.6 Validação dos dados da expressão gênica por qPCR .................................38

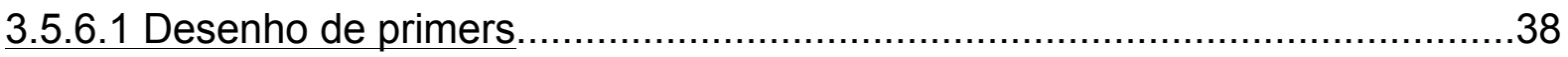


3.6 Análise da expressão de proteínas envolvidas nas vias de reparo de dano ao DNA.

3.6.1 Extração de proteínas.

3.6.2 Western blot 40

4 RESULTADOS. .42

4.1 Análise da expressão de genes das vias de reparo de dano ao DNA em células normais e linhagens derivadas de tumores do colo do útero. 42

4.2 Análise da expressão de genes das vias de reparo de dano ao DNA em linhagens derivadas de tumores do colo do útero. .46

4.3 Validação dos dados de expressão gênica por PCR em tempo real. 48

4.4 Validação dos dados de expressão gênica por análise de proteínas. 54 4.5 Determinação do efeito de proteínas selecionadas na viabilidade celular. .59

5 DISCUSSÃO. .64

6 CONCLUSÕES. .73

REFERÊNCIAS. .74 


\section{INTRODUÇÃO}

\subsection{O Papilomavírus Humano}

Os papilomavírus humanos (HPV) pertencem à família Papillomaviridae. São vírus não envelopados com capsídeo icosaédrico com um diâmetro de 50 a $60 \mathrm{~nm}$. O seu genoma é composto por DNA de fita dupla circular e contém cerca de 8.000 pares de bases. Esses vírus apresentam tropismo específico por epitélios escamosos estratificados da pele e mucosas e dependem da diferenciação epitelial para a conclusão do seu ciclo de vida (Doorbar, 2005; McMurray et al., 2001).

Os HPV são classificados em cinco gêneros baseados na análise de sua sequência de DNA. Os diferentes tipos de HPV apresentam diferentes características em seus ciclos biológicos e estão associados a diferentes patologias. As infecções por HPV podem levar a uma variedade de proliferações benignas como verrugas, cistos epidérmicos, neoplasias intraepiteliais, papilomas anogenitais, orolaríngeos ou faríngeos e outros tipos de hiperqueratoses. Até o momento foram descritos aproximadamente 200 tipos de HPV (Bosch, Munoz, 2002). Os HPV que infectam a mucosa anogenital são classificados como de baixo ou alto risco oncogênico em função ao tipo de lesão associado à infeç̧ão. Os HPV de baixo risco, por exemplo, HPV6 e HPV11, estão associados a lesões de baixo grau e verrugas genitais. Por outro lado, os HPV de alto risco, por exemplo, HPV16 e HPV18, estão associados a lesões de alto grau e ao câncer do colo do útero. Além disso, os HPV de alto risco estão associados a uma porcentagem significativa de carcinomas anais, carcinomas de vulva, carcinomas de pênis e carinomas da orofaringe (IARC, 2007).

O genoma do HPV pode ser dividido em três regiões funcionais: (i) uma região reguladora não codificante, denominada região reguladora upstream (URR) ou região controladora longa (LCR), que modula a replicação do DNA viral e a transcrição de genes; (ii) uma região que contém os genes precoces de HPV (E1, E2, E4, E5, E6, E7), que codificam para proteínas envolvidas na persistência do genoma, na replicação, na transcrição viral e na regulação da proliferação celular; e 
(iii) uma região tardia compostas de dois genes, L1 e L2, que codificam para a proteína principal e a proteína secundária do capsídeo, respectivamente (Figura 1-A) (Howley, Lowy, 2007; McMurray et al., 2001).

A transmissão do vírus se dá por contato direto com a pele ou mucosa infectada. Os vírus penetram no epitélio através microabrasões e infectam células epiteliais da camada basal através da interação das proteínas do capsídeo viral com receptores específicos da superfície celular. Uma vez no interior das células da camada basal do epitélio, o genoma do HPV se estabelece na forma epissomal e replica-se simultaneamente com o DNA celular.

As proteínas codificadas pelos genes precoces (E1, E2, E4 e E5) são expressas, em baixa concentração nas células basais do epitélio, a fim de garantir a evasão do sistema imune e a manutenção da replicação do genoma viral. As proteínas codificadas pelos genes precoces E6 e E7 do HPV, são produzidas também em baixa concentração nas camadas basal do epitélio sob regulação do gene E2. O vírus necessita da maquinaria da célula para a replicação do seu DNA. Assim, as proteínas E6 e E7 cooperam para criar um ambiente favorável para a síntese de DNA nas células das camadas suprabasais do epitélio, levando a célula infectada a progredir no ciclo celular. Nas camadas mais superficiais do epitélio são expressas as proteínas estruturais L1 e L2, formando as partículas virais maduras que são liberadas por descamação celular (Figura 1-B). De fato, os promotores virais são regulados por fatores celulares presentes apenas em algumas etapas do processo de diferenciação epitelial (Doorbar, 2005; Howley, Lowy, 2007; Wilson et al., 2002). 
A)

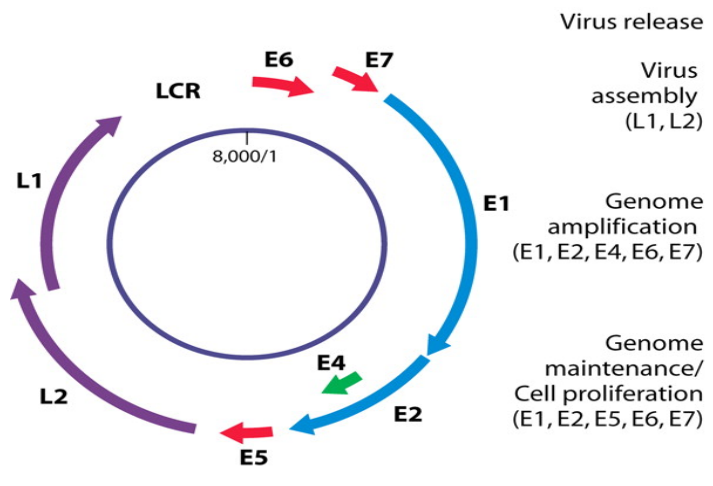
maintenance

B)
Genome

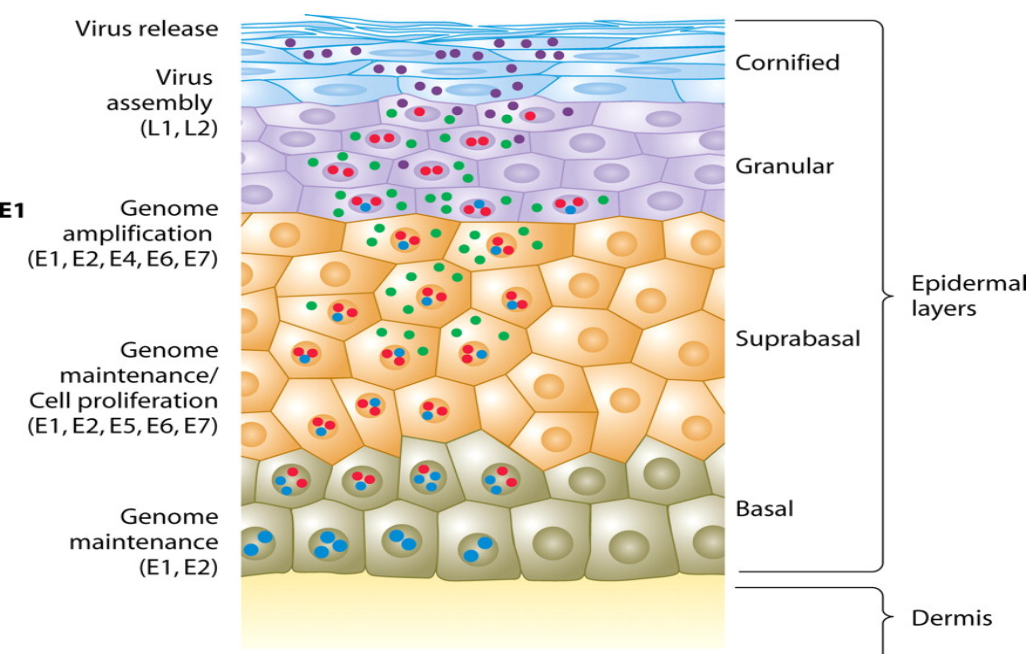

Figura 1 - O genoma do HPV e seu ciclo de vida. A) Representação esquemática do genoma do HPV e suas regiões funcionais: região controladora longa (LCR) e as ORFs que codificam as diferentes proteínas virais (precoces e tardias). B) O ciclo de vida do HPV: a expressão das proteínas virais e suas funções ao longo da diferenciação do epitélio estratificado escamoso.

Fonte: (Lazarczyk et al., 2009)

\subsection{O HPV e o Câncer}

No final da década de 1970, os dados epidemiológicos disponíveis sobre o padrão de incidência do câncer do colo do útero sugeriram sua associação a um agente sexualmente transmissível. Isto levou a que Harald zur Hausen propusesse a existência de uma associação entre a infecção por HPV e o câncer do colo do útero. Nos anos seguintes, zur Hausen e seu grupo mostraram a presença do DNA de de tipos específicos de HPV em amostras tumorais (Boshart et al., 1984; Durst et al., 1983). Em 2008, Harald zur Hausen recebeu o Premio Nóbel de Medicina pela sua contribuição ao estabelecimento do vínculo etiológico entre o HPV e o câncer do colo do útero. Essa observação levou muitos pesquisadores estudarem a história natural da infecção por HPV, contribuindo para a compreensão dos mecanismos de carcinogênese do colo do útero, e de outros tipos de câncer relacionados a este vírus. Estes esforços estabeleceram as bases teóricas e metodológicas para o desenvolvimento de vacinas profiláticas contra a infecção pelos principais tipos de HPV associados ao câncer.

Estima-se que aproximadamente 291 milhões de mulheres estão infectadas por HPV genitais no mundo todo. A cada ano, cerca de 500 mil novos casos de câncer do colo do útero são diagnosticados e aproximadamente, 270 mil mulheres morrem 
por causa desta doença. É importante salientar que a grande maioria dos casos $(86 \%)$ e das mortes (88\%) ocorrem em países em desenvolvimento. Além disso, aproximadamente $90 \%$ dos cânceres anais e uma proporção relevante de outros carcinomas (orofaringe, pênis, vagina e vulva) são atribuídos à infecção por este vírus. Em conjunto, a infecção por HPV é responsável por $5.2 \%$ dos tumores que afetam a população humana no mundo (Tota et al., 2011).

No Brasil, o câncer do colo do útero é o terceiro mais frequente na população feminina, atrás do câncer de mama e o câncer colorretal, e a quarta causa de morte em mulheres por câncer (Instituto Nacional do Câncer, 2014). A infecção pelo HPV é um fator necessário, mas não suficiente, para o desenvolvimento do câncer, fatores ligados à imunidade, genética, hormônios, comportamento sexual, e entre outros, parecem influenciar os mecanismos, ainda incertos, que determinam a regressão ou a persistência da infecção pelo HPV, além da progressão para lesões precursoras e ao câncer. Normalmente, muitos anos transcorrem desde a infecção inicial até o aparecimento de lesões malignas invasivas. Durante este período as alterações celulares associadas ao processo de transformação maligna podem ser diagnosticadas através do exame citopatológico preventivo denominado Papanicolau.

Atualmente, existem duas vacinas disponíveis no mercado, a Vacina Quadrivalente (Gardasil) fabricada pelo laboratório Merck Sharp \& Dhome que protege contra quatro tipos do vírus 6,11, 16 e 18, e a Vacina Bivalente (Cervarix), fabricada pelo laboratório GSK que protege contra os vírus 16 e 18. No Brasil, foi aprovado para o ano de 2014 a inclusão da vacina quadrivalente pelo Sistema Único de Saúde (SUS) para meninas dos 11 aos 13 anos. Essas meninas serão imunizadas contra os vírus HPV6 e HPV11 (presentes em 90\% dos casos de verrugas genitais) e contra os HPV16 e HPV18 (de alto risco, presentes em 70\% dos casos de câncer do colo do útero). É importante enfatizar que as vacinas não protegem contra todos os tipos do HPV. Portanto, o exame preventivo deve ser feito mesmo em mulheres vacinadas. 


\subsection{Mecanismos de Reparo do dano ao DNA}

A molécula do DNA contém toda informação celular de um organismo e o mantimento de sua integridade é uma função de extrema importância para a garantia de sua sobrevivência. No entanto, o DNA é instável e sofre constantes ataques de fatores endógenos e exógenos à célula, tais como agentes químicos, físicos, produtos do metabolismo celular, erros na replicação e infecções (Lindahl, 1993)

Diferentes agentes podem causar diferentes tipos de danos que podem levar a alterações de base, de nucleotídeos, quebras de fita simples (single-strand breaksSSBs), quebras de fita dupla (double-strand breaks-DSBs), dano oxidativo e torções na molécula de DNA. Esses danos podem perturbar o estado de equilíbrio celular ativando ou inibindo certas vias bioquímicas que regulam o crescimento, a divisão celular e a replicação do DNA. O dano ao DNA é um evento relativamente comum na vida das células humanas, estima-se que cada célula sofra 10.000 lesões por dia. No entanto, quando o dano não é reparado eficientemente, as alterações sofridas na célula podem levar o indivíduo ao envelhecimento precoce, ao acúmulo de mutações que pode favorecer o desenvolvimento de doenças como o câncer e à morte (Lindahl, 1993; Sancar et al., 2004, Sulli et al., 2012).

As vias envolvidas com a resposta do dano ao DNA são vias de transdução de sinal que consistem em sensores, transdutores e efetores que visam o mantimento da integridade do genoma. Em geral, estas vias são ativadas por fosforilação de proteínas quinases como ataxia telangiectasia mutated (ATM) e ataxia telangiectasia and Rad3 related (ATR). Danos no DNA podem ativar ATM e/ou ATR, embora não seja conhecido exatamente como essas duas quinases reconhecem 0 dano. A quinase ATM responde principalmente a quebras da fita dupla do DNA induzidas por radiações ionizantes, ao passo que ATR responde a lesões induzidas pelos raios UV ou a agentes que causam bloqueio na forquilha de replicação. A cascata da transdução de sinais ativa as quinases CHEK1 and CHEK2. As vias de ATR-CHEK1 e ATM-CHEK2 não são vias paralelas de resposta aos danos danos na molécula de DNA, pois apresentam um elevado grau de interferência e conectividade. Assim, 
essas vias podem ativar as fosfatases Cdc25 e p53, inativando as quinases dependentes de ciclinas (CDK) e inibindo a progressão do ciclo celular através da ativação de checkpoints específicos. Consequentemente, os efetores do dano ao DNA podem ativar vias que levam à parada do ciclo celular, ao reparo do DNA, a resposta transcricional, e/ou a apoptose (Abraham, 2001; Lowndes, Murguia, 2000; Sancar et al., 2004; Sulli et al., 2012; Yang et al., 2003). Um esquema representativo dos processos envolvidos na resposta do dano ao DNA é apresentado na figura 2.

O reparo do dano ao DNA é dependente do tipo de lesão e do tipo celular em que foi gerado. Assim, esse processo pode envolver uma variedade de proteínas como nucleases, helicases, ligases, e polimerases de DNA. Os complexos protéicos efetores do reparo podem ativar diferentes vias de reparo como por excisão de bases (BER), excisão de nucleotídeos (NER), recombinação homóloga (HRR), junção de extremidades não homóloga (NHEJ) e/ou reparo por pareamento errôneo (MMR). Defeitos em qualquer uma destas vias podem levar a instabilidade genômica (Zhou, Elledge, 2000).

A instabilidade genômica, no entanto, não surge necessariamente como uma manifestação da transformação oncogênica, mas favorece a aquisição de alterações genéticas na célula, incluindo mutações em oncogenes e/ou genes supressores de tumor. Estas alterações podem conferir vantagens à célula permitindo seu crescimento, sobrevivência e, eventualmente, o estabelecimento de um tumor. Além disso, o fenótipo caracterizado pela instabilidade genômica pode permitir uma adaptação de clones celulares ao microambiente de um tumor emergente. Muitos vírus, em particular os vírus oncogênicos, expressam proteínas que perturbam os sistemas de reparo do dano ao DNA e as vias reguladoras do ciclo celular (Cahill et al.,1999; Sancar et al., 2004). 


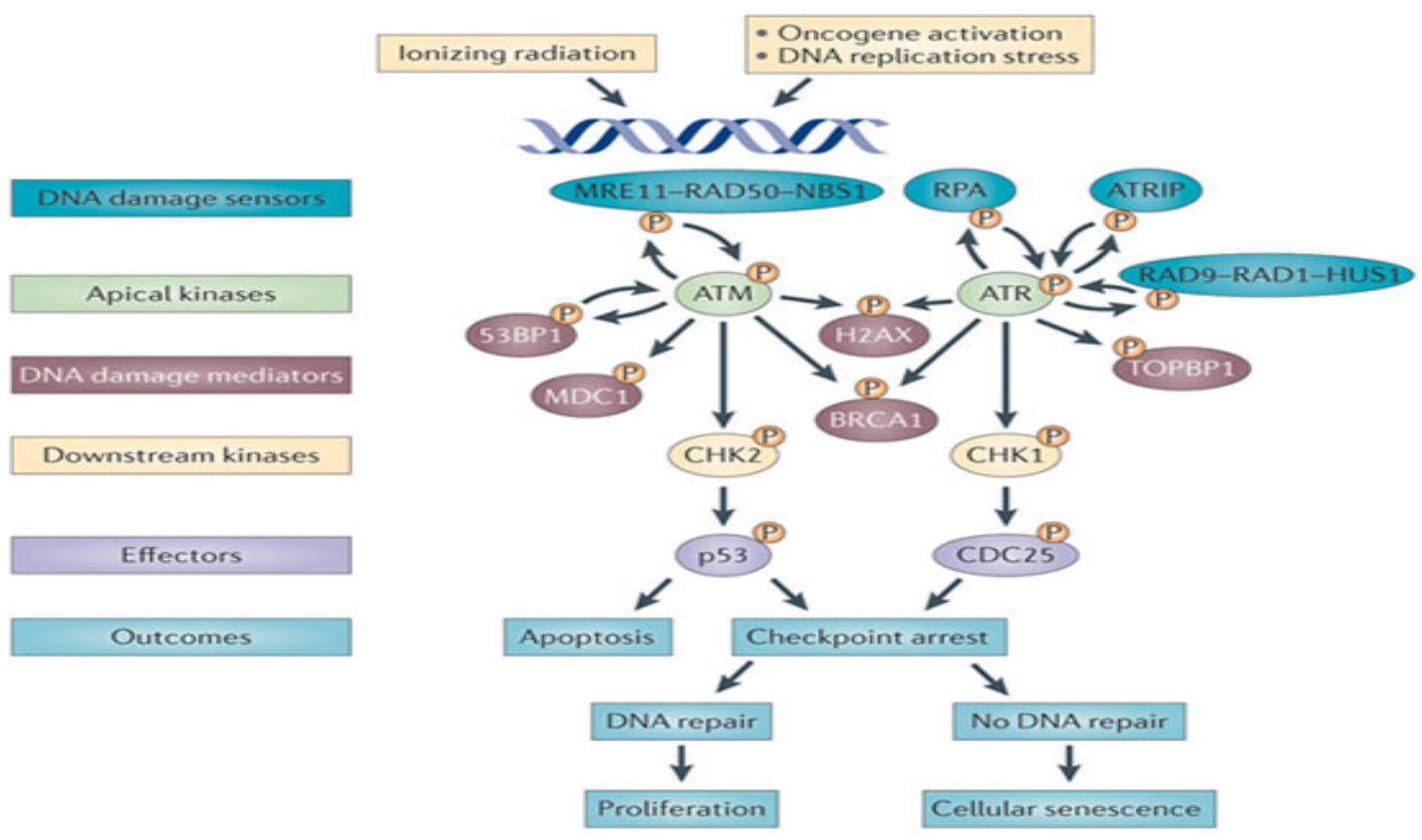

Nature Reviews | Cancer

Figura 2 - Representação esquemática de vias de sinalização ativadas em resposta ao dano ao DNA. As respostas celulares ao estresse genotóxico compreendem cascatas de sinalização nas quais as lesões no DNA atuam como um sinal inicial. Esse sinal é detectado por proteínas sensoras e transmitido aos efetores por transdutores de sinais. As proteínas efetoras recebem o sinal e executam diversas funções celulares, entre elas, bloqueio do ciclo celular, reparo do DNA e apoptose.

(Fonte: Sulli et al., 2012)

\subsection{As oncoproteínas E6 e E7 do HPV}

Através de microlesões no epitélio estratificado o HPV infecta células da camada basal, as células menos diferenciadas do tecido e as únicas que possuem atividade mitótica. A replicação do genoma do HPV depende da maquinaria de síntese de DNA da célula sendo regulada pelas proteínas virais E1 e E2. Após a infecção inicial, o DNA viral é mantido na forma de epissomo e em baixo número de cópias. A replicação ativa do DNA viral acontece nas células das camadas mais diferenciadas do epitélio como consequência da expressão de outras proteínas virias precoces. Finalmente, as proteínas estruturais são expressas nas camadas superiores onde novos vírus são formados e liberados por descamação da camada córnea (figura 1)(Doorbar, 2005; Howley, Lowy, 2007; Wilson et al., 2002). No caso de uma infecção persistente, o genoma antes mantido na forma epissomal pode se integrar no DNA da célula hospedeira. Esta integração usualmente interrompe a região dos genes E1-E2, resultando na perda do efeito repressor sobre a transcrição 
de E6 e E7 e no aumento dos níveis de expressão destas oncoproteínas, que são responsáveis em controlar a reentrada do ciclo celular (figura 3) (Munger, 2004).

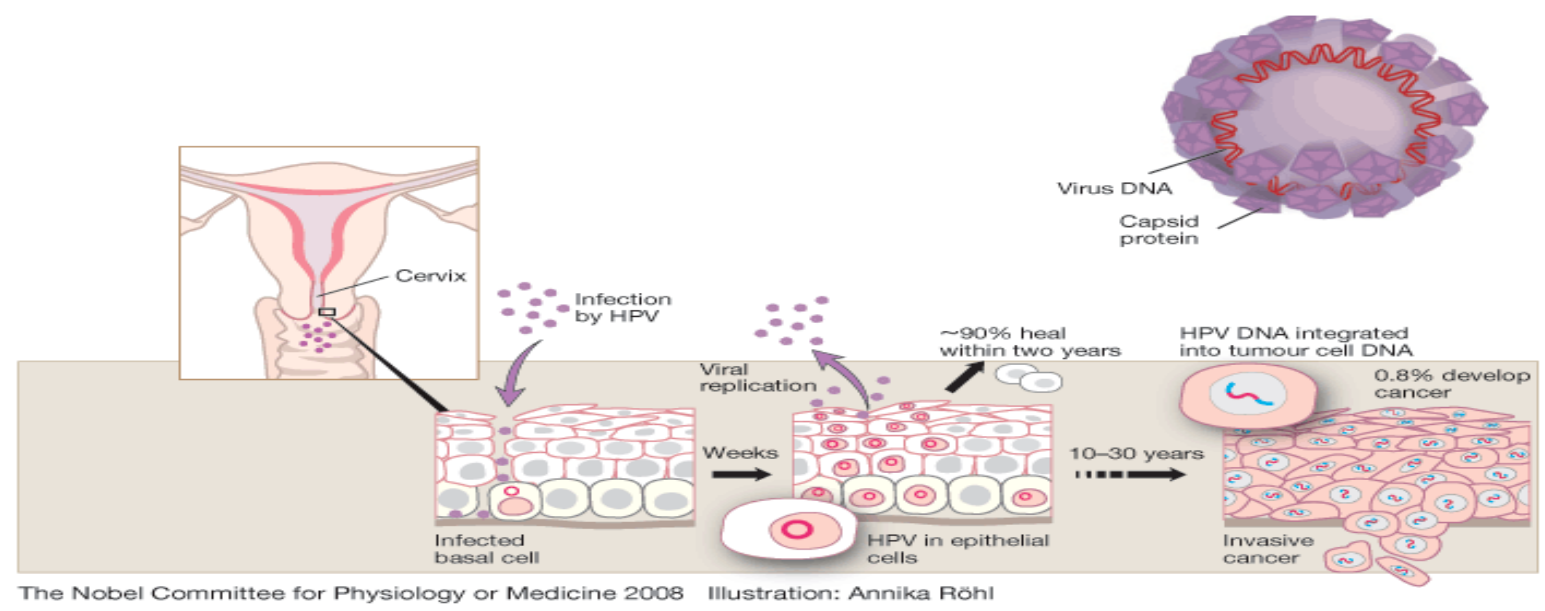

Figura 3 - O ciclo do HPV e a progressão do câncer do colo do útero: A infecção inicial do HPV nas células da camada basal através de miclolesões do epitélio e seu genoma mantido na forma de epissoma e em baixo número de cópias, onde o ciclo viral segue conforme a diferenciação do epitélio até a formação de novos vírus com a descamação da camada córnea. No caso de uma infecção persistente, o HPV pode se integrar no DNA na célula hospedeira próximo a regiões que regulam a transcrição de E1 e E2. Aumentando a expressão das proteínas virais E6 e E7, responsáveis em controlar o ciclo celular, resultano na proliferação celular descontrolada e consequentemente no desenvolvimento do câncer.

O HPV não codifica seu próprio conjunto de proteínas para sua replicação o que requer induzir à célula hospedeira a reentrar na fase $S$ do ciclo celular, e assim, passa utilizar sua maquinaria de replicação para duplicar seu DNA. Isso se dá através da ação das proteínas virais específicas sobre vários fatores celulares envolvidos na regulação do ciclo celular. No caso do HPV, as principais proteínas envolvidas nesse processo são as codificadas pelos genes E6 e E7. Os produtos destes genes são capazes de interagir com vários fatores celulares. Entre essas interações, destaca-se a capacidade da proteína E6 de unir-se à proteína supressora de tumor p53, alterar a sua capacidade funcional e promover sua degradação pela via de proteólise dependente de ubiquitina. A proteína E6 também pode ativar a expressão de subunidade catalítica da telomerase (hTERT) em células primárias, responsáveis por impedir a senescência celular (Crook et al.,1991; Kessis et al.,1993; Lechner et al.,1992; Scheffner et al.,1990). A proteína E7 é capaz de unir-se e inativar uma das principais proteínas supressoras de tumor a proteína do retinoblastoma $(\mathrm{pRb})$ e interromper a interação de $\mathrm{pRb}$ com o fator E2F (Barbosa et al.,1990; Dyson et al.,1989; Münger et al.,1989). Além disso, E7 induz a degradação 
de $\mathrm{pRb}$ pela via de proteólise dependente de ubiquitina e inibe inibidores de quinases dependentes de ciclinas p21 e p27 (Helt, Galloway, 2001). Acredita-se que estas interações desempenham um papel fundamental no processo de transformação celular induzida pelo HPV.

Os genes E6 e E7 são os únicos genes do HPV expressos em todos os tumores do colo do útero e nas linhagens celulares derivadas desses carcinomas e são responsáveis pela progressão do ciclo celular na célula hospedeira. Estas proteínas cooperam para imortalizar queratinócitos humanos in vitro (Halbert et al.,1992; Halbert et al.,1991; Liu et al.,1997; Münger et al.,1989; Watanabe et al.,1989; Zur Hausen, 1996). Além das interações descritas acima, foi observado que as proteínas E6 e E7 interagem com outros fatores celulares envolvidos na transdução de sinais, regulação de apoptose, regulação da transcrição e do ciclo celular (Howie et al., 2009; McLaughlin-Drubin, Münger, 2009). Assim, estas proteínas são capazes de prolongar o tempo de vida de queratinócitos humanos normais, alterar o ciclo celular e o programa de diferenciação destas células. Estes efeitos, por sua vez, promovem instabilidade genômica, contribuindo assim à transformação maligna (Akerman et al., 2001; Duensing et al., 2000; Francis et al., 2000; Nees et al., 2000; Sherman et al., 2002; Thomas, Laimins, 1998).

\subsection{O HPV e o reparo do dano ao DNA}

Em danos gerados no DNA, as células tendem a ativar a parada do ciclo celular para dar início a uma cascata de respostas. No entanto, células que expressam a oncoproteína E7 do HPV, a parada do ciclo celular é impedida, principalmente, través da sua interação com a proteína pRB e inibidores CDK, resultando na extensão do dano. Por outra via, muitos danos gerados no DNA resultaria com a morte da célula por apoptose, entretanto, células que expressam a oncoproteína E6, e principalmente através da sua degradação de p53, essa sinalização é impedida e a célula progride acumulando ainda mais erros. O bloqueio do ciclo celular e o impedimento da apoptose são vias extremamente importantes para reparar danos gerados ao DNA da célula, consequentemente, interferências 
nessas vias podem resultar em acúmulo de alterações genéticas (Cahill et al.,1999; Sancar et al., 2004; Tlsty et al., 1995)

Diferentes estudos mostram a relação das oncoproteínas virais do HPV com vias envolvidas no reparo do dano ao DNA. Por exemplo, foi observado que as proteínas E6 e E7 do HPV16 podem independentemente anular o checkpoint do fuso mitótico da célula, interromper a verificação pós-mitótica e a parada do crescimento mediada por p53 em resposta a danos no DNA (Demer et al., 1994; Duensing, Munger, 2002; Heilman et al., 2009; Kessis et al., 1993; Liu et al., 2007; Thomas, Laimins, 1998;]. Além disso, Song e colaboradores (1998) demonstraram que estas oncoproteínas podem modular a resposta ao danos no DNA, eles observaram que as células de camundongo, expressando as proteínas E6 e E7 de HPV de alto risco, quando danificadas por radiação ionizante, a síntese de DNA da célula era impedida gerando um acúmulo de erros em seu DNA.

Alterações nos sistemas de reparo do DNA associadas à presença de HPV têm sido descritas de maneira consistente em diferentes modelos experimentais. Por exemplo, deficiências no mecanismo de reparo por excisão de nucleotídeos (NER) têm sido observadas em queratinócitos orais imortalizados por HPV16 (Rey et al., 1999). Além disso, a expressão da proteína E6 de HPV16 tem sido associada à perda de indução da proteína p53R2, uma proteína envolvida na resposta ao dano ao DNA e ao estresse oxidativo mediada por p53 (Lembo et al., 2006). A expressão desta oncoproteína viral também foi associada a diversos eventos, como por exemplo, defeitos nos sistemas de reparo por excisão de nucleotídeos global e associado à transcrição (GNER e TCNER, respectivamente), diminuição no reparo de dímeros de timina induzidos por UV, redução nos níveis de reparo de quebras de dupla fita, e degradação da O6-metilguanina-DNA metiltransferase que elimina os grupos alquila das guaninas (Srivenugopal, Ali-Osman, 2002; Giampieri, Storey, 2004; Shin et al., 2006; , Therrien et al., 1999).

Finalmente, foi descrito que fibroblastos que expressam a proteína E7 de HPV16 são deficientes em GNER (Therrien et al., 1999) e que a expressão de E6 e E7 de HPV de alto risco induz quebras no DNA e aumentam a integração de DNA 
exógeno no genoma da célula hospedeira (Duensing, Münger, 2002; Kessis et al., 1993).

Por outro lado, o HPV pode também modular as respostas ao dano ao DNA recrutando proteínas de reparo para um local específico para tornar eficiente sua replicação. Gillespie e colaboradores (2012), observaram por imunofluorescência, que em células HPV positivas, as proteínas envolvidas nas vias de reparo dependente de ATM, incluindo $\mathrm{YH} 2 \mathrm{AX}, \mathrm{CHEK} 2$, BRCA1 e NBS1, são recrutados pelas proteínas E1 e E2 em focos nucleares específicos onde ocorrem a replicação viral e também de regiões no DNA da célula danificada pela radiação ionizante.

Estes estudos indicam que o HPV pode modular as vias de resposta ao dano ao DNA, utilizando as proteínas envolvidas no reparo para a sua replicação. Além disso, as proteínas virais impedem a parada do ciclo e impossibilita a indução da morte celular gerando e acumulando danos na célula. Essa alterações podem ser uma característica geral de células que expressam as oncoproteínas de HPV de alto risco e a resposta ineficiente do hospedeiro pode contribuir para o mantimento dessas lesões no DNA.

\subsection{HPV e instabilidade genômica}

A presença de alterações cromossômicas numéricas e estruturais são características típicas da maioria dos tumores sólidos e o carcinoma do colo do útero não é exceção. Estudos realizados para detectar alterações cromossômicas em câncer do colo do útero e em lesões precursoras mostraram que o ganho (por duplicação ou amplificação) e a perda (deleção) de regiões genômicas são eventos frequentes nas células afetadas. Ganhos nos cromossomos 1, 3q, 5p, 6p, 7, 8q, 9q, $16 q, 20$ assim como perdas em 2q, 3p, 4q, 6q, 11q, 13q, 16, 17 têm sido descritos e associados à presença de HPV (Alazawi et al., 2004; Arias-Pulido et al., 2002; Rao et al., 2004; Sokolova et al., 2007; Wilting et al., 2009; Wistuba et al.,1997). Em alguns casos estas alterações foram associadas ao aumento no número de cópias e atividade transcricional de genes localizados na área envolvida (Wilting et al., 2006). Alterações genômicas e amplificação gênica associada à presença de HPV foram 
também observadas em carcinomas orais, carcinomas escamosos laríngeos e em neoplasias intraepiteliais anais (Cattani et al., 1998; Gagne et al., 2005; Steenbergen et al., 1995).

Diversos estudos têm mostrado que tanto E6 como E7 de HPV de alto risco são capazes de induzir poliploidia em queratinócitos humanos mediante inibição do checkpoint pós-mitótico (Heilman et al., 2009; Liu et al., 2007; Southern et al., 2001). De fato, foi observado que E6 pode induzir poliploidia em queratinócitos por vias dependentes e independentes de p53 (Liu et al., 2007). Finalmente, foi observado que as proteínas E6 e E7 do HPV16 são capazes de induzir números anormais de centrossomos e fusos mitóticos com multiplos polos (Duensing et al., 2000) o que, certamente, favorece ao rápido acúmulo de alterações genéticas nas células infectadas pelo vírus. A poliploidização espontânea tem sido detectada em células da linhagem W12. Esta linhagem deriva de uma lesão do colo do útero de baixo grau, positiva para HPV16, diagnosticada histologicamente como neoplasia intraepitelial cervical 1 (NIC 1) (Pett et al., 2004; Stanley et al., 1989). Isto sugere que o aparecimento de células poliplóides é um evento precoce na história natural da infecção por HPV. Mais ainda, põe em evidência a existência de um fenótipo de instabilidade genômica que pode ter um papel importante no surgimento de células aneuplóides favorecendo a progressão da lesão (Boccardo, 2010). Esta hipótese é apoiada pela detecção de células altamente poliplóides e aneuplóides em lesões intraepiteliais de alto grau (Méhes et al., 2004).

Em conjunto, as observações descritas acima indicam que a presença do HPV de alto risco, principalmente, através da ação das oncoproteínas E6 e E7, promove a proliferação celular descontrolada, inativação dos checkpoints e inibição da apoptose, dessa maneira, as funções do sistema de reparo da célula podem ser alteradas. Assim, os defeitos no DNA são acumulados aumentando ou inibindo a atividade transcricional de genes importantes para a homeostase celular. Consequentemente, essa instabilidade genômica, acumula mutações e altera número de cromossomos e atividade transcricional de genes na célula em uma infecção persistente pelo vírus. Esses fatos podem contribuir aos processos do desenvolvimento neoplásico e ao estabelecimento e progressão tumoral. 
No entanto, o efeito da infecção por HPV e o impacto da expressão das oncoproteínas virais na expressão de genes associados aos mecanismos de reparo de dano ao DNA não têm sido explorados de maneira sistemática. Portanto, no presente estudo, avaliamos de maneira comparativa a expressão de 135 genes envolvidos nas vias de reparo de dano ao DNA em queratinócitos primários humanos (QPH) e em linhagens derivadas de carcinomas do colo do útero positivas (SiHa e HeLa) e negativas (C33A) para HPV. 


\section{OBJETIVO}

\subsection{Objetivo geral}

Estudar o efeito da infecção por HPV e o impacto das oncoproteínas virais na expressão de genes associados aos mecanismos de reparo de dano ao DNA.

\subsection{Objetivos específicos}

Caracterizar a expressão de genes associados às vias de reparo de dano ao DNA em linhagens celulares transformadas por HPV16 e HPV18 utilizando RTarrays específicos.

Estabelecer culturas em monocamadas e organotípicas de queratinócitos primários humanos que expressem as oncoproteínas E6 e E7 de HPV16 e 11.

Análise do efeito das oncoproteínas virais sobre expressão de genes de reparo do dano ao DNA em culturas organotípicas de queratinócitos humanos.

Validar os dados de expressão gênica mediante estudo dos níveis de proteína em células que expressam genes de HPV. 


\section{MATERIAL E MÉTODOS}

\subsection{Cultura de células em monocamada}

3.1.1 Linhagens celulres derivadas de tumores de colo do útero.

As linhagens celulares derivadas de cânceres do colo do útero SiHa (ATCC $\mathbb{B}$ HTB-35 ${ }^{\mathrm{TM}}$ ) positiva para HPV16; HeLa (ATCC ${ }^{8}$ CCL-2 ${ }^{\mathrm{TM}}$ ) positiva para HPV18 e C33A (ATCC $®$ CRM-HTB-31 ${ }^{\mathrm{TM}}$ ) HPV negativa, foram adquiridas da empresa ATCC e cultivadas em monocamada em meio MEM (Gibco® Minimum Essential Media, Life Technologies) suplementado com $10 \%$ de soro fetal bovino (SFB, Cultilab) (M10), em estufa úmida, a $37^{\circ} \mathrm{C}$, e com $5 \%$ de $\mathrm{CO}_{2}$.

\subsubsection{Queratinócitos e vetores retrovirais}

Queratinócitos primários humanos (QPH) de prepúcio de recém-nascidos obtidos comercialmente (\#cc-2507, Lonza, Basel, Switzerland) foram cultivados em meio KSFM (Life Technologies, Inc., Gaithersburg, MD) suplementado com fator de crescimento epidérmico $(5 \mathrm{ng} / \mathrm{mL})$ e extrato de pituitária bovina $(50 \mu \mathrm{g} / \mathrm{mL})$, em estufa úmida, a $37{ }^{\circ} \mathrm{C}$, e com $5 \%$ de $\mathrm{CO}_{2}$. Culturas de $\mathrm{QPH}$ foram transduzidas com vetores retrovirais contendo os genes E6 e E7 de HPV16 e 11. Os retrovírus contendo os genes do HPV16 foram gentilmente cedidos pela Dra. Denise A. Galloway (Fred Hutchinson Cancer Research Center, Seattle, USA) e estavam devidamente caracterizados (Demer, et al., 1994; Gewin, Galloway, 2001; Helt, Galloway, 2001). Os retrovírus que continham a sequência para o HPV 11 foram cedidos pelo Dr. Dennis J. McCance (University of Rochester, Rochester, New York, USA) e estão devidamente caracterizados (Guess, McCance, 2005).

Os plasmídeos recebidos, em papel filtro, foram crescidos em bactérias competentes DH5- $\alpha$ e inoculados em tubos de cultura contendo meio LB suplementados com o antibiótico de seleção. As bactérias foram incubadas a $37^{\circ} \mathrm{C}$ sob agitação por 24 horas e os plasmídeos forma purificados utilizando o PureYieldTM Plasmid Midiprep System (Promega, Madison, WI), conforme instruções do fabricante. 
Para a obtenção de queratinócitos que expressam os vetores retrovirais contendo os oncogenes E6 e E7 de HPV-16 e HPV11 os plasmídeos foram introduzidos em células da linhagem ecotrópica Bosc23 (ATCC® CCL-11270) por eletroporação. Em seguida, as células foram transferidas para placas de Petri de 100 $\mathrm{mm}$ com $7 \mathrm{~mL}$ de meio meio DMEM (Gibco, Life Technologies) com 10\% de Soro Fetal Bovino (D10) e incubadas a $37^{\circ} \mathrm{C}$ em atmosfera de $5 \%$ de $\mathrm{CO}_{2}$.

Após 48 horas, $5 \mathrm{~mL}$ do sobrenadante das células Bosc23 foi aspirado com uma seringa e acoplada a um filtro de 0,45 $\mu \mathrm{m}$ e gotejado na linhagem anfotrópica de fibroblastos de camundongo Am12 (Markowitz, 1988), mantidas em cultura em placas de Petri de $100 \mathrm{~mm}$ em uma confluência de 20\%. Em seguida foram adicionados $10 \mu \mathrm{L} / \mathrm{mL}$ de polibreno (Sigma-Aldrich, St. Louis, MO, EUA), que minimiza a repulsão eletrostática entre a membrana celular e o envelope viral. Após 8 horas foram adicionados $10 \mathrm{~mL}$ de D10 fresco. Após 48 horas o meio foi substituído por meio D10 com $500 \mu \mathrm{g} / \mathrm{mL}$ Geneticina (G418, GibcoBRL, MD, USA) ou 2,5 $\mu \mathrm{g} / \mathrm{mL}$ de Puromicina (Puromycin Dihydrochloride Gibco $\circledast$, Life Technologies), para os plasmídeos pLXSN e pBABE, respectivamente.

Após uma semana de seleção, momento em que todas as células controle estavam mortas, as células foram mantidas em meio D10 fresco até a formação de colônias. O sobrenadante destas células com os retrovírus capazes de tranduzir culturas de QPH com as sequências gênicas do HPV, foram gotejados nos queratinócitos conforme descrito acima. Após 45 minutos foram adicionados $5 \mathrm{~mL}$ de KSFM e após 4 horas o meio foi trocado por KSFM fresco. Finalmente os queratinócitos foram selecionados em meio KSFM com G418 (500 $\mu \mathrm{g} / \mathrm{mL})$ ou Puromicina $(2,5 \mu \mathrm{g} / \mathrm{mL})$ por 48 horas, ou até as culturas controle estarem mortas, e utlizados na obtenção de culturas em monocamadas e organotípicas. 


\subsection{Cultura organotípica de queratinócitos (raft)}

\subsubsection{Preparação do equivalente dérmico}

A linhagem de fibroblastos de camundongo J2 (derivada de NIH 3T3) (Chow, Broker, 1997) foi mantida em cultura utilizando meio D10 e quando atingiram 60$70 \%$ de confluência foram tripsinizadas. O número de células necessário foi determinado para obter uma concentração final de $1 \times 10^{5}$ células $/ 0,75 \mathrm{~mL}$ de equivalente dérmico (por exemplo para $7,5 \mathrm{~mL}$ de equivalente dérmico são necessárias $1 \times 10^{6}$ células $\mathrm{J} 2$ ). Logo após a centrifugação as células $\mathrm{J} 2$ foram ressuspendidas em um volume de SFB igual a 1/20 do volume total de equivalente dérmico a ser preparado (por exemplo, $500 \mu \mathrm{l}$ de SFB para $10 \mathrm{~mL}$ de equivalente dérmico).

Paralelamente, em um tubo estéril foram misturados um volume equivalente a 1/10 do volume final de equivalente dérmico a ser preparado de meio Ham's F12 10X (GibcoBRL), um volume igual de tampão de reconstituição 10X $\left(2,2 \% \mathrm{NaHCO}_{3}\right.$, $\mathrm{NaOH}$ 0,05 M, HEPES $200 \mathrm{mM}$ ) e um volume de colágeno tipo I de cauda de rato (BD Biosciences) correspondente a 8/10 do volume total de equivalente dérmico a ser preparado. Em seguida foram adicionadas as células J2 e a suspensão foi misturada por inversão evitando fazer bolhas e transferida para uma placa de 24 poços $(0,75 \mathrm{ml} /$ poço). Após a polimerização do colágeno a temperatura ambiente, por 40 minutos, adicionou-se $1 \mathrm{ml}$ de meio para raft [90\% meio 3+1 (3 DMEM + 1 HamF12), 10\% SFB; $1 \mathrm{nM}$ Toxina colérica (Sigma-Aldrich), $5 \mu \mathrm{g} / \mathrm{mL}$ Insulina (SigmaAldrich), $5 \mu \mathrm{g} / \mathrm{mL}$ apo-transferina (Sigma-Aldrich), 0,4 $\mu \mathrm{g} / \mathrm{mL}$ Hidrocortisona-21hemisuccinato (Sigma-Aldrich), 0,5 ng/mL EGF (Gibco/BRL)] a cada poço e a placa foi mantida a $37{ }^{\circ} \mathrm{C}$, em atmosfera de $5 \%$ de $\mathrm{CO}_{2}$ até a adição dos $\mathrm{QPH}$.

\subsubsection{Montagem da cultura organotípica}

Queratinócitos humanos primários (passagem 0-1) e os portadores dos genes E6 e E7 de HPV 16 e 11 foram cultivados com meio KSFM (Life Technologies) em placas de Petri de $60 \mathrm{~mm}$ até atingir uma confluência de $80-90 \%$. Em seguida, foram 
tripsinizados, contados, ressuspensos em KSFM $\left(2 \times 10^{5}\right.$ células por $\left.\mathrm{mL}\right)$ e colocados sobre o equivalente dérmico em uma densidade de $1 \times 10^{5}$ células/poço em uma placa de 24 poços. Logo após foi adicionado $0,5 \mathrm{~mL}$ de meio para raft a cada poço e a placa foi colocada a $37{ }^{\circ} \mathrm{C}$ e $5 \% \mathrm{CO}_{2}$. No dia seguinte, o meio foi substituído por 1 $\mathrm{mL}$ de meio para raft fresco e a matriz de colágeno de cada poço foi descolada da placa utilizando-se uma espátula. Após 3 a 8 horas cada matriz de colágeno, com a superfície coberta por queratinócitos, foi transferida para uma grelha de aço colocada em uma placa de Petri de $60 \mathrm{~mm}$. Posteriormente, foram adicionados $5 \mathrm{~mL}$ de meio para raft por placa e as mesmas foram mantidas a $37^{\circ} \mathrm{C}$ em atmosfera de $5 \%$ de $\mathrm{CO}_{2}$. Finalmente, após 9-11 dias na interface meio-ar os rafts foram utilizados para a obtenção de RNA.

\subsection{Silênciamento gênico.}

\subsubsection{Produção de lentivírus}

Para o silênciamento dos genes TREX1 e RPA1 foram utilizados de vetores lentivirais que codificam shRNA para os específicos genes clonados em plasmídeos pLKO.1 puro. Estes vetores derivam de uma biblioteca, comercial para silênciamento, de genes envolvidos nas vias de reparo de dano ao DNA (MISSION® shRNA Human Gene Family Sets, DNA Repair Pathway, SH1811, Sigma-Aldrich,St. Louis, MO, USA). Uma alíquota de cada clone bacteriano foi transferida para $8 \mathrm{~mL}$ de meio LB suplementado com ampicilina $(75 \mu \mathrm{g} / \mathrm{mL})$ e os plasmídeos purificados utilizando o PureYieldTM Plasmid Midiprep System segundo instruções do fabricante (Promega). Posteriormente, os plasmídeos foram quantificados no espectrofotômetro (NanoDrop 2000, Thermo Scientific, USA) e analisados em gel de agarose 1\%.

Para a produção de partículas lentivirais $10^{6}$ células da linhagem HEK293T

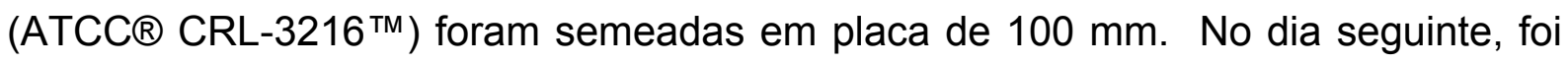
preparado um mix contendo $2,6 \mu \mathrm{g}$ do plasmídeo de interesse, $16 \mu \mathrm{l}$ de FUGENE (Promega), $182 \mu \mathrm{l}$ de DMEM e $26 \mu$ do MISSION® Lentiviral Packaging Mix (SHP001, Sigma-Aldrich) incubado por 15 minutos a temperatura ambiente. Posteriormente, o mix foi gotejado sobre a placa contendo a linhagem HEK293T e 
seguiu-se acrescentando $7 \mathrm{~mL}$ de meio D10. Após 2 e 3 dias coletou-se o meio das placas contendo os lentivírus, que foram mantidos no freezer $-70{ }^{\circ} \mathrm{C}$ até a sua utilização para transdução.

\subsubsection{Silênciamento de genes específicos nas Linhagens Transformadas por HPV}

Para a transdução das linhagens celulares SiHa (HPV16) e HeLa (HPV18) foram plaqueados a $1 \times 10^{5}$ células/poço de placa de 6 poços. Os sobrenadantes contendo os lentivírus foram filtrados com filtros de poro $0,45 \mu \mathrm{m}$ e gotejados sobe as células já com o meio de cultura aspirados e posteriormente acrescido de 10 $\mu \mathrm{L} / \mathrm{mL}$ Polibreno (Sigma-Aldrich). Após 8 horas o meio foi substituido por meio de cultura M10 fresco. Passadas 48 horas da transdução foi iniciada a seleção das células com 2,5 $\mu \mathrm{g} / \mathrm{mL}$ de puromicina, as células foram mantidas na estufa a $37^{\circ} \mathrm{C}$ com $5 \%$ de $\mathrm{CO}_{2}$ até as células controle estarem mortas. Em seguida, as células foram utilizadas para os ensaios de viabilidade celular.

\subsection{Ensaio de Viabilidade Celular}

As células SiHa e HeLa infectadas com vetores lentivirais foram cultivadas em placa de Petri de $100 \mathrm{~mm}$ até atingirem uma confluência de 80-90\%. Em seguida, foram tripsinizadas, contadas e semeadas em placas de cultura de 96 poços $\left(1 \times 10^{4}\right.$ células por poço).

A viabilidade celular foi avaliada pela utilização de resazurina (Alamar Blue, Invitrogen, Carlsbad, CA, USA), a qual é uma substância de cor azul, que é reduzida na presença de células viáveis à resofurina, substância de coloração vermelha. Após 48 hora do plaqueamento das linhagens silênciadas, cada poço foi acrescido de 10 $\mu \mathrm{L}$ de Alamar Blue e a placa incubada a $37^{\circ} \mathrm{C}$ em atmosfera de $5 \%$ de $\mathrm{CO}_{2}$ por um período de até 5,5 horas. A leitura da absorbância foi realizada em espectofotômetro nos comprimentos de onda de $600 \mathrm{~nm}$ (cor vermelha) e $560 \mathrm{~nm}$ (cor azul) e a viabilidade foi calculada pela redução das células controle em relação as células silênciadas utilizando a fórmula do fabricante. A diferença estatística foi determinada para a medição realizada no tempo de 4 horas (teste t Student $p<0,05$ ). 


\subsection{Análise da expressão de genes envolvidos nas vias de reparo de dano ao DNA}

\subsubsection{Extração e quantificação do RNA}

O RNA total das diferentes culturas foi isolado utilizando TRIzol ${ }^{\circledR}$ (Invitrogen, Carlsbad, CA, USA) conforme as instruções do fabricante. A quantidade do RNA foi medida utilizando-se o NanoDrop ${ }^{\circledR} 2000$, onde a absorbância óptica foi obtida para cada amostra. A concentração de RNA $(\mu \mathrm{g} / \mu \mathrm{l})$ foi calculada utilizando a fórmula $(\mathrm{OD} 260 \times 40 \mu \mathrm{g}) / 4$. As amostras foram diluídas em água livre de RNase e mantidas em freezer $-70^{\circ} \mathrm{C}$ até sua utilização.

\subsubsection{Análise da integridade do RNA}

Os RNA extraídos, conforme descrito anteriormente, foram analisados em gel de agarose 1\% em TAE (40mM Tris-Acetato, 1 mM EDTA) preparado com GelRed ${ }^{\text {TM }}$ Nucleic Acid Gel Stain, 10,000X in Water (Biotium). Para cada amostra foram utilizados $1 \mu \mathrm{l}$ de RNA, $4 \mu \mathrm{l}$ de água e $5 \mu \mathrm{l}$ de tampão de amostra (TAE 2X, glicerol $30 \%$ e $7 \mathrm{M}$ uréia). As amostras foram incubadas em banho-Maria a $65{ }^{\circ} \mathrm{C}$ durante 10 minutos sendo imediatamente transferidas ao gelo (5 minutos), e centrifugadas rapidamente. Finalmente, as amostras foram aplicadas no gel e submetidas a eletroforese a 70 volts em tampão de corrida (TAE 1X) durante 30-40 minutos. As imagens foram adquiridas no sistema de captura de imagem MultiDoc-It ${ }^{\mathrm{TM}}$ utilizando o software fornecido pelo aparelho.

\subsubsection{Controle da contaminação por DNA genômico}

Para controle da contaminação por DNA genômico as amostras de RNA (2 $\mu \mathrm{g})$, foram tratadas com RQT RNase-Free DNase (Promega), conforme as condições do fabricante. A eficiência do trantamento foi comprovada através de uma PCR convencional utilizando um par de primers que amplifica uma região intrônicas do gene hMLH-1 (F:TGGTGTCTCTAGTTCTGG; R:CATTGTTGTAGTAGCTCTGC) seguindo o protocolo do fabricante (GoTaq ${ }^{\circledR}$ Flexi DNA Polymerase- Promega) . 
Para analizar o resultado do amplificado, as amostras foram aplicadas em um em um gel de agarose $2 \%$ corado com GelRed, submetido a eletroforese, e visualizado sob luz ultravioleta.

\subsubsection{Síntese e controle do cDNA}

A síntese de cDNA para a utilização nos arrays comerciais foi realizada utilizando o $R T^{2}$ First Strand Kit (SABiosciences; Frederick, MD, USA) de acordo com as instruções do fabricante. Para cada amostra, $2 \mu \mathrm{g}$ de RNA foram adicionados a $2 \mu \mathrm{l}$ de tampão eliminação de gDNA 5x e água livre de RNase para um volume final de $10 \mu \mathrm{l}$. A mistura foi mantida a $42{ }^{\circ} \mathrm{C}$ por $5 \mathrm{~min}$, seguido por resfriamento em gelo por, pelo menos, 2 min. O coquetel para RT-PCR foi preparado com $4 \mu \mathrm{l}$ de tampão RT3, $1 \mu \mathrm{l}$ de primer, $2 \mu \mathrm{l}$ de mix de enzima para RT3 e água livre RNase até completar $10 \mu \mathrm{l}$. O coquetel foi adicionado à mistura inicial e incubado a $42{ }^{\circ} \mathrm{C}$ por $15 \mathrm{~min}$ e $95^{\circ} \mathrm{C}$ por $5 \mathrm{~min}$. O produto da reação de RT-PCR foi diluído em $91 \mu \mathrm{l}$ água livre de RNase e mantido a $-70{ }^{\circ} \mathrm{C}$.

O resultado da síntese de cDNA foi testado, quanto a sua eficiência, através de uma PCR convencional com um par de primers que reconhecem sequências localizadas em éxons diferentes do gene Notch2.1 (amplificam de maneira específica DNA resultantes da reação da transcriptase reversa)(F: CCAACCAGTTCTCCTGC; R: GTGGTTAGGGCAGTCATC). As amostras foram aplicadas em um em um gel de agarose $2 \%$ corado com GelRed, submetido a eletroforese, e visualizado sob luz ultravioleta.

\subsubsection{Análise da expressão gênica utilizando arrays comerciais}

Os $2 \mu \mathrm{g}$ de cDNA resultantes da RT-PCR foram preparados para as reações de PCR em tempo real (qPCR). O mix para as reações de qPCR dos arrays comerciais foi preparado com $1.275 \mu \mathrm{l}$ de SYBR green PCR Master Mix (Applied Biosystems, Foster City, CA, USA), $102 \mu \mathrm{l}$ de cDNA diluído e $1173 \mu \mathrm{l}$ de água livre de RNase. A solução foi distribuída colocando $25 \mu \mathrm{l}$ em cada um dos 96 poços da placa de PCR array que já continha os iniciadores de interesse. Além dos 84 genes analisados 
para cada via em estudo, as placas de PCR array continham 5 controles endógenos constitutivos diferentes, 1 controle de contaminação por DNA genômico, 3 controles da transcriptase reversa e 3 controles positivos para PCR.

As reações de qPCR foram realizadas em um aparelho 7500 Real-Time PCR System (Applied Biosystems, Foster City, CA, USA) segundo as instruções do fabricante. Brevemente, as condições de ciclagem foram: $95{ }^{\circ} \mathrm{C}$ por 10 min e 40 ciclos com temperatura de $95^{\circ} \mathrm{C}$ por $15 \mathrm{~s} \mathrm{e} 60{ }^{\circ} \mathrm{C}$ por 1 minuto, seguido pelo período de dissociação.

Os níveis de mRNA dos genes envolvidos na sinalização de dano do DNA no reparo de dano ao DNA foram determinados na plataforma Superarray (Frederick, MD, USA) $R T^{2}$ Profiler ${ }^{\mathrm{TM}}$ PCR Array PAHS-029A (DNA Damage Signaling Pathway) e PAHS-042A (The Human DNA Repair), seguindo as indicações do fabricante.

As análises dos resultados qPCR foram realizadas através do método $2^{-\triangle \Delta C t}$, sendo que, como controle foi utilizado a média dos valores de Ct obtidos para os cinco genes constitutivos da placa de PCR array (B2M, HPRT1, RPL13A, GAPDH e ACTB). Para analisar os resultados do PCR array utilizou-se o Software $R T^{2}$ Profiler PCR Array Data Analysis Template v3.2 disponível no site da empresa: http://pcrdataanalysis.sabiosciences.com/pcr/arrayanalysis.php.

A quantificação foi baseada na observação da abundância dos produtos no ciclo de PCR onde as reações estão em fase exponencial de amplificação. $O$ acúmulo dos produtos de PCR nessa fase foi detectado em tempo real, através da ligação do SYBR® Green, que é uma molécula cuja emissão de fluorescência aumenta várias vezes quando ligada ao DNA dupla-fita. Através da definição arbitrária da região exponencial de amplificação, foram determinados os CTs (threshold cycle) de cada transcrito. A quantificação relativa ou método comparativo se baseia na diferença $(\triangle C T)$ entre o CT do gene alvo e o CT do gene de referência, sendo ambos os valores previamente normalizados pelo Ct de um gene constitutivo (um gene de expressão constitutiva, que normalmente não apresenta variação de expressão entre as amostras estudadas) (Pfaffl et al., 2002). 
Para tanto se utiliza a seguinte relação:

$\Delta \Delta \mathrm{Ct}=[\Delta] \mathrm{Ct}$, amostra $-[\Delta] \mathrm{Ct}$, controle

$[\Delta] \mathrm{Ct}=\mathrm{Ct}$, amostra $-\mathrm{Ct}$, housekeeping

Nível de expressão do gene alvo $=2^{-\Delta \Delta C t}$

Todos os experimentos foram realizados em triplicata e os resultados são indicados em média e desvio padrão. Para variáveis quantitativas utilizou-se o teste $\mathrm{t}$ de Student que avaliou a significância estatística da diferença entre os valores de expressão gênica, assumindo uma distribuição bicaudal e um modelo de variância heterocedástico. Foram considerados estatisticamente significantes os valores de $p$ $<0,05$. Além disso, os genes foram considerados diferencialmente expressos quando apresentaram uma diferença de expressão de pelo menos 2 vezes (maior ou menor) quando comparados aos mesmo genes do grupo controle.

\subsubsection{Validação dos dados de expressão gênica por qPCR.}

\subsubsection{Desenho dos primers}

Os primers correspondentes aos genes de interesse selecionados no estudo foram desenhados para análise por qPCR. Primeiramente, os primers foram analisados in silico com auxílio das ferramentas disponíveis em http://primerdepot.nci.nih.gov/ que gerou primers com aproximadamente 20 nucleotídeos, com capacidade para gerar fragmentos entre 50 e 160 pb, além de apresentarem uma temperatura de anelamento entre 58 e $64{ }^{\circ} \mathrm{C}$. Posteriormente, seguimos para analisar a capacidade dos primers de formar dímeros ou estruturas secundárias em http://www.idtdna.com/site. Continuamos as análises pareando e verificando a capacidade dos primers em anelar ao genoma Humano, evitando assim, uma amplificação inespecífica com o DNA caso houvesse ainda algum resquício de contaminação. Estas análises foram realizadas utilizando http://blast.ncbi.nlm.nih.gov/Blast.cgi. Os primers utilizados e o tamanho esperado dos amplificados gerados estão listados na tabela 1. 
Tabela 2 - Sequência dos oligonucleotídeos utilizados para quantificação do mRNA dos genes selecionados.

\begin{tabular}{|l|l|c|c|}
\hline \multicolumn{1}{|c|}{ Gene } & \multicolumn{1}{|c|}{ Sequência (5'->3') } & Amplificado & Tm \\
\hline TREX1 & F:GGTCCCACTAAGGAAACCACC & $113 \mathrm{bp}$ & 60,27 \\
\hline NM_016381.4 & R:GGGCAGAAGCACATCTCAGGC & & 63,64 \\
\hline & & & \\
\hline RAD51 & F:GGTGAAGGAAAGGCCATGTA & $147 \mathrm{bp}$ & 57,49 \\
\hline NM_002875 & R:GGTCTGGTGGTCTGTGTTGA & & 59,53 \\
\hline RAD54L & & & \\
\hline NM_003579.3 & R:AGAGCCCAGAGGACCTTGAT & & 55,09 \\
\hline & & & 59,96 \\
\hline RPA1 & F:GCTGAAGCAGTTGGAGTGAA & $150 \mathrm{bp}$ & 58,40 \\
\hline NM_002945.3 & R:AGTAGAACCCATTCCCGAGC & & 59,17 \\
\hline & & & \\
\hline RPL0 & F:CCTCATATCCGGGGGAATGTG & $95 \mathrm{pb}$ & 60,0 \\
\hline NM_001002 & R:GCAGCAGCTGGCACCTTATTG & & 62,48 \\
\hline & & & \\
\hline
\end{tabular}

\subsubsection{Análise da expressão gênica por qPCR}

As reações de PCR em tempo real foram realizadas utilizando $50 \mathrm{ng}$ de cDNA das linhagens celulares, previamente tratadas com DNase I, 6,5 $\mu \mathrm{L}$ do corante SYBR Green Dye (Life Tecnólogies) e a quantidade apropriada de primers, dependendo do gene de interesse, resultando em uma reação com um volume final de $12 \mu \mathrm{l}$. Para cada gene foi padronizadao a melhor concentração de primers, que variou entre 20 e $100 \mathrm{nM}$, e da temperatura de anelamento, que variou entre 60 e 64 ${ }^{\circ} \mathrm{C}$. As reações foram realizadas em triplicata em um termociclador 7500 Real-Time PCR System (Life Tecnologies) e as condições de ciclagem foram: $95^{\circ} \mathrm{C}$ por $10 \mathrm{~min}$ e 40 ciclos com temperatura de $95^{\circ} \mathrm{C}$ por $15 \mathrm{~s}$ e $60{ }^{\circ} \mathrm{C}$ por 1 minuto, seguido pelo período de dissociação.

Os resultados de qPCR para os genes de interesse selecionados foram analisados através do método comparativo $2^{-\Delta \Delta \mathrm{Ct}}$ utilizando o gene RPLO como gene constitutivo com ajuda do software 7500 Software v2.0.6. Todos os experimentos foram realizados em triplicata e os resultados são indicados em média e desvio padrão. 


\subsection{Análise da expressão de proteínas envolvidas nas vias de reparo de dano ao DNA}

\subsubsection{Extração de proteínas}

A extração de proteínas das linhagens analisadas foi realizada mediante lise celular e posterior separação da fração protéica. Para isto, 500-700 $\mu \mathrm{l}$ de solução de lise (150 mM NaCl, 50 mM Tris- $\mathrm{HCl}$ pH 7,5, 0,5\% NP40, 0,1 mM EDTA) e inibidores de proteases 20X (Complete Mini, Roche) foram adicionados a cada placa de células que foram coletadas mediante o uso de um cell scraper e transferidas a um tubo Eppendorf de 1,5 mL. Em seguida, as células foram incubadas no gelo durante 15 minutos e centrifugadas $14000 \mathrm{rpm}$ à $4{ }^{\circ} \mathrm{C}$, durante 20 minutos. Finalmente, $\mathrm{O}$ sobrenadante foi transferido para um novo tubo e as amostras estocadas a $-70{ }^{\circ} \mathrm{C}$. A concentração protéica foi determinada pelo método de Bradford.

\subsubsection{Western blot}

As amostras de proteínas foram submetidas a eletroforese em gel de SDSpoliacrilamida $10 \%$ ou $12 \%$ utilizando o sistema mini-Protean II Cell (Bio-Rad). Para o preparo de $5 \mathrm{~mL}$ do gel de separação de $10 \%$ de acrilamida foram utilizados: 1,97 $\mathrm{mL}$ de $\mathrm{H}_{2} \mathrm{O}$ Milli-Q, 1,25 mL de lower buffer (Tris-HCl 1,5 M pH 8,8, SDS 0,4\%), 1,65 $\mathrm{mL}$ de acrilamida-bisacrilamida (29:1) 30\%, $100 \mu \mathrm{L}$ de persulfato de amônio 10\% (APS) e 1,5 $\mu \mathrm{L}$ de TEMED (Sigma-Aldrich). Na porção superior do gel de separação foi aplicado um gel de stacking 4\% composto por: 3,6 mL de $\mathrm{H}_{2} \mathrm{O}$ Milli-Q, $625 \mu \mathrm{L}$ de upper buffer (Tris-HCl 1,0 M pH 6,8, SDS 0,4\%), $665 \mu$ de acrilamida-bisacrilamida (29:1) $30 \%, 100 \mu \mathrm{L}$ de APS $10 \%$ e $1,5 \mu \mathrm{L}$ de TEMED para um volume final de $5 \mathrm{~mL}$.

As amostras foram preparadas colocando-se $30 \mu \mathrm{g}$ de proteína em tampão de amostra v/v (Tris-HCl 240 mM pH 6,8, SDS 0,8\%, $\beta$-mercaptoetanol 200 mM, glicerol $40 \%$ e azul de bromofenol 0,02\%), desnaturadas a $95{ }^{\circ} \mathrm{C}$ durante 10 minutos e mantidas no gelo por 5 minutos. Em seguida, as amostras foram aplicadas no gel e submetidas a eletroforese a 80-120 V em tampão de corrida (glicina $192 \mathrm{mM}$, Tris $25 \mathrm{mM}$, SDS 0,1\%). Finalmente as amostras foram eletrotransferidas (Mini Trans-Blot 
Cell, BIO-RAD) para uma membrana de polivinilidene difluoreto (PVDF) (Hybond-P, Amersham Pharmacia Biotech) a $250 \mathrm{~mA}$ em tampão de transferência (glicina 200 $\mathrm{mM}$, Tris $25 \mathrm{mM}$, metanol $20 \% \mathrm{v} / \mathrm{v}$ (Merck)) durante $1 \mathrm{~h}$ a $4{ }^{\circ} \mathrm{C}$. A transferência foi conferida através da coloração com Ponceau (SIGMA) 0,1\% em ácido acético 1\%.

As membranas foram analisadas utilizando anticorpos específicos para as proteínas: CHK2 ( \#3440, Cell Signaling), DNA Ligase I (ab615, Abcam), FEN1 (ab17993, Abcam), MEK6 (ab52937, Abcam), MRE11 [H-300] (sc-22767, Santa Cruz Biotechnology), OGG1 [HRP] (ab81624, Abcam), PCNA (13-3900, Zymed), PNK (ab151418, Abcam), Rad51 [H-92] (sc-8349, Santa Cruz Biotechnology), Rad9 (ab70810, Abcam), RPA70 [EPR3472] (ab79398, Abcam), SMC1 (ab21583, Abcam) e TREX1 (ab83890, Abcam); e os anticorpos para as proteína de expressão constitutiva: tubulina (sc-25259, Santa Cruz Biotechnology) e actina (sc-1615, Santa Cruz Biotechnology). Inicialmente, as membranas foram bloqueadas com PBS-T $\left(137 \mathrm{mM} \mathrm{NaCl}, 2,7 \mathrm{mM} \mathrm{KCl}, 10 \mathrm{mM} \mathrm{Na} \mathrm{HPO}_{4}, 2 \mathrm{mM} \mathrm{KH}_{2} \mathrm{PO}_{4}, \mathrm{pH} 7,4\right.$, Tween-20 $0,05 \%$ ) cotendo $5 \%$ de leite em pó durante 1 hora. Em seguida, as membranas foram enxaguadas rapidamente em PBS-T e incubadas overnight na presença de um dos anticorpos específicos descritos acima. Os anticorpos foram diluídos em PBS-T com $1 \%$ de leite nas concentrações sugeridas pelo fabricante. Posteriormente, as membranas foram lavadas (4x) com PBS-T durante 5 minutos e incubadas durante 1 hora na presença de anticorpos secundários anti-lgG de camundongo produzido em cabra (205-032-176, jackson) ou anti-coelho (NIF824, Amersham) na diluição de 1:5000 em PBS-T contendo 1\% leite. Finalmente, as membranas foram lavadas durante 5 minutos $(4 \mathrm{x})$ com PBS-T e reveladas utilizando o kit ECL (Amersham) 


\section{RESULTADOS}

\subsection{Análise da expressão de genes das vias de reparo de dano ao DNA em}

células normais e linhagens derivadas de tumores do colo do útero

No presente estudo, a expressão de 135 genes envolvidos nas vias de reparo de dano ao DNA, contidos em 2 arrays comerciais, foi analisada por qPCR. Para isto, o RNA total foi purificado a partir de culturas das linhagens celulares C33A, SiHa e HeLa. Como controle foi utilizado RNA total obtido a partir de culturas de QPH. Para cada linhagem foram realizadas pelo menos quatro extrações independentes para cada array conforme exemplificado na figura 4.
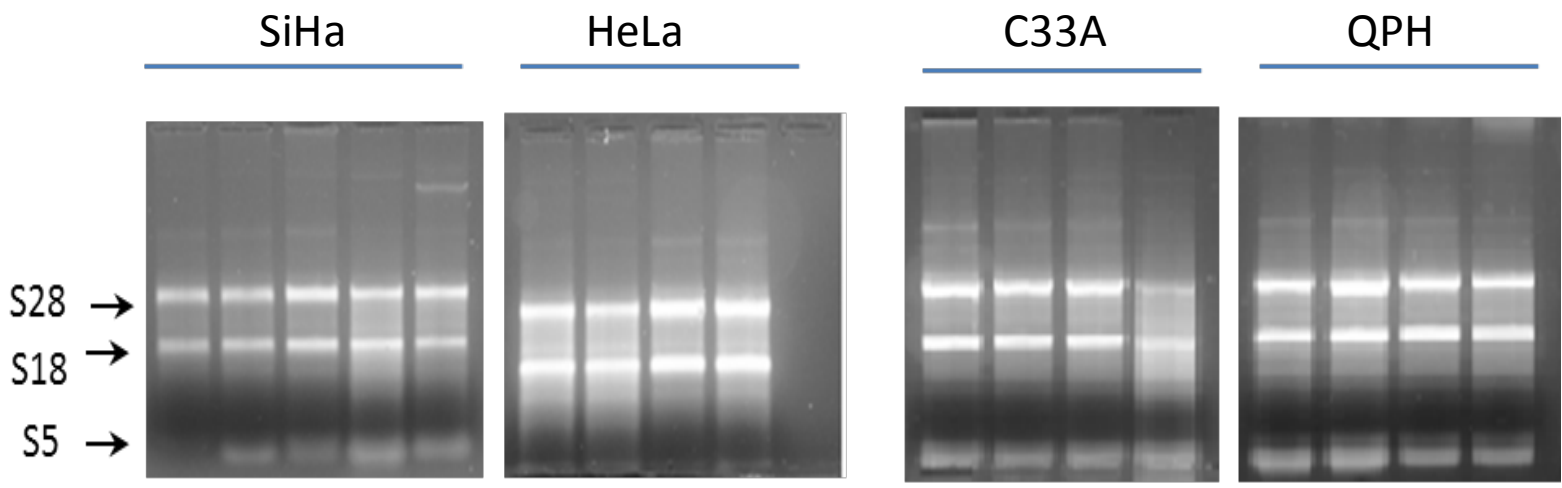

Figura 4 - Análise da integridade do RNA. Análise da integridade de amostras de RNA total de queratinócitos normais e linhagens derivadas de câncer de colo do útero. O RNA total foi extraído a partir de culturas de QPH, SiHa, HeLa e C33A pelo método de Trizol segundo as instruções do fabricante. Um micrograma de RNA foi aplicado em gel de agarose 1\% corado com GelRed, submetido a eletroforese, e visualizado sob luz ultravioleta. As setas indicam as bandas correspondentes aos RNA ribossômicos 28S, $18 \mathrm{~S}$ e $5 \mathrm{~S}$.

As três amostras de RNA de cada linhagem celular que, por critérios visuais e espectrofotométricos, apresentaram melhor qualidade foram escolhidas e preparadas para a reação de RT-PCR. Os cDNAs obtidos foram utilizados na análise do padrão de expressão de 84 genes envolvidos nas vias de sinalização de dano ao DNA e 84 genes envolvidos nas vias de reparo de dano ao DNA. Uma vez, que estas vias estão correlacionadas, vários destes genes encontram-se repetidos nos dois arrays, totalizando 135 genes diferentes. Os genes repetidos nos dois arrays foram utilizados como controle de reprodutibilidade dos resultados obtidos. 
Em primeiro lugar analisamos a diferença de expressão gênica entre queratinócitos primários (considerado arbitrariamente como grupo referência), com cada uma das linhagens tumorais [SiHa (HPV16), HeLa (HPV18) e C33A (HPV negativa)]. Os resultados obtidos mostram que dos 84 genes, presentes no array, envolvidos nas vias de sinalização de dano ao DNA, apenas 21 não apresentaram diferença de expressão entre as linhagens de tumor do colo do útero e os queratinócitos normais. Dos 63 genes restantes, 52 genes apresentaram expressão diferencial entre C33A e QPH, ao tempo que nas linhagens HPV positivas 53 genes foram diferencialmente expressos entre QPH e SiHa, e 15 entre QPH e HeLa.

Da mesma maneira, analisando os 84 genes envolvidos nas vias de reparo de dano ao DNA, apenas 13 genes não apresentaram diferença na sua expressão quando comparados com os queratinócitos normais. Dos 71 genes restantes, 52 genes apresentaram expressão diferencial entre C33A e QPH, 36 genes foram diferencialmente expressos entre QPH e SiHa, e 19 entre QPH e HeLa. Estes resultados estão resumidos na figura 5 .

A) Vias de sinalização de dano ao DNA

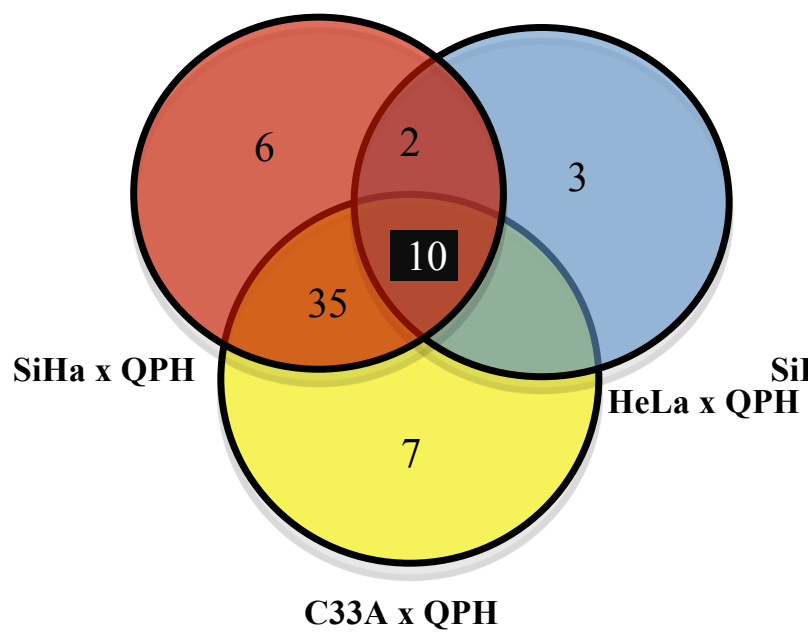

B) Vias de reparo de dano ao DNA

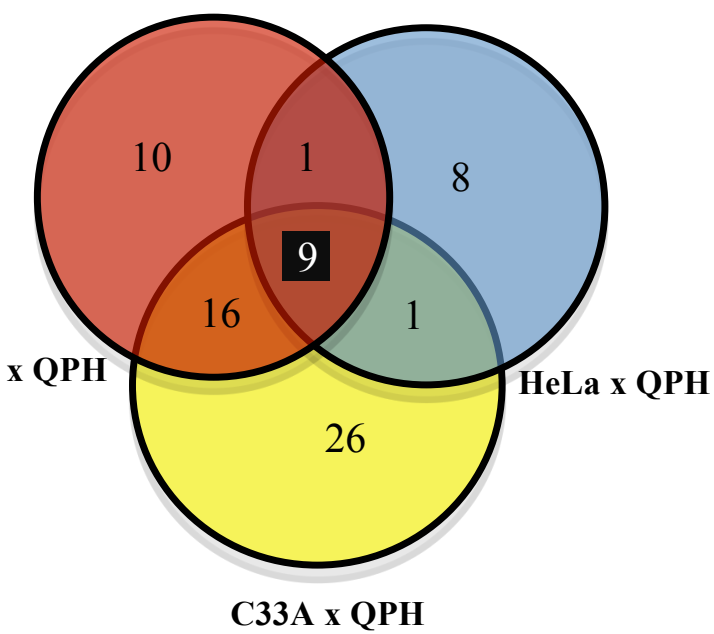

Figura 5 - Comparação da expressão de genes envolvidos nas vias de sinalização de dano ao DNA e nas vias de reparo de dano ao DNA entre queratinócitos normais e linhagens derivadas de cânceres de colo de útero. Representação por Diagramas de Venn do número de genes diferencialmente expressos em cada comparação $(\mathrm{C} 33 \mathrm{~A}=\mathrm{C} 33 \mathrm{~A}$ vs $\mathrm{QPH}$; $\mathrm{SiHa}=\mathrm{SiHa}$ vs $\mathrm{QPH}$; HeLa $=$ HeLa vs $\mathrm{QPH}$ ). Foram considerados apenas genes com fold $>2$ ou fold $<-2$, e $p$-valor $<0,05$.

Observamos que 10 genes das vias de sinalização de dano ao DNA e 9 genes das vias de reparo de dano ao DNA estão diferencialmente expressos entre QPH e as três linhagens tumorais (18 genes diferentes, uma vez que um destes genes é 
comum aos dois arrays). Estes genes estão listados nas Tabelas 2 e 3. Além disso, as linhagens C33A e SiHa apresentaram outros 42 e 43 genes, respectivamente, da via de sinalização de dano ao DNA, diferencialmente expressos quando comparadas aos QPH, sendo 35 deles em comum (Figura 4-A). Quando analisamos genes pertencentes às vias de reparo de dano ao DNA, C33A e SiHa apresentaram, respectivamente, outros 43 e 27 genes diferencialmente expressos, sendo 16 desses genes em comum (Figura 4-B). Interessantemente, observamos que apenas 3 genes (CCNO, PNK e TREX1) de todos os genes analisados estavam diferencialmente expressos entre as duas linhagens HPV positivas e queratinócitos normais.

Tabela 2 - Nome e alteração relativa no nível de expressão (fold: amostra/controle) dos 10 genes envolvidos na sinalização de dano ao DNA diferencialmente expressos entre as linhagens de câncer do colo do útero e QPH (controle).

\begin{tabular}{|c|c|c|c|c|c|c|}
\hline & C33 & & $\mathrm{SiHa}$ & & HeLa & \\
\hline Genes & Fold & $95 \% \mathrm{CI}$ & Fold & $95 \% \mathrm{Cl}$ & Fold & $95 \% \mathrm{Cl}$ \\
\hline FANCG & 4,349 & $(1.04-7.64)$ & 4,078 & $(0.69-7.47)$ & 3,704 & $(0.28-7.13)$ \\
\hline GTSE1 & 9,305 & $(5.95-12.66)$ & 4,872 & $(3.20-6.54)$ & 3,943 & $(2.58-5.30)$ \\
\hline IGHMBP2 & 4,740 & $(1.25-8.23)$ & 9,391 & $(1.30-17.48)$ & 3,255 & $(0.92-5.59)$ \\
\hline LIG1 & 13,038 & $(0.00001-26.72)$ & 15,293 & $(0.00001-32.80)$ & 9,776 & $(0.00001-19.99)$ \\
\hline MAP2K6 & 10,813 & $(0.00001-25.10)$ & 29,678 & $(0.00001-61.90)$ & 36,527 & $(0.00001-78.28)$ \\
\hline MRE11A & 3,592 & $(0.45-6.73)$ & 4,761 & $(0.32-9.20)$ & 4,167 & $(0.46-7.88)$ \\
\hline NTHL1 & 5,127 & $(2.99-7.26)$ & 3,625 & $(1.77-5.48)$ & 3,401 & $(1.66-5.14)$ \\
\hline RAD51 & 2,831 & $(1.68-3.98)$ & 6,656 & $(3.55,9.76)$ & 3,645 & $(1.73-5.56)$ \\
\hline RAD9A & 6,153 & $(1.38-10.92)$ & 12,278 & $(1.65-22.91)$ & 4,656 & $(1.05-8.26)$ \\
\hline SMC1A & 8,025 & $(1.52-14.53)$ & 15,540 & $(2.44-28.64)$ & 4,678 & $(0.10-9.25)$ \\
\hline
\end{tabular}

Estes resultados demonstram que há um grande número de genes diferencialmente expressos entre as células primárias (QPH) e as linhagens tumorais. No entanto, essa diferença varia quando consideradas as diferentes linhagens tumorais e o conjunto de genes analisados. Esse resultado é reforçado ao observarmos o agrupamento das diferentes linhagens analisadas no estudo levando em consideração dados da expressão dos 84 genes presentes em cada array (Figura 6). 
Tabela 3 - Nome e alteração relativa no nível de expressão (fold: amostra/controle) dos 9 genes envolvidos na sinalização de reparo de dano ao DNA diferencialmente expressos entre linhagens de câncer do colo do útero e QPH (controle).

\begin{tabular}{ccccccc}
\hline & C33 & \multicolumn{3}{c}{ SiHa } & HeLa & \\
\hline Genes & Fold & 95\% Cl & Fold & 95\% Cl & Fold & 95\% Cl \\
BRIP1 & 4,195 & $(2.86-5.53)$ & 2,389 & $(1.59-3.18)$ & 2,070 & $(1.33-2.81)$ \\
DMC1 & $-6,210$ & $(0.05-0.27)$ & 9,059 & $(3.04-15.08)$ & $-3,019$ & $(0.13-0.53)$ \\
EX01 & 6,113 & $(4.18-8.05)$ & 5,143 & $(3.96-6.33)$ & 3,0161 & $(2.04-3.99)$ \\
FEN1 & 4,709 & $(0.66-8.76)$ & 4,436 & $(0.50-8.38)$ & 4,246 & $(0.57-7.92)$ \\
MSH4 & 17,53 & $(8.02-27.05)$ & $-2,994$ & $(0.00001-0.91)$ & $-4,554$ & $(0.06-0.38)$ \\
RAD51 & 2,387 & $(1.18-3.60)$ & 4,854 & $(2.26-7.45)$ & 2,328 & $(1.15-3.51)$ \\
RAD54L & 2,279 & $(1.68,2.88)$ & 3,425 & $(1.96-4.89)$ & 2,607 & $(1.84-3.38)$ \\
RPA1 & 2,780 & $(2.15-3.41)$ & 5,061 & $(2.28-7.84)$ & 2,405 & $(1.03-3.78)$ \\
TREX1 & $-2,476$ & $(0.35-0.46)$ & 4,561 & $(2.97-6.15)$ & 2,961 & $(2.46-3.46)$ \\
\hline
\end{tabular}

(fold > 2 ou fold < -2; p-valor < 0,05); Grupo controle QPH

\section{A) Vias de sinalização de dano ao DNA}

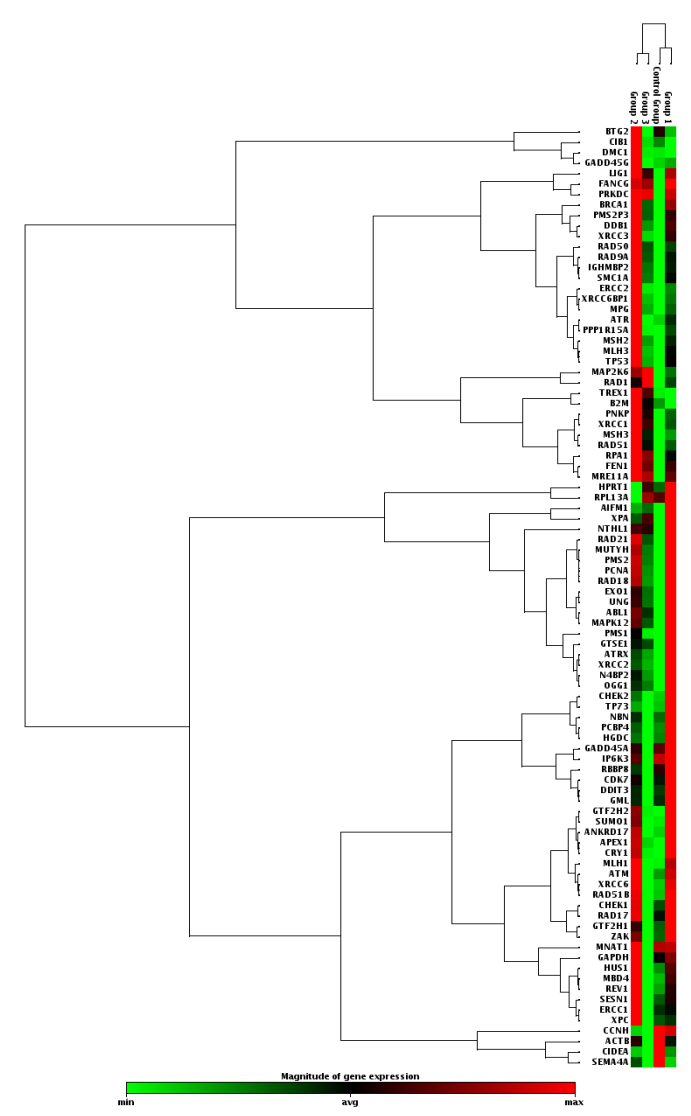

B) Vias de reparo de dano ao DNA

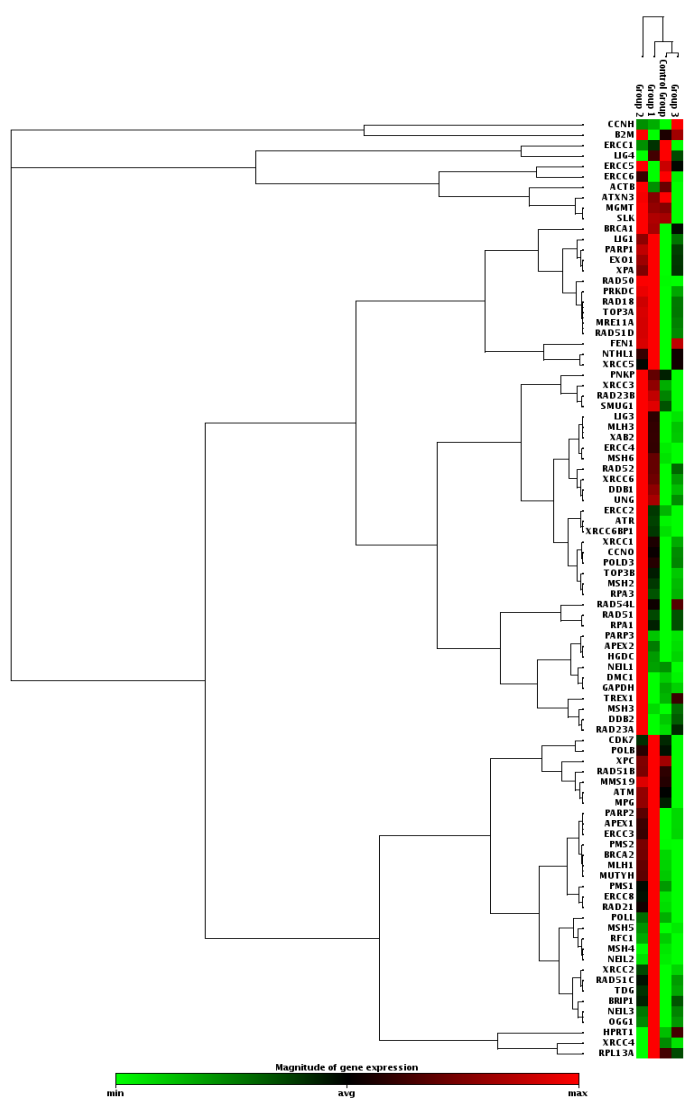

Figura 6 - Agrupamento das amostras em função do padrão de expressão de 84 genes envolvidos nas vias de sinalização de dano ao DNA (A) e 84 genes envolvidos no reparo de dano ao DNA (B). São apresentados dados relativos do nível de expressão dos genes analisados entre as culturas estudadas [Grupo controle (QPH), Grupo 1 (C33), Grupo 2 ( $\mathrm{SiHa}$ ) Grupo 3 (HeLa)]. O vermelho indica alta expressão gênica e o verde baixa expressão. 


\subsection{Análise da expressão de genes das vias de reparo de dano ao DNA em linhagens derivadas de tumores do colo do útero}

Em linhagens tumorais o padrão de expressão de diversos genes pode ser modificado como consequência de diferentes alterações sofridas pela célula durante o processo de transformação. Além disso, estas podem acumular mutações e outras alterações ao longo do período de manipulação em cultura. Visto que os queratinócitos primários humanos utilizados neste estudo foram mantidos em cultura por um número baixo de passagens e, provavelmente, não acumularam alterações importantes neste período, resolvemos eliminar-los da comparação e manter apenas as linhagens tumorais. Assim, realizamos uma nova análise dos dados comparando o padrão de expressão gênica da linhagem tumoral HPV negativa ao das linhagens HPV positivas. A figura 7 apresenta um diagrama com a quantidade de genes diferencialmente expressos entre as diferentes linhagens tumorais, considerando-se somente os que apresentaram p-valor menor de 0,05 e um fold maior que 2 ou menor que -2 .

Entre os 84 genes envolvidos nas vias de sinalização de dano ao DNA 38 apresentaram expressão diferencial com significância estatística (fold > 2 ou fold < 2; p-valor < 0,05) entre a linhagem C33A e HeLa, 17 genes apresentaram expressão diferencial entre as linhagens C33A e SiHa. Quatro (4) dos genes diferecialmente expressos identificados são comuns entre as linhagens HPV positivas. Da mesma maneira, dos 84 genes envolvidos no reparo do dano ao DNA, 43 apresentaram expressão diferencial entre C33A e HeLa, 14 entre C33A e SiHa, sendo que desses genes 7 apresentam expressão diferencial em comum entre as duas linhagens HPV positivas quando comparados com C33A (Figura 7). 


\section{A) Vias de sinalização de dano ao DNA}

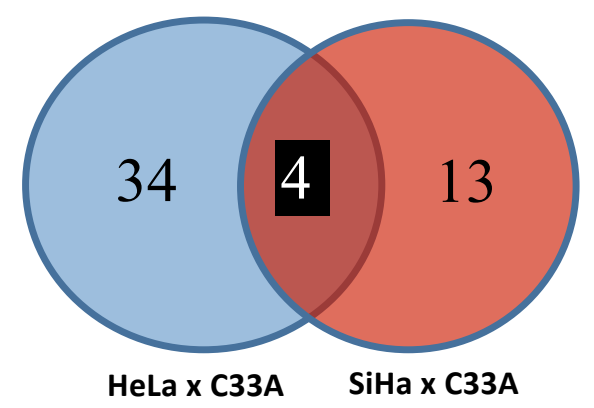

B) Vias de reparo de dano ao DNA

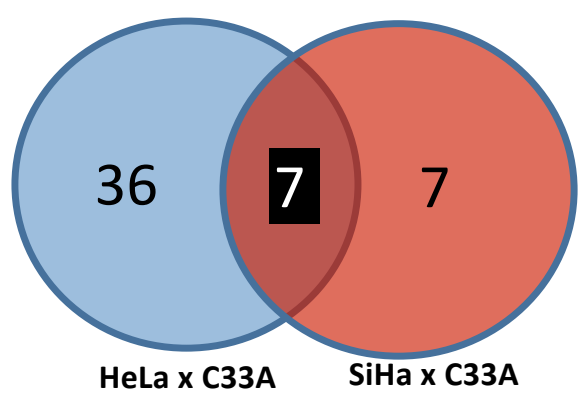

Figura 7 - Comparação da expressão de genes de vias de reparo de dano ao DNA entre linhagens de câncer de colo de útero HPV negativa (C33A) e positivas (SiHa e HeLa). Representação por Diagramas de Venn do número de genes diferencialmente expressos em cada comparação (SiHa vs C33A; HeLa vs C33A) (fold $>2$ ou fold $<-2$; $p$-valor $<0,05$ ).

Em conjunto, observamos que os genes avaliados apresentaram variações na sua expressão em cada linhagem tumoral do colo do útero HPV positiva quando comparada à linhagem HPV negativa. Entretanto, identificamos 9 genes envolvidos nas vias de reparo de dano ao DNA (CHEK2, DMC1, ERCC5, MSH4, NBN, NEIL2, OGG1, TREX1, XRCC2) que diferenciam as linhagens HeLa e SiHa da linhagems HPV negativa C33A. Conforme esperado a variação do padrão de expressão (aumento ou diminuição) destes genes nas duas linhagens HPV positivas foi semelhante. Estes resultados estão apresentados nas Tabelas 4 e 5.

Tabela 4 - Nome e alteração relativa no nível de expressão (fold: amostra/controle) dos 4 genes envolvidos na sinalização de dano ao DNA diferencialmente expressos entre as linhagens de derivadas de tumores do cólo do útero HPV positivas e a linhagem HPV negativa (controle).

\begin{tabular}{ccccc}
\hline & HeLa & \multicolumn{3}{c}{ SiHa } \\
\hline Genes & Fold & $95 \% \mathbf{C l}$ & Fold & $\mathbf{9 5 \%} \mathbf{C l}$ \\
CHEK2 & $-12,087$ & $(0.00001-0.21)$ & $-3,038$ & $(0.16-0.50)$ \\
NBN & $-23,730$ & $(0.00001-0.21)$ & $-2,303$ & $(0.24-0.63)$ \\
TREX1 & 15,011 & $(7.06-22.96)$ & 22,627 & $(12.12-33.13)$ \\
XRCC2 & $-4,548$ & $(0.07-0.37)$ & $-2,303$ & $(0.28-0.49)$ \\
\hline
\end{tabular}

(fold > 2 ou fold < -2; p-valor < 0,05); Grupo controle C33A 
Tabela 5 - Nome e alteração relativa no nível de expressão (fold: amostra/controle) dos 7 genes envolvidos na sinalização de reparo do dano ao DNA diferencialmente expressos entre as linhagens derivadas de tumores do cólo do útero de câncer HPV positivas e a linhagem HPV negativa (controle).

\begin{tabular}{ccccc}
\hline & HeLa & \multicolumn{3}{c}{ SiHa } \\
\hline Genes & Fold & $\mathbf{9 5 \%}$ Cl & Fold & 95\% Cl \\
\hline DMC1 & 2,0572 & $(1.13-2.99)$ & 56,2585 & $(26.44-86.07)$ \\
\hline ERCC5 & 2,2304 & $(1.48-2.99)$ & 3,5488 & $(2.46-4.63)$ \\
MSH4 & $-79,8562$ & $(0.00-0.02)$ & $-52,5639$ & $(0.00001-0.05)$ \\
NEIL2 & $-8,6498$ & $(0.06-0.18)$ & $-5,8536$ & $(0.06-0.28)$ \\
OGG1 & $-2,270$ & $(0.41-0.47)$ & $-2,162$ & $(0.37-0.55)$ \\
TREX1 & 7,3309 & $(6.22-8.44)$ & 11,2928 & $(7.45-15.14)$ \\
XRCC2 & $-5,5123$ & $(0.14-0.22)$ & $-2,3338$ & $(0.30-0.55)$ \\
\hline
\end{tabular}

(fold > 2 ou fold < -2; p-valor < 0,05); Grupo controle C33A

\subsection{Validação dos dados de expressão gênica por PCR em tempo real}

Visando confirmar os resultados obtidos nos arrays comerciais descritos acima, selecionamos alguns genes para validação por PCR em tempo real. Os mesmos foram escolhidos considerando àqueles com maior diferença de expressão quando comparados ao grupo controle, presença dos mesmos nas diferentes comparações realizadas e com base em dados da literatura. Com base nesses critérios selecionamos os genes RAD51, TREX1, RAD54L e RPA1.

Para a validação dos níveis de expressão dos genes selecionados primers específicos foram desenhados para análise por PCR em tempo real. Primeiramente, os genes foram analisados in silico, e obtivemos primers com aproximadamente 20 nucleotídeos, gerando produtos de amplificação entre 50 e 160 pb, com temperatura de anelamento entre 58 e $64{ }^{\circ} \mathrm{C}$ e com pouca tendência a formar dímeros ou estruturas secundárias. Todos os experimentos foram realizados utilizando o gene $R P L O$ de expressão constitutiva para normalizar os dados obtidos e gerar os valores de expressão relativa pelo método de análise os $2^{-\Delta \Delta C t}$. Os níveis de mRNA das amostras de queratinócitos primários humanos (QPH) foram utilizados como referência. 
Em primeiro lugar, as amostras de RNA total obtidas a partir das culturas celulares foram tratadas com DNase I para eliminar qualquer resto de DNA genômico. Para confirmar a eficácia do tratamento com DNase I realizou-se uma PCR convencional utilizando um par de primer que amplifica uma região intrônica do gene $h M L H-1$ (figura 8-A). Em seguida, foi realizada a etapa de síntese de cDNA por transcrição reversa. Finalmente, a eficiência da síntese de cDNA foi monitorada mediante uma reação de PCR utilizando um par de primer específico para o gene NOTCH2.1. Estes primers reconhecem sequências localizadas em éxons diferentes do gene NOTCH2.1 e amplificam, portanto, de maneira específica DNA sem íntrons (figura 8-B). Os resultados foram analisados por eletroforese em gel de agarose $2 \%$ corado com GelRed e visualisados sob luz ultravioleta.

A)

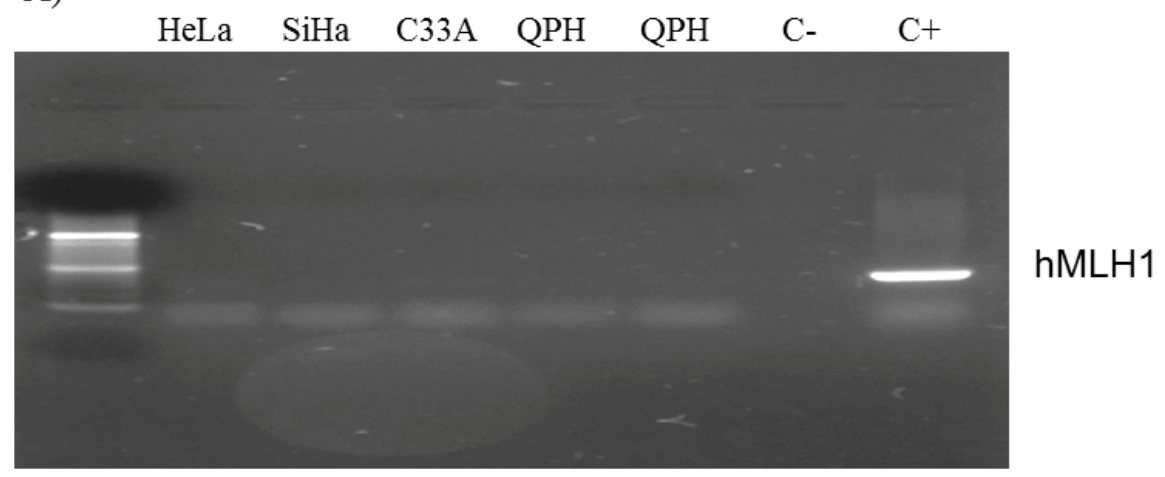

B)

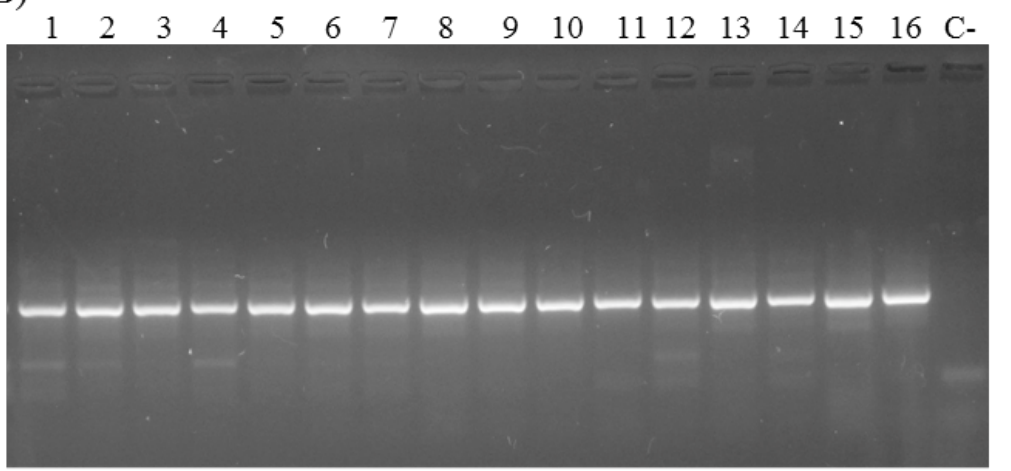

Notch2.1

Figura 8 - Controle da reação de síntese de cDNA. A) A ausência de DNA genômico foi confirmada por PCR realizada com primers para o gene $h M L H-1$ a partir de amostras de RNA tratadas com DNase I. Na figura é mostrado um gel representativo dos resultado obtidos. C- (controle negativo, reação sem amostra); C+ (controle positivo, DNA de HeLa). B) A síntese de cDNA foi analisada por PCR utilizando primers para o gene NOTCH2.1. No gel estão representadas as amostras utilizadas no estudo (1-4 HeLa; 5-8 SiHa; 9-12 C33A; 13-16 QPH) C- (controle negativo, reação sem amostra). As amostras foram aplicadas em gel de agarose $2 \%$ corado com GelRed, submetido a eletroforese, e visualizado sob luz ultravioleta. 
Em primeiro lugar, analisamos os níveis de mRNA para o gene TREX1. Observamos que a expressão de TREX1 está regulada positivamente nas linhagens HPV positivas quando comparadas aos QPH. Por outro lado, a expressão deste gene está regulada negativemente na linhagem tumoral HPV negativa C33A quando comparado ao grupo controle QPH. Esses dados confirmam as observações geradas dos arrays comerciais e sugerem que o aumento da expressão de TREX1 pode estar relacionado à presença do HPV (figura 9).

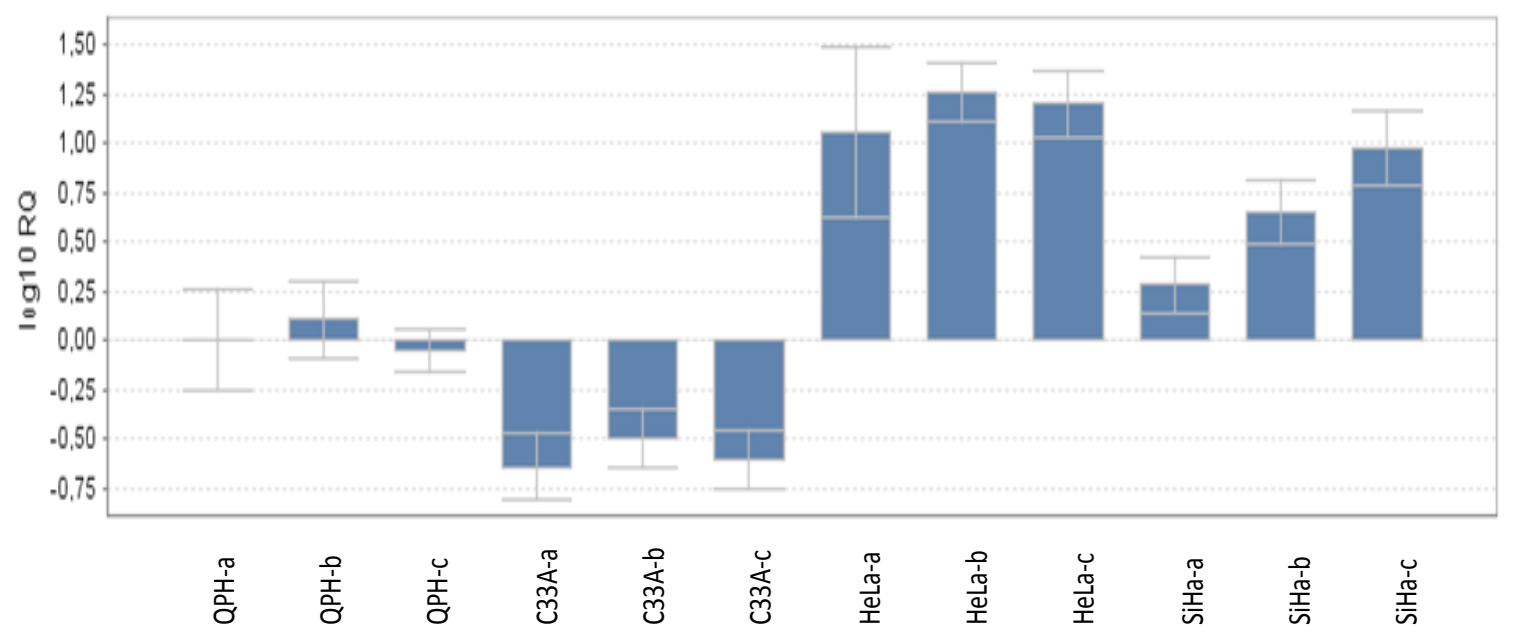

Figura 9 - Análise dos níveis de expressão relativa de RNAm para o gene TREX1 nas linhagens de QPH, SiHa, HeLa e C33A: O nível de expressão gênica foi avaliado em ensaios de qPCR, utilizando $50 \mathrm{ng}$ de cDNA, 20nM de primers e com temperatura de anelamento de $62{ }^{\circ} \mathrm{C}$. A expressão do gene constitutivo RPLO foi utilizada para normalizar os dados de expressão relativa e gerar os cálculos comparativos. O gráfico em escala logarítmica mostra as médias de expressão e os desvios padrão das triplicatas das amostras utilizadas.

Para determinar se existe relação entre a expressão de TREX1 e a expressão das proteínas E6 e E7 de HPV analisamos os níveis desse gene em amostras de cDNA obtidas a partir de culturas organotípicas de QPH que expressam os genes E6 e E7 de HPV11 e HPV16, vírus de baixo e de alto risco oncogênico, respectativamente. O sistema convencional de cultura de QPH em monocamada seleciona aquelas células capazes de proliferar. Por outro lado, o sistema de cultura organotípica recapitula o programa de diferenciação dos epitélios. Assim, constitui uma ferramenta fundamental para o estudo dos mecanismos de transformação celular mediados por HPV, uma vez que o ciclo viral está estritamente relacionado ao programa de diferenciação do epitélio (Chow e Broker, 1997). 
Amostras de RNA total das culturas utilizadas foram obtidas e analisadas por qPCR. Em uma primeira análise, as amostras que expressavam as proteínas E6 e E7 de HPV apresentaram um maior valor do Ct indicando uma diminuição da expressão de TREX1 quando comparadas aos seus controles da transfecção (vetores pLXSN e pBABE) (figura 10). Entretanto, quando analisamos a curva de dissociação da reação de amplificação para TREX1, observamos que as amostras controle ( $\mathrm{pLXSN}$ e pBabe), apresentavam dois picos de dissociação próximos de 75 e $82{ }^{\circ} \mathrm{C}$. Isto pode indicar a formação de primer dimers ou a amplificação de alguma sequência inespecífica, contradizendo os estudos prévios in silico (figura 11). Assim, acreditamos que os valores de Ct obtidos para das amostras não podem ser considerados parâmetros para comparação da expressão de mRNA.

Visando esclarecer este resultado contraditório resolvemos observar diretamente o produto da qPCR para TREX1. Assim, um mesmo volume de cada amostra da reação de $\mathrm{qPCR}$ foi aplicado em um gel de agarose seguido da eletroforese. Com isso, observamos uma banda do tamanho esperado para o produto de amplificação de TREX1 em todas as amostras. Esta banda parece ser mais intensa no caso das amostras de QPH com E6 e E7 de HPV11 e HPV16, quando comparados com seus respectivos controles e bem intensa na amostra derivada da linhagem SiHa quando comparada com QPH (figura 12). No entanto, esses dados não podem ser considerados conclusivos. Assim, decidimos validar definitivamente as observações realizadas estudando os níveis da proteína TREX1 (ver abaixo). 


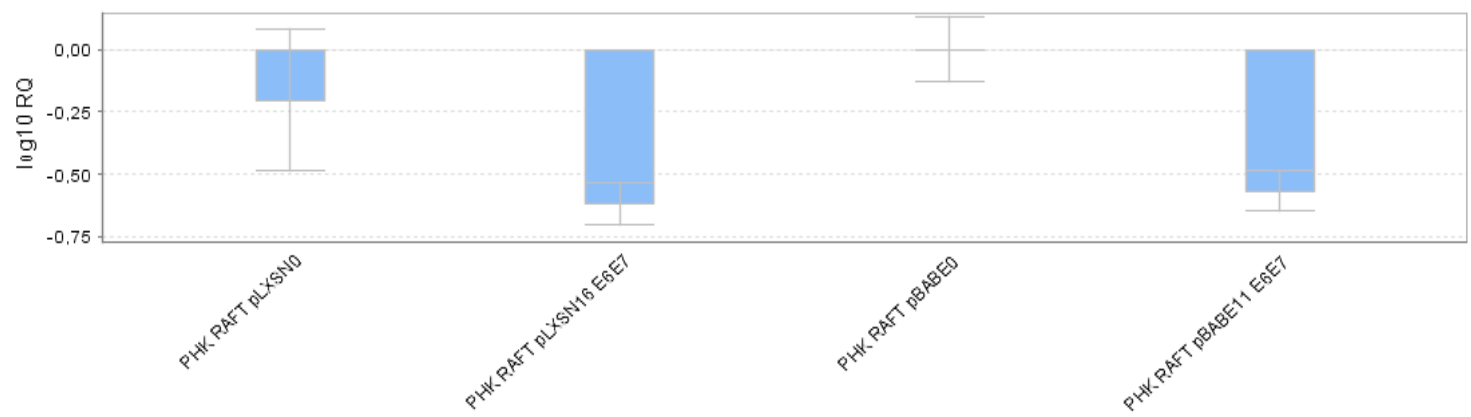

Figura 10 - Análise dos níveis de expressão relativa de RNAm correspondente ao gene TREX1 em culturas organotípicas de QPH pLXSN, QPH 16E6E7, QPH pBABE, QPH 11E6E7. O nível de expressão gênica foi avaliado em ensaios de qPCR, utilizando 50ng de cDNA, 20nM de primers e com temperatura de anelamento de $62{ }^{\circ} \mathrm{C}$. A expressão do gene constitutivo $R P L O$ foi utilizada para normalizar os dados de expressão e gerar os cálculos comparativos. O gráfico em escala logarítmica foi gerado utilizando a amostra de QPH transduzido com o vetor pBABE vazio como referência mostrando as médias de expressão e os desvios padrão.

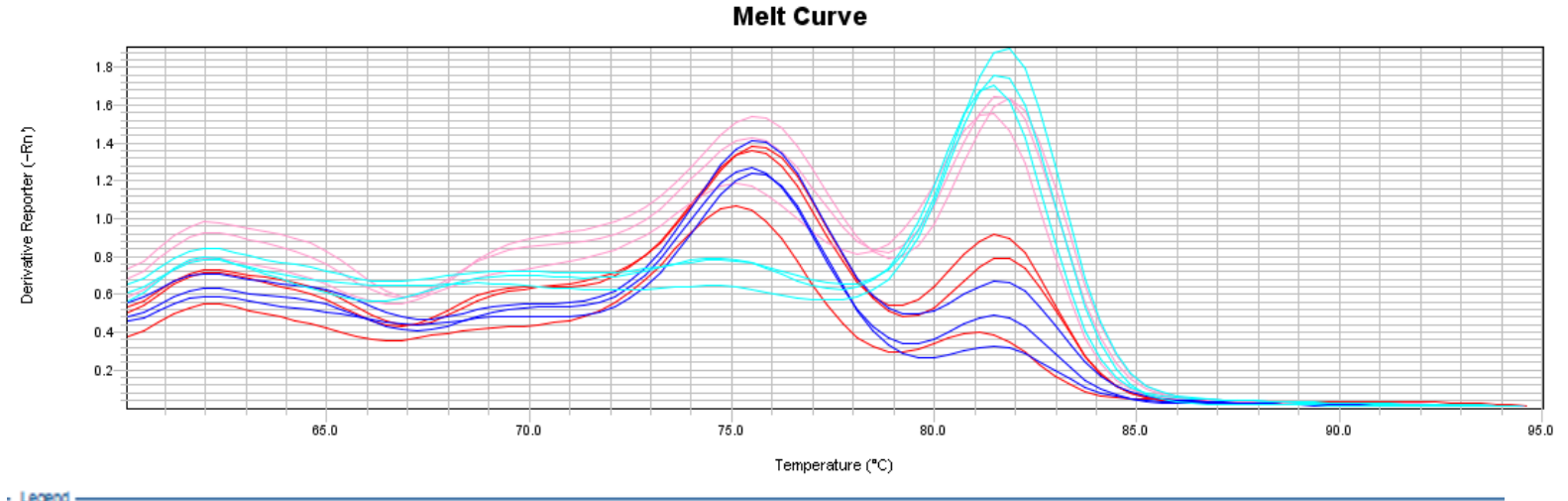

PHKRAFT PLXSN16 E6E7

PHKRAFT pLXSNO PHKRAFT PBABE11 E6E7

PHKRAFT PBABE0

Figura 11 - Curva de dissociação das amostras de cultura organotípicas QPH pLXSN, QPH 16E6E7, $\mathrm{QPH}$ pBABE, QPH 11E6E7 para o gene TREX1. As amostras foram avaliadas em ensaios de qPCR, utilizando $50 \mathrm{ng}$ de cDNA, $20 \mathrm{nM}$ de primers e com temperatura de anelamento de $62^{\circ} \mathrm{C}$.

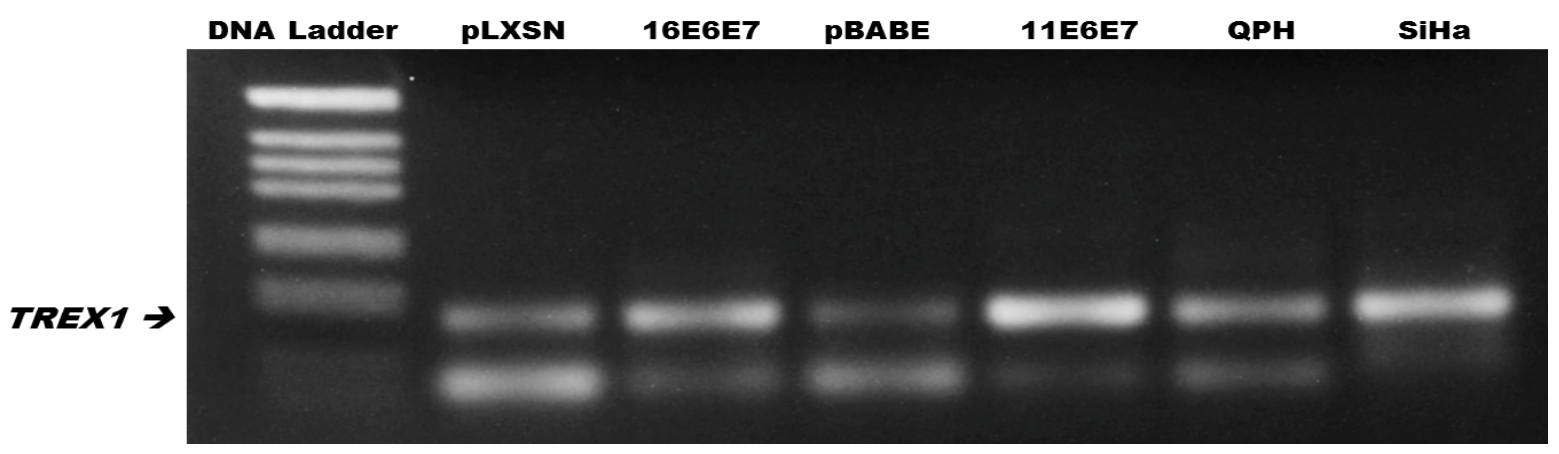

Figura 12 - Análise por eletroforese da reação de qPCR para o gene TREX1 em amostras de culturas organotípicas de QPH transduzidos com os vetores pLXSN, HPV16 E6E7, pBABE e HPV11 E6E7, e de culturas em monocamadas de QPH e SiHa. Foram aplicados $5 \mu \mathrm{L}$ do produto de amplificação em um gel de agarose $1 \%$ corado com GelRed, submetido a eletroforese e visualizado sob luz ultravioleta 
Os dados da expressão do gene RAD51 obtidos a partir dos arrays comerciais descritos anteriormente mostram um aumento da expressão do mesmo nas três linhagens tumorais quando comparada com a expressão em queratinócitos primários. Os resultado obtidos na qPCR confirmaram as observações realizadas nos arrays comerciais (figura 13). No entando, quando analisamos as amostras de QPH transduzidas com os oncogenes do HPV não observamos alterações nos níveis de expressão desse gene. Esses resultados indicam que o aumento da expressão de RAD51 não está associado à expressão aguda dos genes virais e que pode estar vinculado ao processo de transformação celular.

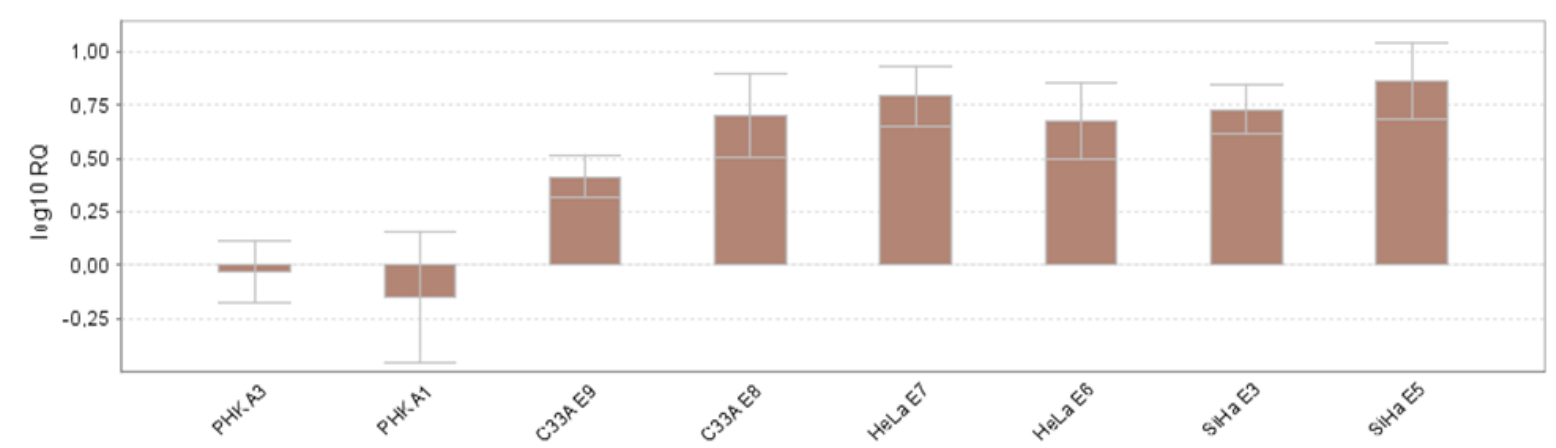

Figura 13 - Análise dos níveis de expressão relativa de RNAm para o gene RAD51 nas linhagens de QPH, SiHa, HeLa e C33A: O nível de expressão gênica foi avaliado em ensaios de qPCR, utilizando $50 \mathrm{ng}$ de cDNA, 20nM de primers e com temperatura de anelamento de $60^{\circ} \mathrm{C}$. A expressão do gene constitutivo RPLO foi utilizada para normalizar os dados de expressão e gerar os cálculos comparativos. O gráfico em escala logarítmica mostra as médias de expressão e os desvios padrão das triplicatas das amostras utilizadas.

A análise da expressão dos genes RPA1 e RAD54L apresentou problemas na padronização das condições de amplifição. Para esses genes, observamos a persistência de múltiplos picos na curva de dissociação do produto de amplificação. Mesmo modificando diferentes parâmetros das condições da reação (temperatura e/ou concentração de primers) não conseguimos melhorar a qualidade do resultado. Portanto, não conseguimos validar os dados de expressão desses genes por qPCR.

Considerando os dados obtidos, resolvemos validar alguns dos resultados através da análise dos níveis de algumas proteínas selecionadas. 


\subsection{Validação dos dados de expressão gênica por análise de proteínas}

A análise de expressão gênica ao nível de RNAm permite determinar o padrão de expressão de genes associados a um processo específico, em nosso caso os mecanismos de reparo de dano ao DNA. No entanto, os níveis de RNAm podem não refletir os níveis da proteína codificada. Além disso, não foi possível padronizar a reação de qPCR para alguns dos primers sintetizados. Assim, resolvemos validar alguns de nossos resultados analisando a expressão de proteínas selecionadas. Para isso, os níveis das proteínas CHEK2, FEN1, LIG1, MAP2K6, MRE11A, PCNA, PNK, RAD51, RAD9, RPA1, SMC1A e TREX1 foram analisados por western blot em extratos protéicos totais obtidos a partir das linhagens tumorais C33A, SiHa e HeLa, e de queratinócitos primários normais ou que expressam as proteínas E6 e E7 de HPV16 (alto risco oncogênico) e HPV11 (baixo risco oncogênico). Os resultados são apresentados na Figura 14. Obverva-se que, na grande maioria, condizem com os resultados obtidos na análise de RNAm descritos anteriormente.

De um modo geral, os níveis das proteínas LIG1, MRE11A, RAD9, SMC1A e TREX1 apresentaram um aumento nas linhagens tumorais quando comparadas a queratinócitos normais ou que expressam genes de HPV. Isto pode indicar que as alterações na expressão desses fatores podem estar associadas a eventos independentes do HPV envolvidos no estabelecimento/progressão tumoral.

Interessantemente, observamos um aumento nos níveis das proteínas FEN1, PCNA, RAD51 e RPA1 nas linhagens tumorais e também em queratinócitos transduzidos com E6 e E7 de HPV16 comparados com o controle. Por outro lado, alterações nos níveis destas proteínas não foram observadas em queratinócitos que expressam as proteínas E6 e E7 de HPV11. Estes dados sugerem que a alteração nos níveis de expressão destes fatores pode ser uma característica de células infectadas por HPV de alto risco oncogênico.

Analisando os níveis da proteína CHEK2 observamos que os mesmos estão aumentados na linhagem HPV negativa (C33A) em relação aos observados nas linhagens HPV positivas (HeLa e SiHa). Isto confirma as observações realizadas ao 
estudar os níveis de mRNA nos arrays (Tabela 4). Interessantemente, os níveis desta proteína estão aumentados em todos os queratinócitos transduzidos incluindo aqueles que apresentam apenas os vetores vazios (Figura 14-A).

A expressão da proteína MAP2K6 foi detectada apenas nas linhagens HeLa e $\mathrm{SiHa}$. Isto pode indicar o envolvimento da proteína em etapas mais tardias do processo de carcinogênese mediado por HPV, uma vez que, ela não é detectada em queratinócitos que expressam E6 e E7 de maneira aguda e nem na linhagem tumoral HPV negativa C33A (Figura14-D). Na análise da expressão do gene PNK observamos que o mesmo estava diferencialmente expresso nas duas linhagens HPV positivas quando comparadas com os queratinócitos normais. Entretanto, ao analisar os níveis da proteína correspondente nas diferentes linhagens celulares, observamos um pequeno aumento da sua expressão em HeLa e nos QPH que expressam os genes E6 e E7 de HPV 11 (figura 14-G).

Ao analisarmos os níveis da proteína TREX1 observamos que os mesmos estão aumentados nas amostras tumorais quando comparadas aos queratinócitos primários. Esta observação é diferente da analise dos níveis de mRNA, onde observamos uma diminuição da expressão do gene na linhagem tumoral HPV negativa (C33A) e um aumento nas linhagens HPV positivas (HeLa e SiHa) quando referenciadas a QPH. No entanto, nas amostras de QPH normais e tranduzidos com genes de HPV observamos uma segunda banda próxima à banda correspondente à proteína TREX1 que está ausente nas amostras das três linhagens tumorais. A natureza desta banda é, até o momento, desconhecida.

Finalmente, determinamos os níveis da proteína PCNA (figura 13-A). Esta proteína está associada à processividade da polimerase $\delta$ e é um antígeno frequentemente utilizado como marcador de proliferação. Sua expressão é regulada pelo fator de transcrição E2F que encontra-se ativo em linhagens com pRb mutado (C33A) ou inativado pela proteína E7 de HPV de alto risco. Conforme esperado, observamos altos níveis de PCNA nas amostras tumorais e em queratinócitos expressando as oncoproteínas E6 e E7 do HPV 16. Por outro lado, os níveis destas 
proteínas não foram alterados em queratinócitos controle ou que expressam a proteína E6 e E7 de HPV11, um tipo de baixo risco oncogênico.

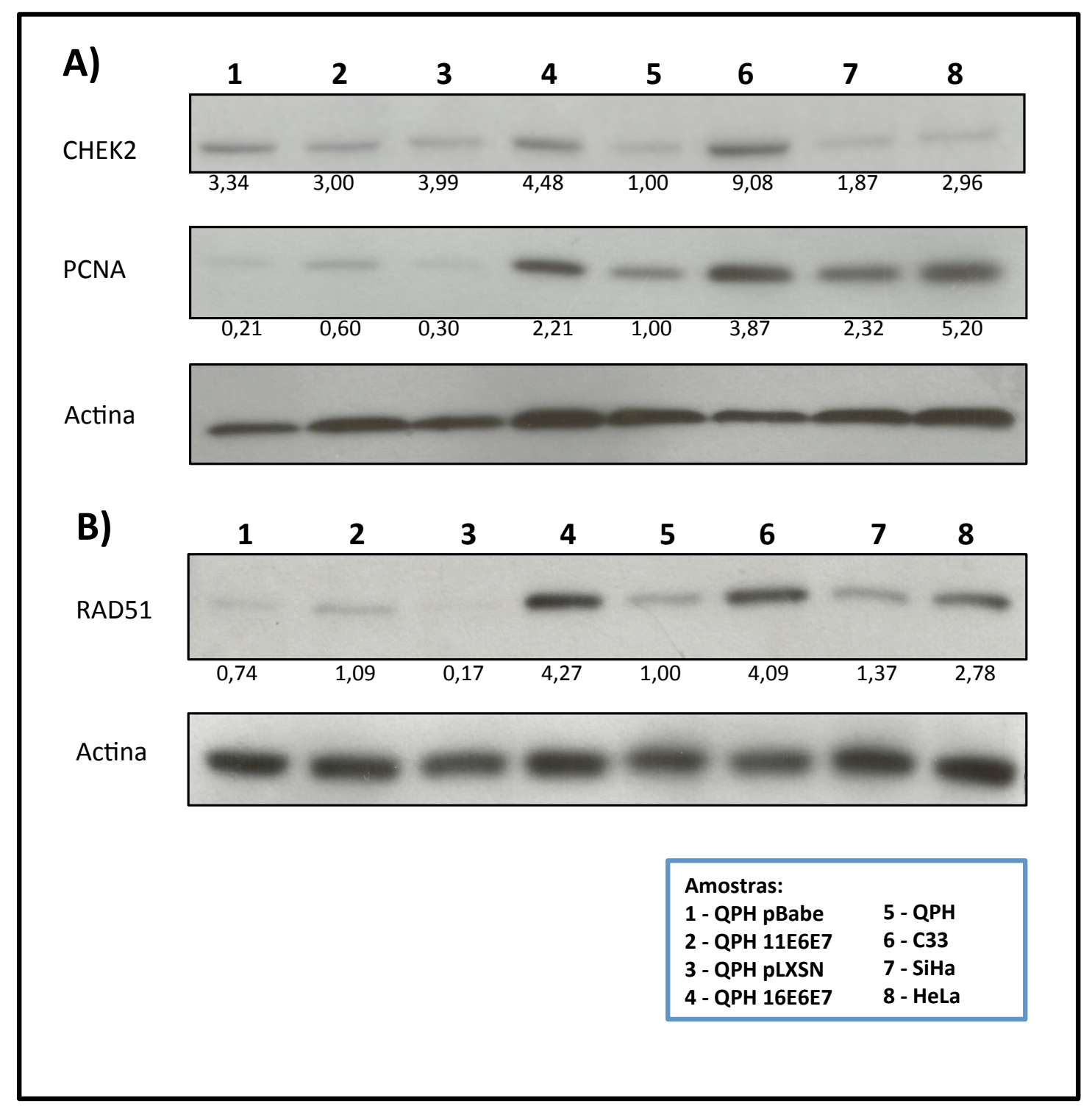




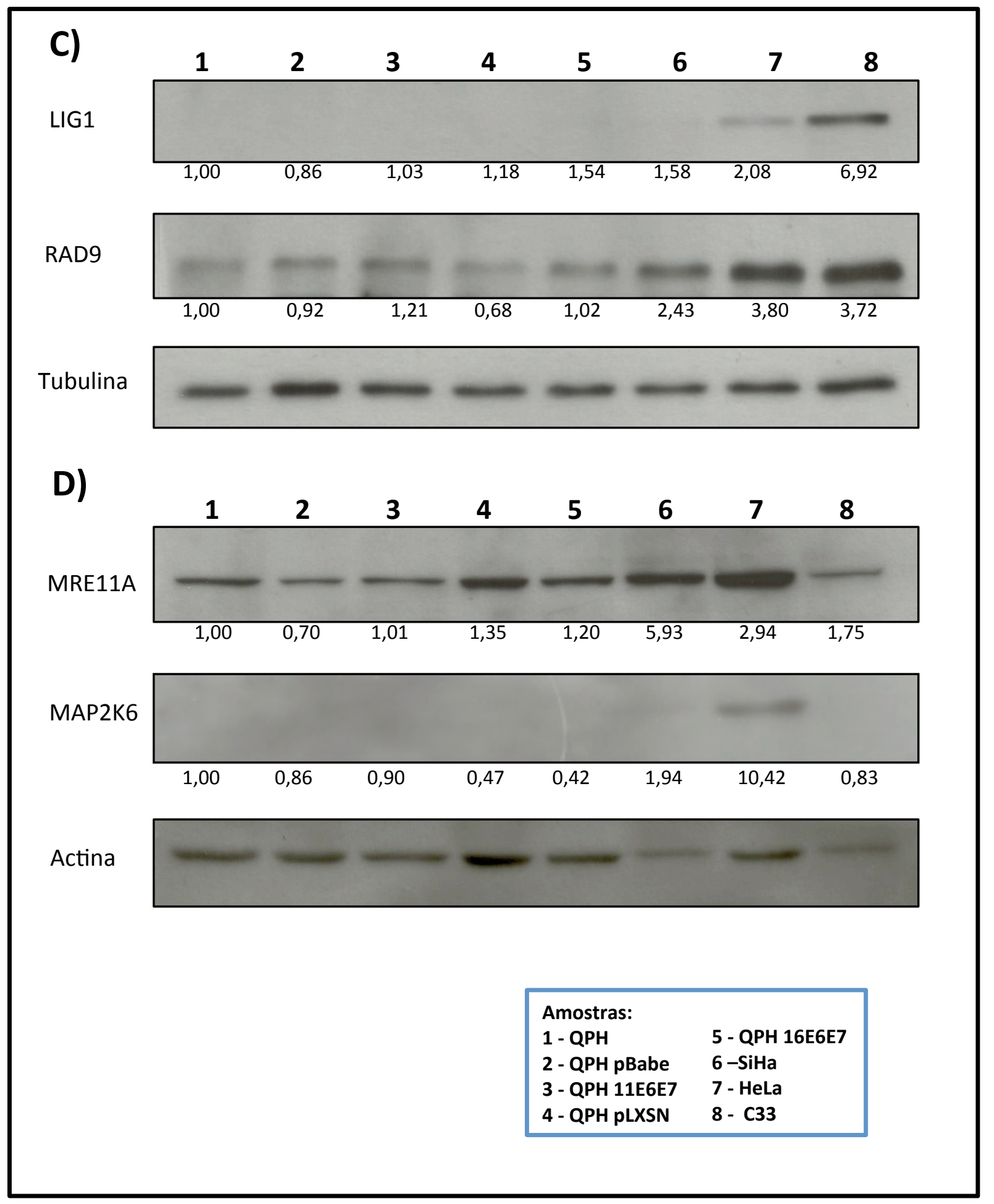




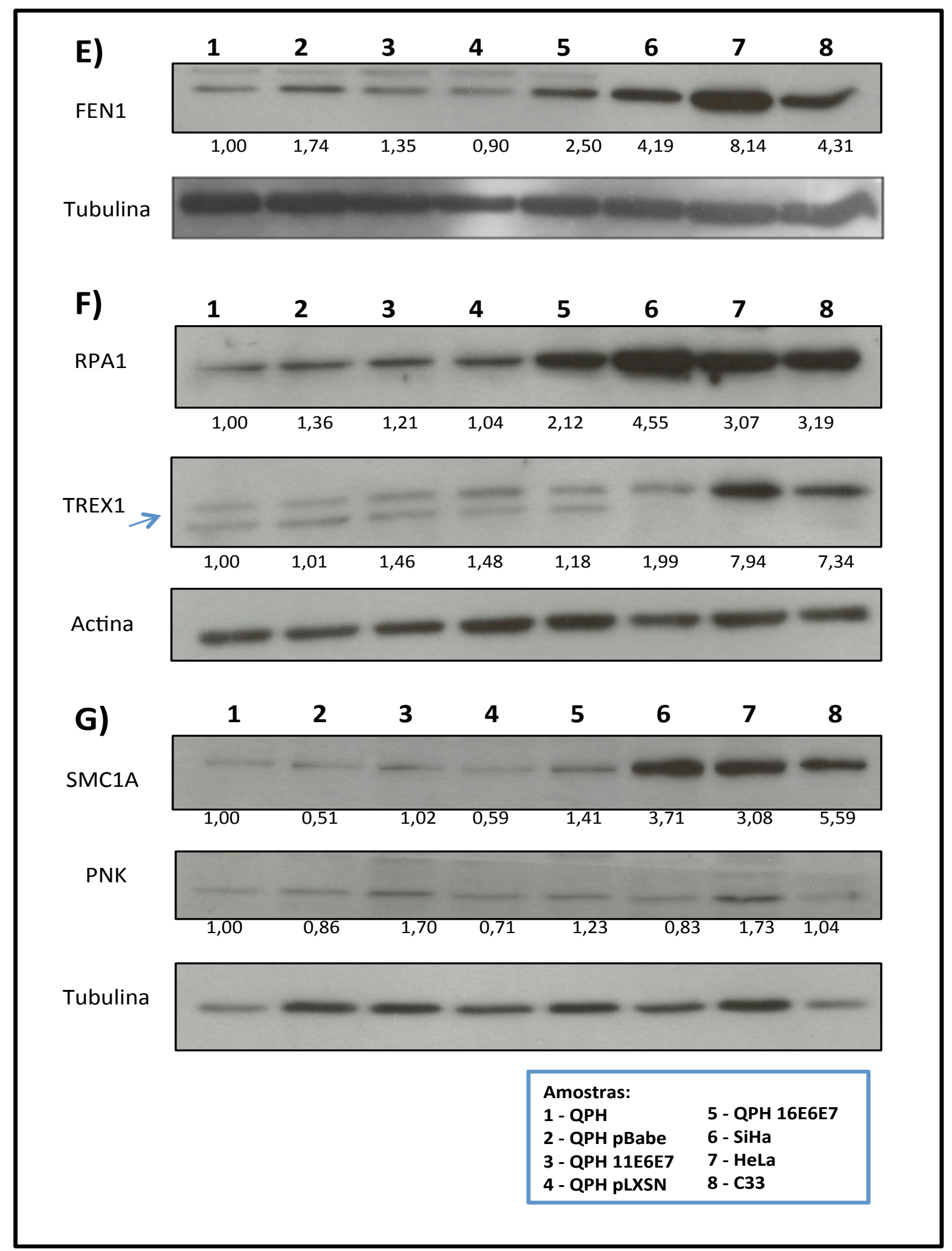

Figura 14: Determinação dos níveis das proteínas CHEK2, FEN1, LIG1, MAP2K6, MRE11A, PCNA, PNK, RAD51, RAD9, RPA1, SMC1A e TREX1 por western blot. Foram utilizados $30 \mu \mathrm{g}$ de extratos protéicos totais obtidos a partir das amostras das culturas celulares QPH pBabe, QPH pBabe 11E6E7, QPH pLXSN, QPH pLXSN 16E6E7, QPH, C33, SiHa e HeLa (A-G). O controle de aplicação de quantidades equivalentes de proteínas foi realizado por detecção de actina (membrana $A, B, D$ e F) ou tubulina (membranas C, E, e G). 


\subsection{Determinação do efeito de proteínas selecionadas na viabilidade celular.}

Os resultados descritos anteriormente mostram que existem vários genes envolvidos nas vias de reparo de dano ao DNA cuja expressão está alterada nas linhagens celulares tumorais. Essas alterações podem ter um papel importante no estabelecimento/progressão de tumores associados à infeção por HPV. Assim, entre os genes envolvidos na vida de reparo do dano ao DNA escolhemos TREX1 e RPA1 para ensaios funcionais. A escolha destes genes foi baseada no fato que os níveis de RPA1 (mRNA e proteína) e TREX1 (proteína) estão aumentados nas linhagens tumorais quando comparadas aos observados em QPH (Tabela 3 e Figura 13). Além disso, dispúnhamos de vetores lentivirais que codificam shRNA (do inglês short hairpin RNA) específicos para estes genes de uma biblioteca comercial para silênciamento de genes envolvidos nas vias de reparo de dano ao DNA. O mecanismo de interferência de RNA baseia-se na capacidade de moléculas pequenas de RNA, complementares a transcritos específicos, reduzir a expressão dos mesmos através da indução de sua degradação (Wang et al., 2011).

Com isso, resolvemos analisar o efeito do silênciamento destes genes na viabilidade das linhagens tumorais. Para isto foram produzidas partículas lentivirais que expressam shRNA para os genes selecionados. Para cada gene foram utlizados pelo menos 4 clones de shRNA diferentes visando selecionar àqueles que atingirem um silênciamento mais eficiente. Estas partículas foram utilizadas para transduzir células HeLa e SiHa. Como controle da especificidade do silênciamento foi utilizado um vetor que codifica uma sequência scramble, sequência de nucleotídeos aleatória sem alvos celulares conhecidos.

Em primeiro lugar analisamos a eficiência do silênciamento atingida com 0 diferentes clones verificando os níveis das proteínas RPA1 e TREX1 nas células silênciadas por western blot. Um exemplo representativo dos resultados obtidos é apresentado na Figura 14. Na mesma, se observa que foram utilizados 5 clones para o silênciamento do gene $\operatorname{RPA1}(\mathrm{A} 7, \mathrm{~A} 8, \mathrm{~A} 9, \mathrm{~A} 10$ e $\mathrm{A} 11)$ e 4 clones para o silênciamento do gene TREX1 (C7, C9, C10 e C11). 
Para o silênciamento do gene RPA1 os clones $\mathrm{A} 8, \mathrm{~A} 10$ e o $\mathrm{A} 11$ mostraram melhores resultados quanto à quantidade de proteína detectada. No entanto, para o gene TREX1 os clones C9, C10 e C11 foram os mais eficazes no silênciamento deste gene (figura 15). Assim, esses clones foram utilizados nos ensaios subsequentes.
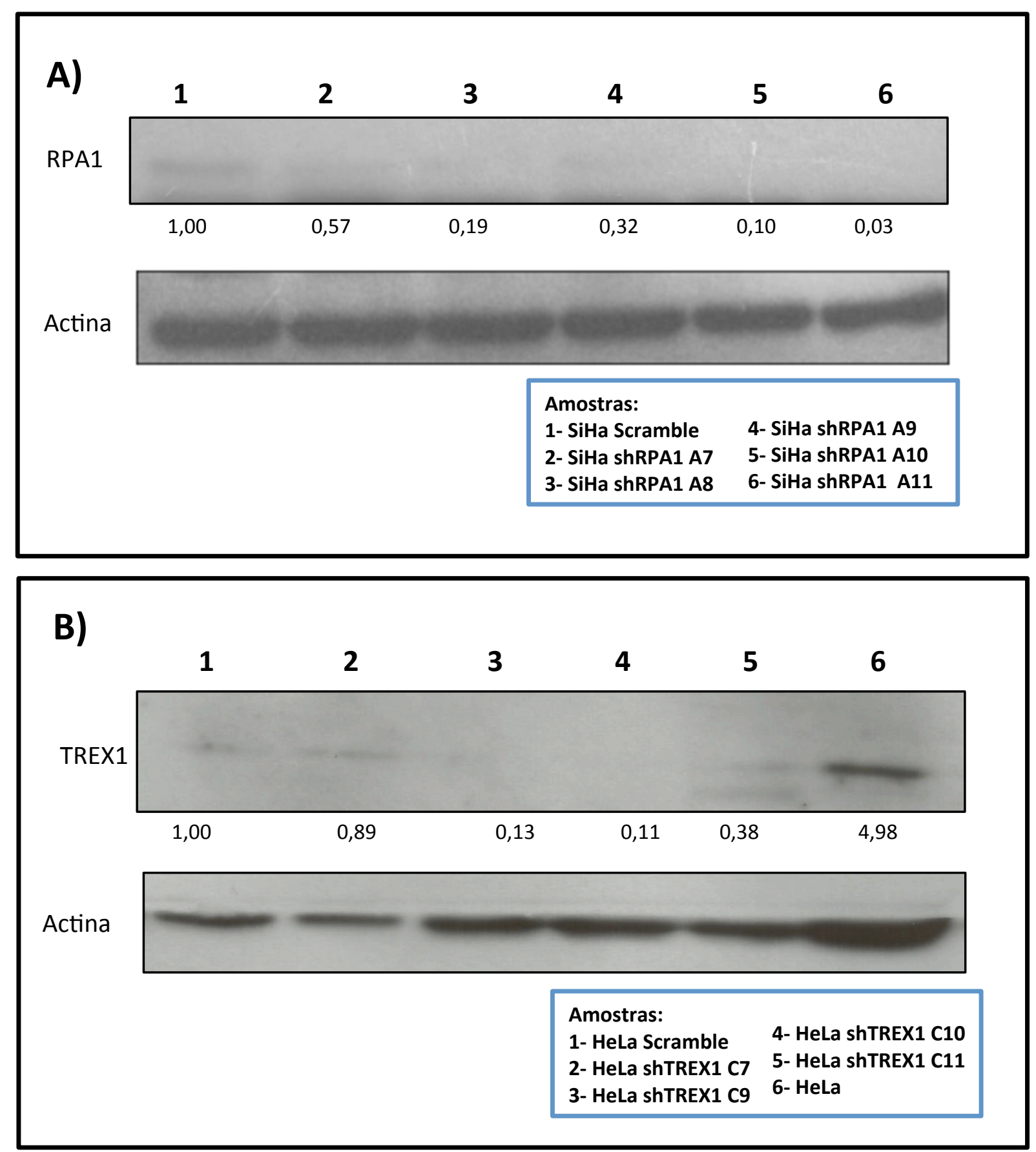

Figura 15 - Determinação por dos níveis das proteínas RPA1 e TREX1 por western blot. Foram utilizados $30 \mu \mathrm{g}$ de extratos protéicos totais obtidos a partir das amostras das culturas celulares da linhagem SiHa Scramble, SiHa shRPA1 A7, SiHa shRPA1 A8, SiHa shRPA1 A9, SiHa shRPA1 A10, SiHa shRPA1 A11, HeLa Scramble, HeLa shTREX1 C7, HeLa shTREX1 C9, HeLa shTREX1 C10, HeLa shTREX1 C11, Hela. O controle de aplicação de quantidades equivalentes de proteínas foi realizado por detecção de actina. 
Após a confirmação do silênciamento dos genes nas linhagens estudadas, avaliamos o efeito no perfil de proliferação/viabilidade celular dessas linhagens. Para isto, células $\mathrm{SiHa}$ foram transduzidas com os clones selecionados (A8, A10 e A11 para RPA1; C7, C9 e C10 para TREX1) e semeadas em placas de 96 poços e após 48 horas a proliferação/viabilidade das mesmas foi avaliada medindo a redução de Alamar blue. Os resultados obtidos na análise da inibição de RPA1 e TREX1 na linhagem SiHa são apresentados na figura 16. Observamos, que a inibição de RPA1 com os clones $\mathrm{A} 8$ e $\mathrm{A} 11$, àqueles que mostraram um silênciamento mais eficiente na avaliação por western blot (figura 15), apresentaram uma diminuição estatisticamente significativa da redução de Alamar blue quando comparadas a células transduzidas com o vetor scramble. Por outro lado, as células $\mathrm{SiHa}$ transuduzidas com os clones C9 e C10 de shRNA para TREX1 tiveram um aumento estatístico da viabilidade quando comparadas ao grupo controle (Figura 16). Interessantemente, entre as linhagens que o gene TREX1 foi silênciado, aquela transduzida com o clone $\mathrm{C} 7$ foi a única que não apresentou um aumento significativo da proliferação/viabilidade. Interessantemente, estas células foram as que apresentaram um silênciamento menos eficiente do gene TREX1 conforme determinado por western blot (Figura 15).

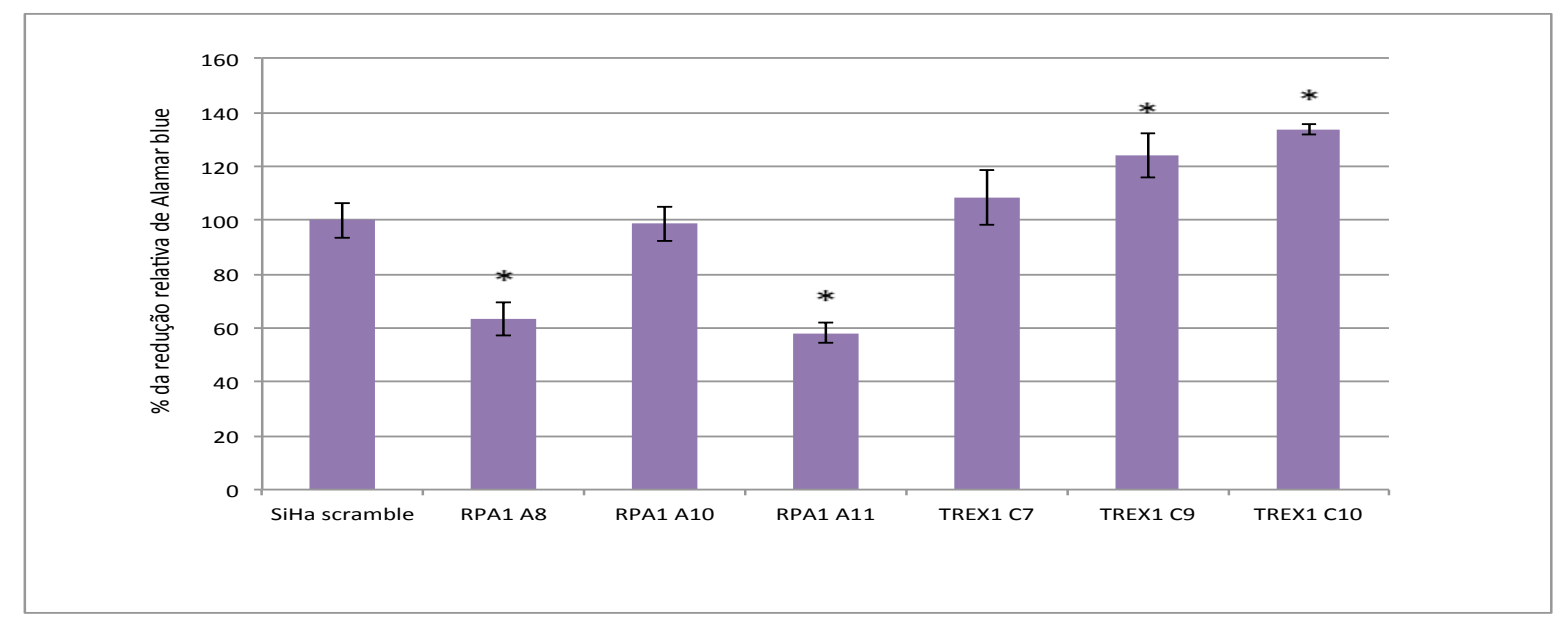

Figura 16 - Determinação do efeito do silênciamento de RPA1 e TREX1 na viabilidade da linhagem $\mathrm{SiHa}$. Células SiHa transduzidas com diferentes clones de shRNA para RPA1 e TREX1 foram semeadas em placas de 96 poços. Após 48 horas a viabilidade/proliferação celular foi determinada verificando a redução de Alamar blue. A diferença na viabilidade/proliferação entre as células transduzidas com os clones A8 e A11 de shRNA para RPA1 e os clones C9 e C10 de shRNA para TREX1 quando comparada às células controle ( $\mathrm{SiHa}$ scramble) foi estatisticamente significativa (teste t Student $p<0,005)$. 
Em uma segunda análise, fomos avaliar se a viabilidade/proliferação celular nas linhagens SiHa e HeLa silênciadas com os clones mencionado acima seguiam o mesmo padrão. As linhagens foram analisada por um período de 5,5 horas com medições da redução de Alamar blue realizadas a cada meia hora. A redução relativa de Alamar blue foi calculada utilizando as células transduzidas com o vetor scramble como referência. A diferença estatística foi determinada para a medições realizadas no tempo de 4 horas (teste t Student $p<0,05$ ) (Figura 16).

Conforme observado anteriormente, as células $\mathrm{SiHa}$ transduzidas com os os clones A8 e A11 de shRNA para silênciamento do gene RPA1 apresentaram viabilidade/prolieferação inferior ao controle transduzido com o vetor scramble interessantemente, o clone A10 apresentou um aumento da viabilidade (figura 17-B). Por outro lado, as linhagens SiHa transduzidas com todos os clones de shRNA para silênciamento de TREX1 apresentaram um aumento significativo da viabilidade comparados com a linhagem controle (figura 17-A). No caso da linhagem HeLa observamos que as células transduzidas com os clones A8 e A11 de shRNA para silênciamento do gene RPA1 também apresentaram uma redução significativa da viabilidade/proliferação (figura 17-D). Diferentemente, observamos uma diminuição significativa da viabilidade no clone $\mathrm{C} 7$ do silênciamento do gene TREX1, entretanto, os outros clones não apresentaram diferenças significativas com o controle de HeLa (figura 17-C). 


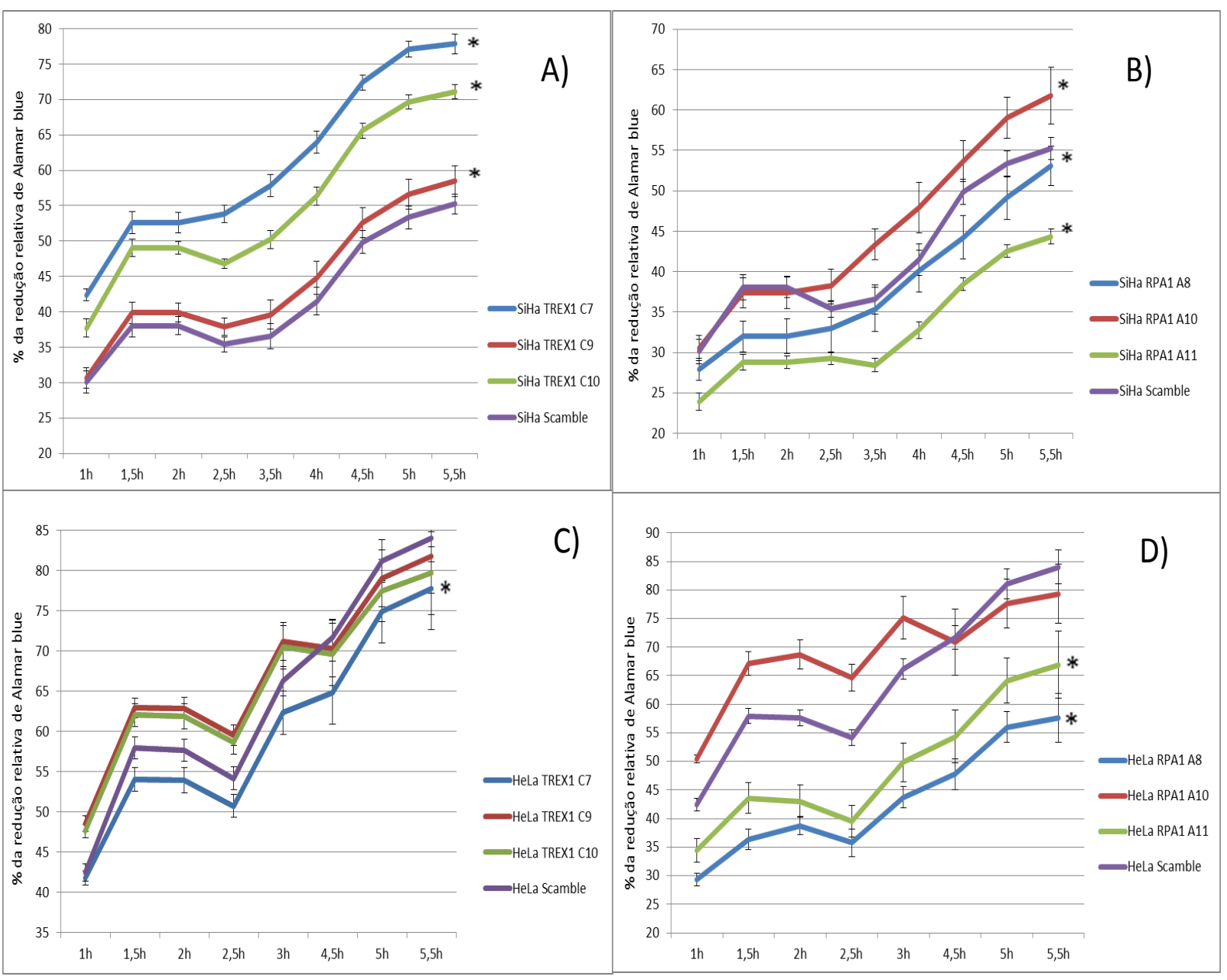

Figura 17 - Determinação do efeito do silênciamento de RPA1 (B e D) e TREX1 (A e C) na viabilidade das linhagens SiHa e HeLa. Células SiHa e HeLa transduzidas com diferentes clones de shRNA para RPA1 e TREX1 foram semeadas em placas de 96 poços. Após 48 horas a viabilidade/proliferação celular foi determinada verificando a redução de Alamar blue por 5,5 horas com medições a cada meia hora. Para a linhagem SiHa a diferença na viabilidade/proliferação entre as células transduzidas com os clones A8 e A11 de shRNA para RPA1 e para todos os clones de shRNA para TREX1 quando comparada às células controle (SiHa scramble) foi estatisticamente significativa. Para a linhagem HeLa a diferença na viabilidade/proliferação entre as células transduzidas com os clones $\mathrm{A} 8$ e $\mathrm{A} 11$ de shRNA para RPA1 quando comparada às células controle ( $\mathrm{SiHa}$ scramble) foi estatisticamente significativa. Não observamos diferenças nas células transduzidas com shRNA para TREX1 (teste $t$ Student $p<0,05$ calculado nos tempos de 1 e 5,5 horas). 


\section{DISCUSSÃO}

A ocorrência de diferentes tipos de dano ao DNA é comum durante a vida de uma célula. As vias de reparo são moduladas por diferentes alterações na molécula do DNA. Esses danos são detectados e sinalizados por diferentes vias efetoras podendo levar a diferentes respostas como a parada do ciclo celular, a morte celular e/ou, quando possível, ao reparo das lesões. De fato, quando não reparados estes danos podem ocasionar o aparecimento de alterações que podem conduzir à morte celular ou ao desenvolvimento de tumores (Sancar et al., 2004). Além disso, alterações em genes envolvidos nos mecanismos de reparo de dano ao DNA ou no seu padrão de expressão podem resultar no acúmulo de alterações genéticas, algumas das quais são importantes para o desenvolvimento do câncer.

As células apresentam diferentes mecanismos para detectar e reparar o DNA danificado. Estes mecanismos encontram-se alterados em muitas células tumorais favorecendo a instabilidade genética (acúmulo de mutações gênicas por defeitos no reparo do DNA e/ou instabilidade cromossômica). Assim, ao longo da evolução de um tumor suas células adquirem alterações genéticas que podem levar ao aumento de expressão ou ao ganho de atividade de proto-oncogenes e/ou à perda de função de genes supressores de tumor. Potencialmente, as células que carregam estas alterações podem apresentar vantagem seletiva em termos proliferativos e adquirir alterações fenotípicas como a capacidade de invadir novos tecidos e órgãos.

O objetivo principal do presente estudo foi analisar o efeito da infecção por HPV e a expressão de seus oncogenes na expressão de genes associados aos mecanismos de reparo de dano ao DNA. Para isso analisamos o padrão de expressão de 135 genes envolvidos nas vias de reparo de dano ao DNA em linhagens derivadas de tumores do colo do útero e queratinócitos normais. As linhagens transformadas utilizadas derivam de um tumor HPV-negativo (C33A), um tumor positivo para HPV16 ( $\mathrm{SiHa}$ ) e um tumor positivo para HPV18. Nossos resultados mostram que existe um grande número de genes diferencialmente expressos entre as linhagens HPV positivas e queratinócitos normais. De fato, identificamos 18 que estão diferencialmente expressos entre as três linhagens 
tumorais analisadas, quando comparadas a queratinócitos normais (Tabelas 2 e 3). Esta observação sugere que alterações na expressão desses genes podem ter um papel na história natural do câncer do colo do útero.

Por outro lado, ao analisar comparativamente o padrão de expressão dos genes em estudo entre as linhagens tumorais obtivemos resultados inesperados. Por exemplo, observamos que a linhagem HeLa apresentou menos genes diferencialmente expressos quando comparada a queratinócitos normais do que as outras linhagens tumorais. Assim, as linhagens SiHa e C33A apresentaram grandes diferenças no padrão de expressão de genes envolvidos com as vias de reparo de dano ao DNA quando comparadas com QPH. Interessantemente, muitos dos genes diferencialmente expressos eram comuns às duas linhagens. De fato, em nosso estudo identificamos apenas 3 genes (CCNO, PNK e TREX1) que diferenciam simultaneamente as duas linhagens HPV positivas dos queratinócitos normais. Em nossas análises, também observamos uma diminuição na expressão dos genes MSH4, NBN, NEIL2, OGG1 e XRCC2 nas duas linhagens HPV positivas quando comparadas com a linhagem HPV negativa C33A. Em um estudo recente, Bajpai e colaboradores (2013) visando estabelecer uma relação na expressão de proteínas envolvidas com o reparo do dano ao DNA demostraram, em amostras de pacientes, que os níveis de transcritos e de suas respectivas proteínas XRCC1, ERCC2, ERCC4, ERCC1 foram inferiores em amostras de câncer de colo de útero e em lesões escamosas intraepiteliais (SIL) em comparação aos pacientes controles. Em conjunto, estes dados indicam que nem a presença de HPV nem o tipo de HPV presente estão associados a alterações específicas nas vias analisadas. Isto pode ser devido à existência de diferenças nos mecanismos de transformação celular exibidas por tipos diferentes de HPV, a diferenças inerentes ao mecanismo de evolução tumoral em cada indivíduo ou ao momento do desenvolvimento da doença em que o estudo foi realizado.

A pesar dos comentários realizados anteriormente as diferenças observadas entre linhagens HPV positivas chamam a atenção pelos fatos semelhantes terem sidos descritos previamente. Por exemplo, em um estudo que analisou o efeito da inibição sistemática de quinases na viabilidade celular foi observado que o conjunto 
de quinases do qual a linhagem HeLa dependia para se manter viável era bem diferente do grupo requerido pela linhagem SiHa. Interessantemente, nesse estudo a linhagem CasKi, outra linhagem derivada de um tumor de colo de útero e que é positiva para HPV16, apresentou um comportamento muito semelhante ao de HeLa (Baldwin et al., 2008).

Uma observação interessante é que ao analisarmos as linhagens tumorais identificamos 9 genes envolvidos na via de reparo do dano ao DNA cujo padrão de expressão diferencia as linhagem HPV positivas da linhagem HPV negativa. Esta observação sugere que as alterações na expressão destes genes podem estar relacionadas à expressão de genes virais específicos além de serem bons candidatos para estudo. Esses resultados foram confirmados na análise dos níveis proteicos de CHEK2, mas não foram confirmados para TREX1 (Tabelas 4 e 5; Figura 14). A linhagem C33A é uma das poucas linhagens derivada de tumores do colo do útero que é negativa para HPV. Como principal característica genética esta linhagem apresenta uma mutação no codon 273 do gene p53. Além disso, esta linhagem apresenta alterações no exon 20 do gene que codifica para a proteína do retinoblastoma (Scheffner et al., 1991). Esta observação sugere que a alteração na expressão/atividade de alguns genes é muito importante na gênese do câncer de colo uterino, mesmo nos casos raros em que a presencia de HPV não é detectada. Isto poderia explicar parcialmente as poucas diferenças detectadas entre linhagens tumorais HPV-positivas e as células C33A. Por outro lado, é importante salientar que existem diversos estudos que indicam que a redução dos níveis da proteína p53 mediada pela proteína E6 de HPV de alto risco oncogênico não é funcionalmente equivalente a mutações no gene p53. Em 1999, Butz e colaboradores analisaram a função de ativação da transcrição da proteína p53 endógena de uma série de linhagens celulares de câncer de colo de útero em comparação com linhagens que apresentavam mutações no gene $p 53$. Estes pesquisadores observaram que mesmo na presença da proteína E6 as linhagens HPV positivas são capazes de responder a estímulos genotóxicos com aumento nos níveis de p53, e que isto estava associado ao aumento nos níveis da proteína $\mathrm{p} 21^{\text {waf1/cip1 }}$ e à parada do ciclo. Por outro lado, as células cancerosas que continham mutações no gene p53 não apresentavam proteína p53 endógena funcional e não tinham uma resposta mediada por p53 a 
agentes que danificam o DNA. Além disso, foi observado que o gene GADD45, que é regulado transcricionalmente por p53, pode ser induzido por agentes genotóxicos em linhagens tumorais transformadas por HPV (Butz e cols., 1999). Estes resultados indicam que a presença de sequências de HPV de alto risco não é funcionalmente equivalente à perda de função da proteína p53 através mutações somáticas no gene p53. Portanto, acreditamos que é necessário continuar validando nossos dados para determinar de maneira definitiva são decorrentes da presença do HPV.

Os resultados da análise dos níveis de proteínas envolvidas nas vias de reparo de dano ao DNA, em sua maioria, foram condizentes com os obtidos estudando os níveis de mRNA. Observamos um aumento na expressão das proteínas de FEN1, LIG1, MRE11A, RAD51, RAD9, RPA1, SMC1 nas linhagens tumorais quando comparadas a queratinócitos normais. Além disso, as proteínas FEN1, RAD51 e RPA1 também apresentaram um aumento em queratinócitos transduzidos com os genes E6 e E7 de HPV 16 (alto risco oncogênico). Isto não foi observado em queratinócitos que expressam as proteínas E6 e E7 de HPV11, um tipo de baixo risco oncogênico. Estes dados indicam que as proteínas E6 e/ou E7 de HPV16 possa ter um efeito sobre a expressão destes genes. Por outro lado, os níveis da proteína CHK2 estão diminuídos nas linhagens HPV positivas quando comparados com a linhagem HPV negativa (C33A). Interessantemente, observamos que todos os QPH transduzidos com vetores retrovirais, controle ou expressando genes de HPV, apresentaram níveis elevados desta proteína quando comparados a QPH sugerindo que o processo de infecção pode ter um papel importante na regulação dos níveis deste fator.

Dados na literatura mostram que durante sua propagação o HPV interage com diversos componentes da maquinaria de reparo de dano ao DNA da célula, promovendo ou inibindo a expressão/atividade de proteínas tais como as envolvidas nas vias reguladas por ATM e ATR. Um exemplo dessa interação é observado em sítios de replicação do HPV, na presença de suas proteínas precoces E1 e E2. Essas proteínas podem ativar uma resposta ao dano ao DNA e recrutar proteínas de reparo para centros nucleares específicos onde são, provavelmente, utilizadas para auxiliar na replicação viral. Vários estudos demonstraram que proteínas envolvidas 
na DNA damage response (DDR) celular colocalizam com o complexo de replicação do HPV. As proteínas identificadas incluem aTrip, TOPbp1, fosfo-ATM, fosfo-H2AX, fosfo-p53, CHEK1, CHEK2, PCNA, RPA, NBS1, 53BP1, BRCA1, RAD51, MRE11 e Ku70/80 (Gillespie et al., 2012; Kadaja et al., 2009; Reinson et al., 2013; Sakakibara et al., 2011; Swindle et al.,1999; Wallace, Galloway, 2013). A expressão das proteínas E6 e E7 assegura a existência de um ambiente propício para a replicação do HPV nas camadas suprabasais do epitélio. A proteína E7 é capaz de desregular diversos pontos de controle do ciclo celular, retardando a diferenciação dos queratinócitos, favorecendo a replicação celular contínua e contribuindo ao acúmulo de alterações genéticas. Em circunstâncias normais a proliferação celular descontrolada, fora de contexto, dispararia mecanismos celulares de controle, como a morte celular por apoptose, visando proteger a homeostase do organismo. Para evadir este tipo de resposta celular os HPV codificam a proteína E6 que, principalmente através da degradação/inativação de p53 e ativação da subunidade catalítica da telomerase, contribui ao aumento do tempo de vida dos queratinócitos infectados e torna essas células resistentes à apoptose mesmo na presença de instabilidade genômica. Assim, tal como muitos outros vírus, o HPV manipula a DDR para replicar seu genoma e garantir sua propagação (Wallace, Galloway, 2013).

Nossos resultados mostram a presença de alterações importantes no padrão de expressão de genes e proteínas associados às diferentes vias de reparo de dano ao DNA em linhagens derivadas de tumores do colo do útero, algumas das quais parecem estar relacionadas à presença do HPV. Assim, entre os genes identificados escolhemos TREX1 e RPA1 para ensaios funcionais. O gene TREX1, cuja expressão está aumentada nas linhagens tumorais HPV positivas codifica para a principal DNA exonuclease 3'-5' de células de mamíferos (DNase III). A proteína TREX1 apresenta-se na forma de homodímero e se localiza no citoplasma da célula. Esta proteína se desloca para o núcleo da célula na fase $S$ e em resposta ao estresse genotóxico. Deficiências nessa exonuclease são observadas na síndrome de Aicardi-Goutières e em chilblain lupus (Kavanagh et al., 2008, Lindahl et al., 2009). 
Diferentes estudos têm gerado resultados que relacionam a atividade de TREX1 com a regulação da resposta imune. Por exemplo, Morita e cols. (2004), observaram que camundongos knockout para este gene apresentaram miocardite inflamatória com características autoimunes e reduzido tempo de vida. Outros estudos têm mostrado que esta proteína pode estar envolvida na regulação da resposta a vírus. Por exemplo, foi observado que a proteína de TREX1 é capaz de inibir a resposta imune inata em resposta à infecção pelo vírus HIV1. Acredita-se que TREX1 digira o DNA do HIV na célula infectada o que impede a ativação da resposta mediada por interferon (Morita et al., 2004). Yan e colaboradores (2010) observaram em células T CD4+ de rato e em macrófagos humanos infectados com HIV tipo I a proteína TREX1 está envolvida na evasão da resposta imune através da degradação de produtos da transcriptase reversa viral não ativos e a inibição de via de interferon pela proteína HMGB2. Nestas células o silênciamento do gene TREX1 reativou a via de sinalização por interferon resultando na inibição da replicação do vírus. Em nosso estudo observamos o aumento da expressão de TREX1 nas linhagens tumorais HPV positivas (figura 9) e em culturas organotípicas expressando genes de E6 e E7 (figuras 10, 11 e 12). Assim, resulta tentador especular sobre a possibilidade de estarmos perante mais uma estratégia do HPV para evadir a resposta imune. Um estudo recente conduzido por Hasan e cols. (2013) mostrou que TREX1 está envolvida na regulação de genes antivirais por vias independentes do interferon. Estes autores observaram que a ativação de genes antivirais em células TREX1(-/-) requer a molécula adaptadora STING, a quinase TBK1 e os fatores de transcrição IRF3 e IRF7. Alterações nas vias de sinalização regulada por interferon tipo I tem sido descritas em células infectadas por HPV (Nees et al., 2001; Bachmann et al., 2002; Boccardo et al., 2010). Além disso, a inibição da atividade transcricional de IRF3 por E6 de HPV16 e a diminuição nos níveis de TBK1 em células que expressam as proteínas E6 e E7 de HPV16 têm sido descritas (Ronco et al., 1998 e dados não publicados de nosso laboratório). No presente estudo observamos que o silênciamento do gene TREX1 em células transformadas por HPV induziu a proliferação de células da linhagem SiHa sem afetar as células HeLa. Considerando as informações discutidas acima seria interessante analisar o efeito do silênciamento de TREX1 na expressão de genes responsivos a interferon nas linhagens derivadas 
de tumores de colo de útero e avaliar o efeito do silênciamento no potencial tumorigênico das mesmas.

Outro gene selecionado para a realização de ensaios funcionais foi o RPA1. Este gene codifica uma proteína de ligação primária de ssDNA em eucariotos, essencial para a replicação, reparo e recombinação homóloga do DNA. As funções de RPA1 no metabolismo do DNA são essenciais para a manutenção da estabilidade cromossômica e para a prevenção do aparecimento de tumores. A importância de RPA1 nesses processos é mostrada pelo fato que camundongos knockout para este fator são inviáveis. Além disso, quando apenas um alelo do gene é funcional os animais apresentam elevadas taxas de tumores malignos (Wang et al., 2005). A expressão de RPA1 em células que expressam genes de HPV tem sido analisada. Estudos utilizando imunofluorescência e hibridação in situ em células com DNA de HPV11 e HPV16 mostraram uma reorganização espacial da maquinaria de replicação do DNA do hospedeiro onde se observaram sítios ativos de síntese de DNA onde co localizavam o DNA de HPV, as proteínas virais com E1 e E2 e diferentes fatores celulares, incluindo a proteína RPA1 (Wang et al., 2013; Swindle et al.,1999). No presente estudo observamos que os níveis desta proteína estão aumentados em linhagens derivadas de tumores de colo do útero quando comparadas a queratinócitos normais. Além disso, observamos que o silênciamento deste gene diminui de maneira significativa a proliferação/viabilidade das células SiHa e Hela (figuras 16 e 17). Uma vez que esta proteína tem um papel fundamental em vários processos importantes na manutenção da homeostase da molécula de DNA é possível a que a queda em seus níveis seja crítica em células com elevado metabolismo e taxa de replicação como são as células tumorais.

Outra possibilidade interessante é que a queda na proliferação/viabilidade das células estudadas seja consequência da dependência das células transformadas por HPV de alguns elementos das vias de reparo de dano ao DNA em função de alterações presentes na célula tumoral. O conceito de letalidade sintética surgiu do estudo da genética de leveduras para descrever a interação entre um par de genes distintos que ao serem perdidos de forma individual geram células viáveis, mas que ao serem perdidos de maneira conjunta são letais ou reduzem drasticamente o 
potencial proliferativo da célula. A letalidade sintética pode se estabelecer quando acontecem mutações: em dois genes pertencentes a uma mesma via essencial, em dois genes pertencentes a duas vias paralelas redundantes que levam à síntese de um produto gênico comum e essencial, ou em dois genes de vias de sobrevivência independentes que agem como vias alternativas de salvação na ausência de uma delas. Assim, a célula pode sobreviver quando uma das vias é alterada. Por outro lado, a perda simultânea das duas vias inativa uma função essencial da célula provocando a sua morte (Canaani, 2009).

O conceito de letalidade sintética também pode ser aplicado em situações em que a célula é submetida a outros tipos de estresse, como por exemplo, durante a infecção por um vírus oncogênico. As infecções por HPV de alto risco constituem casos de particular interesse, uma vez que as oncoproteínas E6 e E7 agem em vias de transdução de sinal que estão alteradas na maioria dos tumores sólidos não associados a este vírus, como é o caso das vias reguladas por p53 e pRb. Além disso, estas células carregam uma série de alterações inerentes à atividade dos genes virais. Por exemplo, foi demonstrada a existência de letalidade sintética entre p53 e as quinases PAK3 e SGK2 em células transformadas por HPV (Balwin et al., 2010). Nestas células, as quinases PAK3 e SGK2 foram inativadas por lentivírus que carregavam shRNA específicos. A inativação de p53 foi atingida pela expressão da oncoproteína E6 de HPV16. No momento, não dispomos de dados para provar a existência de letalidade sintética entre RPA1 e algum dos alvos das proteínas virais. No entanto, estamos realizando experimentos nos quais RPA1 será silênciado em QPH que expressam as proteínas E6 ou E7 de HPV16. Acreditamos que os dados gerados ajudarão a determinar se RPA1 está envolvido em uma relação de letalidade sintética em células que expressam genes de HPV e a direcionar nossos estudos na procura do possível parceiro dessa relação.

Interessantemente, vários exemplos de letalidade sintética foram descritos envolvendo genes associados aos diferentes sistemas de reparo de dano ao DNA e para as vias de sinalização reguladas por diferentes genes supressores de tumor. A inativação por mutação somática de um ou mais genes destas classes pode ser detectada na maioria dos tumores (Reinhardt et al., 2009). O primeiro caso descrito 
de letalidade sintética envolvendo genes associados ao reparo do DNA foi o da polimerase Poli(ADP-ribose) (PARP) e os genes de suscetibilidade ao câncer de mama e ovário BRCA1 e BRCA2 (Bryant et al., 2005; Farmer et al., 2005). Contudo, devido à natureza redundante dessas vias, muitos tumores são capazes de reparar de maneira eficiente diferentes lesões no DNA. Assim, os tumores podem se adaptar e sobreviver na presença de uma maquinaria de reparo parcialmente comprometida. No entanto, este fato pode tornar o tumor completamente dependente de vias alternativas de reparo. Assim, os dados obtidos no presente estudo podem contribuir na identificação de genes essências para a sobrevivência de células transformadas por HPV. Finalmente, esta informações podem ser exploradas para desenvolver toxicidade específica para o tumor contribuindo à implementação de novas estratégias terapêuticas de lesões associadas a este vírus. 


\section{CONCLUSÃO}

Nossos dados mostram a existência de alterações importantes no padrão de expressão de genes associados às vias de reparo de dano ao DNA entre queratinócitos normais e linhagens celulares derivadas de tumores de colo do útero.

Os níveis das proteínas LIG1, MRE11, RAD9, SMC1A e TREX1 apresentaram um aumento nas linhagens tumorais quando comparadas a queratinócitos normais ou que expressam genes de HPV.

Observamos um aumento nos níveis das proteínas FEN1, PCNA, RAD51 e RPA1 nas linhagens tumorais e em queratinócitos transduzidos com E6 e E7 de HPV16. Por outro lado, alterações nos níveis destas proteínas não foram observadas em queratinócitos que expressam as proteínas E6 e E7 de HPV11.

O silênciamento da expressão de TREX1 aumentou de maneira significativa a taxa de proliferação de células SiHa. Por outro lado, a inibição de RPA1 inibiu a proliferação/viabilidade das linhagens SiHa e HeLa. 


\section{REFERÊNCIAS ${ }^{1}$}

Abraham RT. Cell cycle checkpoint signaling through the ATM and ATR kinases. Genes Dev. 2001,15: 2177-2196. doi: 10.1101/gad.914401.

Akerman GS, Tolleson WH, Brown KL, Zyzak LL, Mourateva E, Engin TS, Basaraba A, Coker AL, Creek KE, Pirisi L. Human papillomavirus type 16 E6 and E7 cooperate to increase epidermal growth factor receptor (EGFR) mRNA levels, overcoming mechanisms by which excessive EGFR signaling shortens the life span of normal human keratinocytes. Cancer Res. 2001; 61:3837-43.

Alazawi W, Pett M, Strauss S, Moseley R, Gray J, Stanley M, Coleman N. Genomic imbalances in 70 snap-frozen cervical squamous intraepithelial lesions: associations with lesion grade, state of the HPV16 E2 gene and clinical outcome. $\mathrm{Br} \mathrm{J}$ Cancer. 2004; 91:2063-70. doi:10.1038/sj.bjc.6602237

Arias-Pulido H, Narayan G, Vargas H, Mansukhani M, Murty VV. Mapping common deleted regions on $5 \mathrm{p} 15$ in cervical carcinoma and their occurrence in precancerous lesions. Mol Cancer. 2002;1:3. doi:10.1186/1476-4598-1-3

Bachmann A, Hanke B, Zawatzky R, Soto U, van Riggelen J, zur Hausen H, Rösl F.Disturbance of tumor necrosis factor alpha-mediated beta interferon signaling in cervical carcinoma cells. J Virol. 2002 Jan;76(1):280-91.

Bajpai D; Banerjee A; Pathak S; Jain S K; Singh N. Decreased expression of DNA repair genes (XRCC1, ERCC1, ERCC2, and ERCC4) in squamous intraepithelial lesion and invasive squamous cell carcinoma of the cervix. Mol Cell Biochem. 2013 377:45-53.doi: 10.1007/s11010-013-1569-y.

Baldwin A, Grueneberg DA, Hellner K, Sawyer J, Grace M, Li W, Harlow E, Munger K. Kinase requirements in human cells: V. Synthetic lethal interactions between p53 and the protein kinases SGK2 and PAK3. Proc Natl Acad Sci USA. 2010; 107(28):12463-8.

Baldwin A, Li W, Grace M, Pearlberg J, Harlow E, Münger K, Grueneber DA. Kinase requirements in human cells: II. Genetic interaction screens identify kinase requirements following HPV16 E7 expression in cancer cells. PNAS, 2008;105(43):16478-83. doi: 10.1073/pnas.0806195105

Barbosa MS, Edmonds C, Fisher C, Schiller JT, Lowy DR, Vousden KH. The region of the HPV E7 oncoprotein homologous to adenovirus E1a and Sv40 large T antigen contains separate domains for $\mathrm{Rb}$ binding and casein kinase II phosphorylation. EMBO J.1990 Jan; 9(1):153-60.

Boccardo E. HPV-mediated genome instability: at the roots of cervical carcinogenesis. Cytogenet Genome Res. 2010;128(1-3):57-65.

\footnotetext{
${ }^{1}$ De acordo com: International committee of Medical Journal Editors. Uniform requirements for manuscripts submitted to Biomedical Journal.
} 
Bosch FX, Munoz N. The viral etiology of cervical cancer. Virus Res. 2002;89 (2): 183-90,1995.Oncogene. Mar; 2;10(5):927-36.

Boshart M., Boshart M., Gissmann L., Ikenberg H., Kleinheinz A., Scheurlen W., zur Hausen $\mathrm{H}$. A new type of papillomavirus DNA, its presence in genital cancer biopsies and in cell lines derived from cervical cancer. EMBO J. 1984 May;3(5):1151-7.

Bryant HE, Schultz N, Thomas HD, Parker KM, Flower D, Lopez E, Kyle S, Meuth M, Curtin NJ, Helleday T. Specific killing of BRCA2-deficient tumours with inhibitors of poly(ADP-ribose) polymerase. Nature. 2005 Apr;434(7035):913-7. Erratum in: Nature. 2007 May;447(7142):346.

Butz K, Whitaker N, Denk C, Ullmann A, Geisen C, Hoppe-Seyler F. Induction of the p53-target gene GADD45 in HPV-positive cancer cells. Oncogene. 1999 Apr;18(14):2381-6.

Cahill, D. P., K. W. Kinzler, B. Vogelstein, and C. Lengauer. Genetic instability and Darwinian selection in tumours. Trends Cell Biol. Dec.1999;9(12):M57-M60. Doi: 10.1016/S0962-8924(99)01661-X

Canaani D. Methodological approaches in application of synthetic lethality screening towards anticancer therapy. $\mathrm{Br} J$ Cancer. 2009;100(8):1213-8. doi: 10.1038/sj.bjc. 6605000

Cattani P, Hohaus S, Bellacosa A, Genuardi M, Cavallo S, Rovella V, Almadori G, Cadoni G, Galli J, Maurizi M, Fadda G, Neri G. Association between cyclin D1 (CCND1) gene amplification and human papillomavirus infection in human laryngeal squamous cell carcinoma. Clin Cancer Res.1998 Nov;4(9):2585-9.

Chow LT, Broker TR. In vitro experimental systems for HPV: epithelial raft cultures for investigations of viral reproduction and pathogenesis and for genetic analyses of viral proteins and regulatory sequences. Clin Dermatol.1997 Mar-Apr;15(2):217-27. Doi: 10.1016/S0738-081X(97)00069-2

Crook T, Tidy JA, Vousden $\mathrm{KH}$. Degradation of p53 can be targeted by HPV E6 sequences distinct from those required for p53 binding and trans-activation. Cell.1991 Nov;67(3):547-56.

Demers GW, Foster SA, Halbert CL, Galloway DA: Growth arrest by induction of p53 in DNA damaged keratinocytes is bypassed by human papillomavirus $16 \mathrm{E7}$. Proc Natl Acad Sci USA, 91: 4382-4386, 1994.

Doorbar, J. The papillomavirus life cycle. J. Clin. Virol. 2005;32(Suppl 1)S7-S15.

Duensing S, Lee LY, Duensing A, Basile J, Piboonniyom S, Gonzalez S, Crum CP, Munger K.The human papillomavirus type 16 E6 and E7 oncoproteins cooperate to induce mitotic defects and genomic instability by uncoupling centrosome duplication from the cell division cycle. Proc Natl Acad Sci USA. 2000;97(18):10002-7. 
Duensing S, Munger K. The human Papillomavirus type 16 E6 and E7 oncoproteins independently induce numerical and structural chromosome instability. Cancer Res. 2002;62(23):7075-82.

Durst M., Gissmann L., Ikenberg H., Zur Hausen H. A papillomavirus DNA from a cervical carcinoma and its prevalence in cancer biopsy samples from different geographic regions. Proc Natl Acad Sci U S A. 1983 Jun;80(12):3812-5.

Dyson N, Howley PM, Munger K, Harlow E. The human papilloma virus-16 E7 oncoprotein is able to bind to the retinoblastoma gene product. Science.1989;243(4893):934-7. DOI: 10.1126/science.2537532

Farmer H, McCabe N, Lord CJ, Tutt AN, Johnson DA, Richardson TB, Santarosa M, Dillon KJ, Hickson I, Knights C, Martin NM, Jackson SP, Smith GC, Ashworth A. Targeting the DNA repair defect in BRCA mutant cells as a therapeutic strategy. Nature. 2005 Apr; 434(7035):917-21.

Francis DA, Schmid SI, Howley PM. Repression of the integrated papillomavirus E6/E7 promoter is required for growth suppression of cervical cancer cells. J Virol. 2000 Mar;74(6):2679-86.

Gagne SE, Jensen R, Polvi A, Da Costa M, Ginzinger D, Efird JT, Holly EA, Darragh T, Palefsky JM. High-resolution analysis of genomic alterations and human Papillomavirus integration in anal intraepithelial neoplasia. J Acquir Immune Defic Syndr. 2005;40(2):182-9.

Gewin L, and Galloway DA,E box-dependent activation of telomerase by human papillomavirus type $16 \mathrm{E} 6$ does not require induction of c-myc. J Virol. 2001 Aug;75(15):7198-201. doi: 10.1128/JVI.75.15.7198-7201.2001

Giampieri S, Storey A. Repair of UV-induced thymine dimers is compromised in cells expressing the E6 protein from human papillomaviruses types 5 and 18 . Br J Cancer. 2004;90:2203-9. doi:10.1038/sj.bjc.6601829.

Gillespie KA, Mehta KP, Laimins LA, Moody CA. Human papillomaviruses recruit cellular DNA repair and homologous recombination factors to viral replication centers. J Virol. 2012 Sep;86(17):9520-6. DOI: 10.1128/JVI.00247-12.

Guess CJ, McCance JD. Decreased migration of Langerhans precursor-like cells in response to human keratinocytes expressing human papillomavirus type $16 \mathrm{E} 6 / \mathrm{E} 7$ is related to reduced macrophage inflammatory protein-3alpha production. J Virol. 2005 Dec.;79(23): 14852-62.doi: 10.1128/JVI.79.23.14852-14862.

Halbert CL, Demers GW, Galloway DA. The E6 and E7 genes of human papillomavirus type 6 have weak immortalizing activity in human epithelial cells. J Virol.1992;66:2125-34.

Halbert CL, Demers GW, Galloway DA. The E7 gene of human papillomavirus type 16 is sufficient for immortalization of human epithelial cells. J Virol.1991 Jan;65(1):473-8. 
Hasan M, Koch J, Rakheja D, Pattnaik AK, Brugarolas J, Dozmorov I, Levine B, Wakeland EK, Lee-Kirsch MA, Yan N. Trex1 regulates lysosomal biogenesis and interferon-independent activation of antiviral genes. Nat Immunol. 2013 Jan;14(1):6171. doi: $10.1038 /$ ni.2475.

Heilman SA, Nordberg JJ, Liu Y, Sluder G, Chen JJ. Abrogation of the postmitotic checkpoint contributes to polyploidization in human papillomavirus E7-expressing cells. J Virol. 2009;83:2756-64. doi: 10.1128/JVI.02149-08.

Helt AM, Galloway DA. Destabilization of the retinoblastoma tumor suppressor by human papillomavirus type $16 \mathrm{E} 7$ is not sufficient to overcome cell cycle arrest in human keratinocytes. J Virol. 2001;75(15):6737-47. doi: 10.1128/JVI.75.15.67376747.2001.

Howie HL, Katzenellenbogen RA, Galloway DA. Papillomavirus E6 proteins. Virology. 2009; 384(2):324-34. Doi:10.1016/j.virol.2008.11.017.

Howley PM. Lowy DR. Papillomaviruses. In: Knipe DM, Howley PM. Fields Virology. 5. ed. Philadelphia: Lippincot Williams Wilkins; 2007. Cap. 62 p. 2299-354.

IARC Working Group. Human papillomaviruses. IARC Monographs on the evaluation of carcinogenic risk to humans. International Agency for Research on Cancer. Lyon: IARC; 2007;90.

Instituto Nacional do Câncer (INCA). Brasil. Ministério da Saúde. Coordenação de prevenção e Vigilância. Estimativa 2014. Incidência de câncer no Brasil. Rio de Janeiro: $\quad$ INCA; $2014 . \quad 98 \quad$ p. $\quad$ Disponível em: <http://www1.inca.gov.br/vigilancia/incidencia>[Acesso em: 2014 JAN 15].

Kadaja M, Isok-Paas H, Laos T, Ustav E, Ustav M. Mechanism of genomic instability in cells infected with the high-risk human papillomaviruses. PLoS Pathog. 2009 Apr;5(4):e1000397. doi: 10.1371/journal.ppat.1000397.

Kavanagh D, Spitzer D, Kothari PH, Shaikh A, Liszewski MK, Richards A, Atkinson JP. New roles for the major human 3'-5' exonuclease TREX1 in human disease. Cell Cycle. 2008 Jun 15;7(12):1718-25.

Kessis TD, Slebos RJ, Nelson WG, Kastan MB, Plunkett BS, Han SM, Lorincz AT, Hedrick L, Cho KR. Human papillomavirus 16 E6 expression disrupts the p53mediated cellular response to DNA damage. Proc Natl Acad Sci USA.1993; 90:398892.

Lechner MS, Mack DH, Finicle AB, Crook T., Vousden KH, Laimins LA. Human papillomavirus $\mathrm{E} 6$ proteins bind p53 in vivo and abrogate p53-mediated repression of transcription. EMBO J.1992; 11:3045-52.

Lembo D, Donalisio M, Cornaglia M, Azzimonti B, Demurtas A, Landolfo S: Effect of highrisk human papillomavirus oncoproteins on p53R2 gene expression after DNA damage. Virus Res. 2006 Dec;122(1-2):189-93. Doi:10.1016/j.virusres.2006.06.01. 
Lindahl T, Barnes DE, Yang YG, Robins $P$. Biochemical properties of mammalian TREX1 and its association with DNA replication and inherited inflammatory disease. Biochem Soc Trans. 2009 Jun.;37(Pt 3):535-8. doi: 10.1042/BST0370535

Lindahl T. Instability and decay of the primary structure of DNA. Nature.1993 Apr;362(6422):709-15. doi:10.1038/362709a0

Liu X, Han S, Baluda MA, Park N. HPV-16 oncogenes E6 and E7 are mutagenic in normal human oral keratinocytes. Oncogene. 1997 May;14(19): 2347-53.

Liu Y, Heilman SA, Illanes D, Sluder G, Chen JJ. p53-independent abrogation of a postmitotic checkpoint contributes to human papillomavirus E6-induced polyploidy. Cancer Res. 2007 Mar;67(6): 2603-10. doi: 10.1158/0008-5472.CAN-06-3436.

Lowndes NF and Murguia JR. 2000. Sensing and responding to DNA damage.. Curr Opin Genet Dev. 2000 Feb;10(1):17-25. doi:10.1016/S0959-437X(99)00050-7.

Markowitz D, Goff S, Bank A. Construction of a safe and efficient retrovirus packaging cell line. Virology. 1988 Dec;67(2):400-6. Doi:10.1016/00426822(88)90101-8

McLaughlin-Drubin ME, Münger K. The human papillomavirus E7 oncoprotein. Virology. 2009;384(2):335-44. doi: 10.1016/j.virol.2008.10.006

McMurray HR, Nguyen D, Westbrook TF, McAnce DJ: Biology of human papillomaviruses. Int J Exp Pathol. 2001 Feb;82(1):15-33. doi: 10.1046/j.13652613.2001.00177.x

Méhes G, Speich N, Bollmann M, Bollmann R. Chromosomal aberrations accumulate in polyploid cells of high-grade squamous intraepithelial lesions (HSIL). Pathol Oncol Res. 2004;10(3):142-8.

Morita M, Stamp G, Robins P, Dulic A, Rosewell I, Hrivnak G, Daly G, Lindahl T, Barnes DE Gene-targeted mice lacking the Trex1 (DNase III) 3'-->5' DNA exonuclease develop inflammatory myocarditis. Mol Cell Biol. 2004 Aug;24(15):671927.

Munger $\mathrm{K}$, Baldwin A, Edwards $\mathrm{KM}$, et al. Mechanisms of human papillomavirusinduced oncogenesis. J Virol. 2004 Nov;78(21):11451-60. doi: 10.1128/JVI.78.21.11451-11460.2004

Munger K, Phelps WC, Bubb V, Howley PM, Schlegel RJ. The E6 and E7 genes of the human papillomavirus type 16 together are necessary and sufficient for transformation of primary human keratinocytes. J Virol. 1989;63(10):4417-21.

Nees M, Geoghegan JM, Hyman T, Frank S, Miller L, Woodworth CD. Papillomavirus type 16 oncogenes downregulate expression of interferon-responsive genes and upregulate proliferation-associated and NF-kappaB-responsive genes in cervical keratinocytes. J Virol. 2001 May;75(9):4283-96. 
Nees M, Geoghegan JM, Munson P, Prabhu V, Liu Y, Androphy E, Woodworth CD.Human papillomavirus type $16 \mathrm{E} 6$ and E7 proteins inhibit differentiationdependent expression of transforming growth factor-beta2 in cervical keratinocytes. Cancer Res. 2000 Aug; 60(15):4289-98.

Nobel prize "Harald zur Hausen - Facts". Nobelprize.org. Nobel Media AB 2013. [cited 2014 Jan22]Available from: http://www.nobelprize.org/nobel_prizes/medicine/laureates/2008/hausen-facts.html

Pett MR, Alazawi WO, Roberts I, Dowen S, Smith DI, Stanley MA, Coleman N. Acquisition of high-level chromosomal instability is associated with integration of human papillomavirus type 16 in cervical keratinocytes. Cancer Res. 2004;64:135968. doi:10.1158/0008-5472.CAN-03-3214

Pfaffl MW, Horgan GW, Dempfle L. Relative expression software tool (REST) for group-wise comparison and statistical analysis of relative expression results in realtime PCR. Nucleic Acids Res. 2002 May 1;30(9):e36.

Rao PH, Arias-Pulido H, Lu XY, Harris CP, Vargas H, Zhang FF, Narayan G, Schneider A, Terry MB, Murty VV. Chromosomal amplifications, $3 q$ gain and deletions of $2 q 33-q 37$ are the frequent genetic changes in cervical carcinoma. BMC Cancer. 2004; 4(5):1-9. doi: 10.1186/1471-2407-4-5

Reinhardt $\mathrm{HC}$, Jiang $\mathrm{H}$, Hemann MT, Yaffe MB. Exploiting synthetic lethal interactions for targeted cancer therapy. Cell Cycle. 2009 Oct;8(19):3112-9.

Reinson T, Toots M, Kadaja M, Pipitch R, Allik M, Ustav E et al. Engagement of the ATR-dependent DNA damage response at the human papillomavirus 18 replication centers during the initial amplification. J Virol. 2013 Jan;87(2):951-64. doi: 10.1128/JVI.01943-12

Rey $\mathrm{O}$, Lee S, Park NH: Impaired nucleotide excision repair in UV-irradiated human oral keratinocytes immortalized with type 16 human papillomavirus genome. Oncogene. 1999;18(50):6997-7001.

Ronco LV, Karpova AY, Vidal M, Howley PM. Human papillomavirus 16 E6 oncoprotein binds to interferon regulatory factor-3 and inhibits its transcriptional activity. Genes Dev. 1998 Jul 1;12(13):2061-72.

Sakakibara, N, Mitra, R, McBride AA. The papillomavirus E1 helicase activates a cellular DNA damage response in viral replication foci. J Virol. 2011, 85(17); 898195. doi: 10.1128/JVI.00541-11

Sancar A, Lindsey-Boltz LA, Unsal-Kaçmaz K, Linn S. Molecular mechanisms of mammalian DNA repair and the DNA damage checkpoints. Annu Rev Biochem. 2004;73:39-85. doi: 10.1146/annurev.biochem.73.011303.073723

Scheffner M Werness BA, Huibregtse JM, Levine AJ, Howley PM. The E6 oncoprotein encoded by human papillomavirus types 16 and 18 promotes the degradation of p53. Cell.1990 Dec;63(6):1129-36.doi:10.1016/0092-8674(90)90409-8 
Scheffner M, Münger K, Byrne JC, Howley PM.The state of the p53 and retinoblastoma genes in human cervical carcinoma cell lines. Proc Natl Acad Sci U S A.1991 Jul;88(13):5523-7.

Sherman L, Itzhaki H, Jackman A, Chen JJ, Koval D, Schlegel R. Inhibition of serumand calcium-induced terminal differentiation of human keratinocytes by HPV 16 E6: study of the association with p53 degradation, inhibition of p53 transactivation, and binding to E6BP. Virology. 2002;292:309-320.

Shin KH, Ahn JH, Kang MK, Lim PK, Yip FK, Baluda MA, Park NH. HPV-16 E6 oncoprotein impairs the fidelity of DNA end-joining via p53-dependent and independent pathways. Int J Oncol. 2006;28:209-15.

Sokolova I, Algeciras-Schimnich A, Song M, Sitailo S, Policht F, Kipp BR, Voss JS, Halling KC, Ruth A, King W, Underwood D, Brainard J, Morrison L. Chromosomal biomarkers for detection of human Papillomavirus associated genomic instability in epithelial cells of cervical cytology specimens. J Mol Diagn. 2007; 9:604-11.

Song S, Gulliver GA, Lambert PF. Human Papillomavirus type 16 E6 and E7 oncogenes abrogate radiation-induced DNA damage responses in vivo through p53dependent and p53-independent pathways. Proc Natl Acad Sci USA.1998;95:2290-5.

Southern SA, Noya F, Meyers C, Broker TR, Chow LT, Herrington CS. Tetrasomy is induced by human papillomavirus type 18 E7 gene expression in keratinocyte raft cultures. Cancer Res. 2001 June;61:4858-63.

Srivenugopal KS, Ali-Osman $\mathrm{F}$. The DNA repair protein, $\mathrm{O}(6)$-methylguanine-DNA methyltransferase is a proteolytic target for the E6 human papillomavirus oncoprotein. Oncogene. 2002; 21:5940-5.

Srivenugopal KS, Ali-Osman F. The DNA repair protein, O(6)-methylguanine-DNA methyltransferase is a proteolytic target for the E6 human papillomavirus oncoprotein. Oncogene. 2002; 21:5940-5.

Stanley MA, Browne HM, Appleby M, Minson AC. Properties of a non-tumorigenic human cervical keratinocyte cell line. Int J Cancer. 1989;43(4):672-6.

Steenbergen RD, Hermsen MA, Walboomers JM, Joenje H, Arwert F, Meijer CJ, Snijders PJ. Integrated human papillomavirus type 16 and loss of heterozygosity at $11 q 22$ and $18 q 21$ in an oral carcinoma and its derivative cell line. Cancer Res.1995;55:5465-71.

Sulli G., Micco R. D.; Fagagna F. A. Crosstalk between chromatin state and DNA damage response in cellular senescence and cancer. 2012. Nat Rev Cancer. 2012 Oct;12(10):709-20. doi: 10.1038/nrc3344.

Swindle CS, Zou N, Van Tine BA, Shaw GM, Engler JA, Chow LT. Human papillomavirus DNA replication compartments in a transient DNA replication system. J Virol. 1999 Feb;73(2):1001-9. 
Therrien JP, Drouin R, Baril C, Drobetsky EA. Human cells compromised for p53 function exhibit defective global and transcriptioncoupled nucleotide excision repair, whereas cells compromised for $\mathrm{pRb}$ function are defective only in global repair. Proc Natl Acad Sci USA.1999 Dec; 96(26):15038-43.

Thomas JT, Laimins LA. Human papillomavirus oncoproteins E6 and E7 independently abrogate the mitotic spindle checkpoint. J Virol.1998 Feb;72(2):11317.

TIsty TD, Briot A, Gualberto A, Hall I, Hess S, Hixon M, Kuppuswamy D, Romanov S, Sage M and White A. Genomic instability and cancer. Mutat Res.1995,3371: 1-7.

Tota JE, Chevarie-Davis M, Richardson LA, Devries M, Franco EL. Epidemiology and burden of HPV infection and related diseases: implications for prevention strategies. Prev Med. 2011 Oct;53 Suppl 1:S12-21. doi:10.1016/j.ypmed.2011.08.017.

Wallace NA, Galloway DA. Manipulation of cellular DNA damage repair machinery facilitates propagation of human papillomaviruses. Semin Cancer Biol. 2014; [Epub ahead of print]. doi: org/10.1016/j.semcancer.2013.12.003.

Wang X, Helfer CM, Pancholi N, Bradner JE, You J. Recruitment of Brd4 to the human papillomavirus type 16 DNA replication complex is essential for replication of viral DNA. J Virol. 2013 Apr;87(7):3871-84. doi: 10.1128/JVI.03068-12.

Wang Y, Putnam CD, Kane MF, et al. Mutation in Rpa1 results in defective DNA double-strand break repair, chromosomal instability and cancer in mice. Nat Genet. 2005 Jul;37(7):750-5. doi:10.1038/ng1587.

Wang Z, Rao DD, Senzer N, Nemunaitis J. RNA Interference and cancer therapy. Pharm Res. 2011 Dec, 28(12):2983-95. Doi: 10.1007/s11095-011-0604-5.

Watanabe S, Kanda T, Yoshiike K. Human papillomavirus type 16 transformation of primary human embryonic fibroblasts requires expression of open reading frames E6 and E7. J Virol. 1989 Feb;63(2):965-9.

Wilson VG, West M, Woytek K, Rangasamy D. Papillomavirus E1 proteins: form, function, and features. Virus Genes.2002 Jun;24(3):275-90.

Wilting SM, Smeets SJ, Snijders PJ, van Wieringen WN, van de Wiel MA, Meijer GA, Ylstra B, Leemans CR, Meijer CJ, Brakenhoff RH, Braakhuis BJ, Steenbergen RD. Genomic profiling identifies common HPV-associated chromosomal alterations in squamous cell carcinomas of cervix and head and neck. BMC Med Genomics, 2009; 2:32. doi: 10.1186/1755-8794-2-32.

Wilting SM, Snijders PJ, Meijer GA, Ylstra B, van den ljssel PR, Snijders AM, Albertson DG, Coffa J, Schouten JP, van de Wiel MA, Meijer CJ, Steenbergen RD. Increased gene copy numbers at chromosome $20 q$ are frequent in both squamous cell carcinomas and adenocarcinomas of the cervix. J Pathol. 2006 Jun;209(2):22030. doi: 10.1002/path.1966 
Wilting SM, Steenbergen RD, Tijssen M, van Wieringen WN, Helmerhorst TJ, van Kemenade FJ, Bleeker MC, van de Wiel MA, Carvalho B, Meijer GA, Ylstra B, Meijer CJ, Snijders PJ. Chromosomal signatures of a subset of highgrade premalignant cervical lesions closely resemble invasive carcinomas. Cancer Res. 2009 b;69:64755. doi: 10.1158/0008-5472.CAN-08-2478.

Wistuba II, Montellano FD, Milchgrub S, Virmani AK, Behrens C, Chen H, Ahmadian M, Nowak JA, Muller C, Minna JD, Gazdar AF. Deletions of chromosome 3p are frequent and early events in the pathogenesis of uterine cervical carcinoma. Cancer Res.1997;57: 3154-8.

Yan N, Lieberman J. Gaining a foothold: how HIV avoids innate immune recognition. Curr Opin Immunol. 2011 Feb;23(1):21-28. doi: 10.1016/j.coi.2010.11.004.

Yan N, Regalado-Magdos AD, Stiggelbout B, Lee-Kirsch MA, Lieberman J.The cytosolic exonuclease TREX1 inhibits the innate immune response to human immunodeficiency virus type 1. Nat Immunol. Nov.2010;11(11):1005-13. doi:10.1038/ni.1941.

Yang J, Yu Y, Hamrick HE and Duerksen-Hughes PJ. 2003. ATM, ATR and DNA-PK: initiators of the cellular genotoxic stress responses. Carcinogenesis. 2003 Oct;24(10):1571-80. doi: 10.1093/carcin/bgg137.

Zhou BB, Elledge SJ. The DNA damage response: putting checkpoints in perspective. Nature. 2000 Nov 23;408(6811):433-9. doi:10.1038/35044005.

Zur Hausen $\mathrm{H}$. Papillomavirus infections a major cause of human cancers. Biochim Biophys Acta. 1996 Oct 9;1288(2):F55-78. 